\title{
SOBRE A CONSPICUIDADE, LEGIBILIDADE E RETRORREFLETIVIDADE DAS PLACAS DE SINALIZAÇÃo VIÁRIA
}

Felipe Bosco Castilho

Dissertação apresentada à Escola de Engenharia de São Carlos da Universidade de São Paulo, como parte dos requisitos para obtenção do título de Mestre em Engenharia de Transportes.

ORIENTADOR: Prof. Dr. Antonio Clóvis Pinto

Ferraz

São Carlos

2009 
Aos meus avós,

Tidalha Pazotti Bosco e Agileo Bosco (in memorian), por todo o amor, incentivo e apoio. 


\section{AGRADECIMENTOS}

A Deus, por ter aberto as portas, mostrado o caminho e me acolhido nos momentos difíceis.

Ao professor Dr. Antonio Clóvis Pinto Ferraz (Coca), pela orientação, apoio e amizade.

Aos meus pais, Elisabeth e Celso, meus exemplos de vida.

A minha irmã Juliana e meu cunhado Renato, pelo incentivo.

A minha esposa Roberta, pelo carinho e força.

Aos professores e funcionários da Área de Pós-Graduação em Transportes, pelo apoio e amizade.

A 3M do Brasil, por ter cedido o seu laboratório para realização dos experimentos.

A todos aqueles que foram "sujeitos" nos experimentos - sem eles a realização desta pesquisa não teria sido possível. 
"Nada melhor do que um sonho para criar o futuro."

Victor Hugo 


\section{RESUMO}

CASTILHO, F. B. Sobre a conspicuidade, legibilidade e retrorrefletividade das placas de sinalização viária. Dissertação (mestrado) - Escola de Engenharia de São Carlos, Universidade de São Paulo, São Carlos, 2009.

Neste trabalho é analisada a retrorrefletividade (capacidade de um material permitir a visualização e a leitura de informações quando iluminadas pelo farol de um veículo), a conspicuidade (facilidade de chamar a atenção) e a legibilidade (facilidade de leitura de símbolos e palavras impressos) de placas de sinalização vertical de trânsito. A análise da retrorrefletividade foi feita mediante medições em laboratório com os materiais retrorrefletivos mais comumente utilizados na sinalização viária. A conspicuidade e a legibilidade foram analisadas em função do ambiente no qual está inserida a sinalização e o tipo de material retrorrefletivo utilizado. Considerando o fato de que as placas devem ter desempenho satisfatório tanto durante o dia como à noite, a conclusão é que as placas sem material refletivo não são recomendadas. Do ponto de vista estritamente técnico, as placas confeccionadas com materiais de maior retrorrefletividade são as mais indicadas. Cabe observar, no entanto, que os tamanhos das amostras utilizadas na elaboração dos experimentos sobre a conspicuidade e legibilidade não apresentam representatividade estatística em nível de significância adequado; razão pela qual os resultados obtidos devem ser vistos apenas como sinalizadores de tendências.

Palavras-chave: sinalização, retrorrefletividade, conspicuidade, legibilidade, segurança viária. 


\begin{abstract}
CASTILHO, F. B. Study about conspicuity, legibility and retroreflectivity in road signs. Dissertation (master) - Escola de Engenharia de São Carlos, Universidade de São Paulo, São Carlos, 2009.

In this dissertation is analyzed the retroreflectivity (ability of a material to allow viewing and reading information when illuminated by the vehicle headlamp), the conspicuity (facility to get attention) and legibility (readability of printed words and symbols) plates in traffic sign. The analysis of retroreflection was made by laboratory measurements with retroreflective material most commonly used in road marking. Conspicuity and legibility were analyzed according to the environment the signal is inserted and the type of retroreflective material used. Considering the fact that the sign must have a satisfactory performance both during day and night, the conclusion is that the signs without reflective material are not recommended. From a strictly technical, the signs that use grater reflective material are the most suitable. It should be noted, however, that the samples sizes used in the experiments on the conspicuity and readability do not have a statistical significance level appropriate, and the results should be viewed only as trends indicators.
\end{abstract}

Keywords: signing, retrorreflectivity, conspicuity, legibility, traffic safety. 


\section{SUMÁRIO}

1. INTRODUÇÃ̃O ............................................. 01

1.1 Histórico e legislação ................................................. 01

1.2 Acidentes de trânsito ............................................................. 03

1.3 Custos dos acidentes de trânsito ............................................... 06

1.4 Visão sistêmica da segurança viária .......................................... 08

1.5 Objetivo do trabalho ............................................................ 10

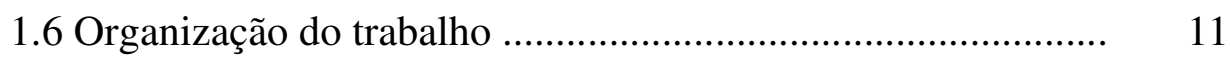

2. SINALIZAÇÃ̃ DE TRÂNSITO ............................ 12

2.1 Considerações iniciais .............................................. 12

2.2 Tipos de sinalização de trânsito ................................................ 13

2.2.1 Sinalização vertical ................................................... 13

- Sinalização de regulamentação ............................. 14

- Sinalização de advertência ................................... 20

- Sinalização de indicação ......................................... 27

2.2.2 Sinalização horizontal .............................................. 31

2.2.3 Dispositivos auxiliares ............................................ $\quad 34$

2.2.4 Sinalização semafórica ............................................. $\quad 35$

2.2.5 Sinalização de obras ................................................. 36

2.2.6 Gestos ................................................................ 37

2.2.7 Sinais sonoros ………………………………...... 39

3. ESTUDOS E NORMAS RELEVANTES SOBRE

SINALIZAÇÃO VIÁRIA ................................................................ 40

4. MÉTODO DE COMPARAÇÃO AOS PARES DA

PSICOFÍSICA ............................................................... 52

4.1 Psicofísica ...................................................................... 52

4.2 Método de Comparação aos Pares .......................................... 53

5. EXPERIMENTOS REALIZADOS ............................ 56

5.1 Local dos experimentos ............................................. 56

5.2 Materiais utilizados ......................................................... 58 
Placas de regulamentação ................................................ $\quad 58$

Placas de indicação de localidade ....................................... $\quad 59$

Equipamento de medição de retrorrefletividade ................ 59

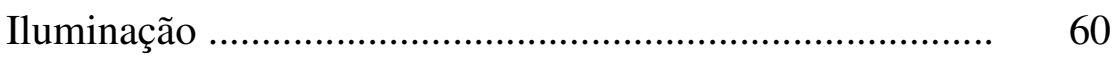

5.3 Descrição dos experimentos ..................................................... 60

\section{APRESENTAÇÃO E ANÁLISE DOS RESULTADOS} OBTIDOS

6.1 Avaliação da Conspicuidade e Legibilidade da placa de regulamentação (experimento 1) .................................................. 64

6.1.1 Avaliação da Conspicuidade .................................... 64

6.1.2 Avaliação da Legibilidade ........................................ 68

6.2 Avaliação da Conspicuidade e Legibilidade da placa de indicação de localidade (experimento 2) ......................................

6.2.1 Avaliação da Conspicuidade ...................................... 72

6.2.2 Avaliação da Legibilidade ........................................ $\quad 76$

6.3 Avaliação da Retrorrefletividade (experimento 3) ................... 80

7. CONCLUSÕES ......................................................... 83

7.1 Sobre as placas de regulamentação ........................................... 83

7.2 Sobre as placas de indicação de localidade .............................. $\quad 86$

7.3 Observações gerais ............................................................... 89

REFERÊNCIAS BIBLIOGRAFICAS .............................. 91

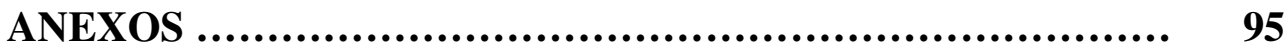

Anexo 1 - Avaliação da conspicuidade e legibilidade das

placas de regulamentação ............................................................ 95

Anexo 2 - Avaliação da conspicuidade e legibilidade das

placas de indicação de localidade .................................................. 97

Anexo 3 - Medida da retrorrefletividade das placas de regulamentação e indicativa de localidade 


\section{LISTA DE FIGURAS}

Figura 1.1 - Severidade dos acidentes de trânsito .................................. 06

Figura 2.1 - Conjunto de sinais de regulamentação ................................. 15

Figura 2.2 - Características dos sinais de regulamentação ..................... 16

Figura 2.3 - Posicionamento em relação ao sentido de fluxo de tráfego. 18

Figura 2.4 - Posicionamento básico de placas em vias urbanas ............ 19

Figura 2.5 - Posicionamento básico de placas em vias rurais ................ 19

Figura 2.6 - Exemplo de localização do sinal de regulamentação R1 .... 20

Figura 2.7 - Conjunto de sinais de advertência ...................................... 21

Figura 2.8 - Características dos sinais de advertência ........................... 22

Figura 2.9 - Visualização de uma placa em tempo real .......................... 24

Figura 2.10 - Exemplo de localização do sinal de advertência A3 e

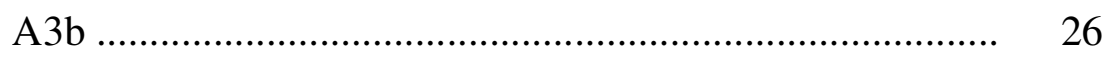

Figura 2.11 - Exemplo de localização do sinal de advertência A18 ........ 26

Figura 2.12 - Exemplo de localização do sinal de advertência A33b ...... 26

Figura 2.13 - Sinalização de indicação de rodovias e estradas ................ 27

Figura 2.14 - Identificação de municípios ................................................... 27

Figura 2.15 - Identificação de regiões de interesse e logradouros .......... 27

Figura 2.16 - Identificação nominal de pontes, viadutos, túneis e passarelas ............................................................. 28

Figura 2.17 - Identificação quilométrica .................................................. 28

Figura 2.18 - Identificação de limite de município .................................... 28

Figura 2.19 - Placa de pedágio .............................................................. 28

Figura 2.20 - Placas indicativas de sentido ............................................ 28

Figura 2.21 - Placas indicativas de distância ........................................... 29

Figura 2.22 - Placas diagramadas ......................................................... 29

Figura 2.23 - Placas Educativas ............................................................ 29

Figura 2.24 - Placas serviços auxiliares (condutores) ............................... 29

Figura 2.25 - Placas serviços auxiliares (pedestres) ………………….. $\quad 30$

Figura 2.26 - Placa de atrativo turístico .................................................. 30 
Figura 2.27 - Placa de sentido de atrativo turístico .................................. 30

Figura 2.28 - Placa de distância de atrativo turístico ............................... 30

Figura 2.29 - Aproximação de obras de arte ............................................ 33

Figura 2.30 - Distância de visibilidade de ultrapassagem ....................... 33

Figura 2.31 - Exemplo de ciclo faixa ………………………………..... 33

Figura 2.32 - Exemplo de parada de veículos específicos ...................... 34

Figura 2.33 - Exemplos de dispositivos auxiliares ................................... 35

Figura 2.34 - Exemplo de semáforo de regulamentação .......................... 35

Figura 2.35 - Exemplo de semáforo de advertência ................................ 36

Figura 2.36 - Exemplo de placas de sinalização de obras ........................ 36

Figura 3.1 - Explicação esquemática dos componentes que afetam a legibilidade das placas verticais de trânsito ......................... 41

Figura 3.2 - Medições de candelas de lâmpadas ...................................... 50

Figura 3.3 - Performance do sinal x posicionamento ............................... 51

Figura 5.1 - Foto do local do experimento ………………………….... 57

Figura 5.2 - Foto do local onde eram observados os experimentos ....... 57

Figura 5.3 - Modelo de placa de regulamentação utilizada ...................... 58

Figura 5.4 - Modelo de placa de indicação de localidade utilizada ......... 59

Figura 5.5 - Foto do aparelho de medição de retrorrefletividade ............ 60

Figura 7.1 - Gráficos dos resultados obtidos para a placa de regulamentação .............................................................. 84

Figura 7.2 - Gráficos dos resultados obtidos para a placa de indicação de localidade ................................................................. 87

Figura 7.3 - Gráfico com o custo das placas ............................................. 89 


\section{LISTA DE TABELAS}

Tabela 1.1 - Taxas de motorização e mortalidade no trânsito em alguns países

Tabela 1.2 - Custo dos acidentes de trânsito no Brasil atualizado para junho de 2008

Tabela 1.3 - Versão adaptada da matriz de Haddon

Tabela 2.1 - Dimensões mínimas e recomendadas para sinais circulares

Tabela 2.2 - Dimensões mínimas e recomendadas - sinais de forma

$$
\text { octógona - R1 }
$$

Tabela 2.3 - Dimensões mínimas e recomendadas - sinais de forma

$$
\text { triangular }-\mathrm{R} 2 \text {. }
$$

Tabela 2.4 - Dimensões mínimas - sinais de forma quadrada

Tabela 2.5 - Dimensões mínimas - sinais de forma retangular

Tabela 2.6 - Dimensões mínimas - Cruz de Santo André - A41

Tabela 2.7 - Distância mínima de visibilidade

Tabela 2.8 - Distância mínima de desaceleração e/ou manobra 25

Tabela 2.9 - Gestos dos condutores

Tabela 2.10 - Gestos das autoridades de trânsito

Tabela 2.11 - Sinais sonoros

Tabela 3.1 - Variáveis relacionadas à conspicuidade e legibilidade de um sinal vertical de trânsito

Tabela 3.2 - Valores mínimos de retrorrefletividade dos sinais verticais de trânsito

Tabela 3.3 - Tipos de materiais retrorrefletivos dos sinais verticais de trânsito

Tabela 3.4 - Retrorrefletividade mínima inicial das películas de sinalização viária

Tabela 4.1 - Escolhas realizadas pelos estudantes no experimento dos carros 
Tabela 4.2 - Percentuais de escolha dos carros

Tabela 4.3 - Escores z correspondentes aos percentuais obtidos no exemplo dos carros .................................................. 55

Tabela 4.4 - Escores z médios, ajustados e ordenados ................... 55

Tabela 5.1 - Tipos de materiais das placas de regulamentação ........... 58

Tabela 5.2 - Tipos de materiais das placas de indicação de localidade... 59

Tabela 6.1 - Matriz de indicações para o período diurno .................. 64

Tabela 6.2 - Proporções médias de indicações para o período diurno ..... 64

Tabela 6.3 - Escores z médio derivados da matriz de proporções médias para o período diurno ........................... 65

Tabela 6.4 - Matriz de indicações para o período noturno ................ 66

Tabela 6.5 - Proporções médias de indicações para o período noturno .. 66

Tabela 6.6 - Escores z médio derivados da matriz de proporções médias para o período noturno .......................... 66

Tabela 6.7 - Matriz de indicações para o período noturno com iluminação 67

Tabela 6.8 - Proporções médias de indicações para o período noturno com iluminação

Tabela 6.9 - Escores z médio derivados da matriz de proporções médias para o período noturno com iluminação ............ 67

Tabela 6.10 - Matriz de indicações para o período diurno ................... 68

Tabela 6.11 - Proporções médias de indicações para o período diurno ... 68

Tabela 6.12 - Escores z médio derivados da matriz de proporções médias para o período diurno .............................. 69

Tabela 6.13 - Matriz de indicações para o período noturno ................ 69

Tabela 6.14 - Proporções médias de indicações para o período noturno.. $\quad 70$

Tabela 6.15 - Escores z médio derivados da matriz de proporções médias para o período noturno

Tabela 6.16 - Matriz de indicações para o período noturno com iluminação 
Tabela 6.17 - Proporções médias de indicações para o período noturno com iluminação

Tabela 6.18 - Escores z médio derivados da matriz de proporções médias para o período noturno com iluminação .............. 71

Tabela 6.19 - Matriz de indicações para o período diurno ..................... 72

Tabela 6.20 - Proporções médias de indicações para o período diurno ... 72

Tabela 6.21 - Escores z médio derivados da matriz de proporções médias para o período diurno ............................... 73

Tabela 6.22 - Matriz de indicações para o período noturno ..................... 74

Tabela 6.23 - Proporções médias de indicações para o período noturno ... 74

Tabela 6.24 - Escores z médio derivados da matriz de proporções médias para o período noturno .............................. 74

Tabela 6.25 - Matriz de indicações para o período noturno com iluminação 75

Tabela 6.26 - Proporções médias de indicações para o período noturno com iluminação 75

Tabela 6.27 - Escores z médio derivados da matriz de proporções médias para o período noturno com iluminação 75

Tabela 6.28 - Matriz de indicações para o período diurno ...................... 76

Tabela 6.29 - Proporções médias de indicações para o período diurno ... 76

Tabela 6.30 - Escores z médio derivados da matriz de proporções médias para o período diurno ............................. 76

Tabela 6.31 - Matriz de indicações para o período noturno …………..... 77

Tabela 6.32 - Proporções médias de indicações para o período noturno .. 77

Tabela 6.33 - Escores z médio derivados da matriz de proporções médias para o período noturno .............................. 78

Tabela 6.34 - Matriz de indicações para o período noturno com iluminação

Tabela 6.35 - Proporções médias de indicações para o período noturno com iluminação 
Tabela 6.36 - Escores z médio derivados da matriz de proporções médias para o período noturno com iluminação............. 79

Tabela 6.37 - Valores de retrorrefletividade ........................... 80

Tabela 6.38 - Valores de retrorrefletividade .......................... 81

Tabela 7.1 - Síntese dos resultados para a placa de regulamentação

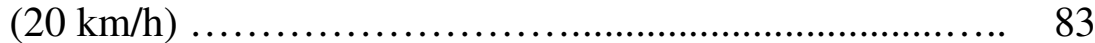

Tabela 7.2 - Síntese dos resultados para a placa de indicação de localidade (palavra Fórum) ........................... 86 


\section{LISTA DE ABREVIATURAS E SIGLAS}

$\begin{array}{ll}\text { ABNT } & \text { - Associação Brasileira de Normas Técnicas } \\ \text { CET } & \text { - Companhia de Engenharia de Tráfego } \\ \text { CONTRAN } & \text { - Conselho Nacional de Trânsito } \\ \text { CTB } & \text { - Código de Trânsito Brasileiro } \\ \text { DENATRAN } & \text { - Departamento Nacional de Trânsito } \\ \text { DER } & \text { - Departamento de Estradas de Rodagem } \\ \text { DNER } & \text { - Departamento Nacional de Estradas de Rodagem } \\ \text { FHWA } & \text { - Federal Highway Administration } \\ \text { GRSP } & \text { - Global Road Safety Partnership } \\ \text { IPEA } & \text { - Instituto de Pesquisa Econômica Aplicada } \\ \text { ONU } & \text { - Organização das Nações Unidas } \\ \text { OMS } & \text { - Organização Mundial da Saúde }\end{array}$




\section{1 \\ INTRODUÇÃO}

\subsection{HISTÓRICO E LEGISLAÇÃO}

Desde a pré-história o homem já adotava um padrão de sinalização quando indicava o sentido de direção com pegadas deixadas no solo, ou com marcas em troncos de árvores ou rochas através de figuras feitas com as palmas das mãos. São os primeiros registros de sinalização que se tem conhecimento. Esses sinais indicavam os caminhos percorridos pelos seres pré-históricos, que tinham vida nômade. Nesse período as marcas no chão deixadas pelos animais também serviam de guia para locomoção e identificação.

De acordo com Moreira e Menegon (2003), registros históricos apontam que os egípcios faziam uso de misturas de resinas, pigmentos e areias para sinalizar horizontalmente suas estradas. Os romanos colocavam tijolos ou pedras no centro das estradas para manter as carruagens em sua mão de direção e surgiram as primeiras placas indicando as distâncias das mais variadas regiões até Roma, por ser esta a principal aglomeração urbana da época. Os Incas e os Astecas chegaram a sinalizar, com setas e outros sinais, a superfície de suas estradas.

Conforme Moraes (2002), entre o final do século XIX e o início do século XX, o automóvel conquistou a Europa e surgiu, então, a necessidade de se organizar o tráfego de veículos e pedestres, através de um sistema consistente de sinalização. Surge então, em 1903, o "Motorcar Act", que descrevia as regras para sinalização de tráfego na Inglaterra.

Desde 1907, na Europa e nos Estados Unidos, o Automóvel Clube e o Touring começaram a solicitar dos governos uma regulamentação dos sinais de 
trânsito existentes. Uma tentativa de unificação dos sinais ocorreu em 1927, quando Otto Neurath, em Viena, criou uma linguagem figurativa internacional, baseada em pictogramas do arquivo de informações culturais.

A partir de 1950, a Organização das Nações Unidas (ONU) promoveu reuniões na tentativa de unificar o sistema simbólico europeu com mensagens escritas. Em 1952, durante a Sexta Sessão da Comissão de Transportes e Comunicação da ONU, foi elaborado um Sistema Uniforme de Sinais de Trânsito (Convenção sobre Sinalização Viária de Draft), que introduzia modificações no sistema europeu e o conciliava com o sistema americano.

Posteriormente, em Viena, no ano de 1968, a ONU promoveu uma nova Conferência Internacional, mantendo oficialmente o sistema Draft, utilizado até hoje nos países agregados (171 países). Este evento ficou mundialmente conhecido como convenção de Viena.

Fontana (2005) coloca que a sinalização de trânsito deve obedecer a certos padrões universais e nacionais para que seja compreendida por pessoas de outros países, outros estados e outras cidades. Aliás, é de suma importância que a sinalização seja reconhecida e compreendida por todo usuário para que surta o efeito desejável.

Além dos documentos oficiais, alguns manuais, devido ao seu alto padrão técnico, são referências para projetos de sinalização, tornando-se assim um dos principais documentos da área. Dentre eles, podem ser citados:

- Manuais da Companhia de Engenharia de Tráfego da cidade de São Paulo, CET/SP, para sinalização urbana.

- Manuais do Departamento Nacional de Estradas de Rodagem, DNER, para a sinalização de rodovias.

- Manuais dos Departamentos Estaduais de Rodovias, DER's, onde podemos citar os manuais atualizados do DER-SP (2006). 
No Brasil, no que se refere à sinalização de trânsito atualmente estão em vigor os seguintes documentos oficiais:

- Lei no 9.503, de 23/09/1997, que aprovou o Atual Código de Trânsito Brasileiro.

- Resolução CONTRAN no 160 , de 22/04/2004, que aprovou o Anexo II do Código de Trânsito Brasileiro.

- Resolução CONTRAN no 180 , de 26/08/2005, que aprovou o Volume I Sinalização Vertical de Regulamentação, do Manual Brasileiro de Sinalização de Trânsito.

- Resolução CONTRAN no 236, de 11/05/2007, que aprovou o Volume IV Sinalização Horizontal, do Manual Brasileiro de Sinalização de Trânsito.

- Resolução CONTRAN no 243, de 22/06/2007, que aprovou o Volume II Sinalização Vertical de Advertência, do Manual Brasileiro de Sinalização de Trânsito.

\subsection{ACIDENTES DE TRÂNSITO}

Assume-se que acidente é um evento independente do desejo do homem, causado por uma força externa, alheia, que atua subitamente (de forma inesperada) e deixa ferimentos no corpo e na mente. Alternativamente, pode-se considerar um acidente um evento não intencional que produz ferimentos ou danos. Acidente de trânsito é todo acidente com veículo ocorrido na via pública.

Os acidentes de trânsito têm causado verdadeiras chacinas em todo o mundo. De acordo com a Organização Mundial da Saúde - OMS (2004), os acidentes de trânsito provocam, anualmente, cerca de 1,2 milhões de mortes no mundo e entre 20 e 50 milhões de feridos - muitos com seqüelas permanentes. 
A previsão da OMS (2004) é ainda mais alarmante, pois ela estima que esses números vão crescer cerca de $67 \%$ até o ano de 2020, com um crescimento de $83 \%$ nos países não desenvolvidos e em desenvolvimento e uma redução de $27 \%$ nas nações desenvolvidas. Ainda de acordo com a OMS (2004), os países não desenvolvidos e em desenvolvimento têm apenas $20 \%$ dos carros do mundo, mas respondem a cerca de $90 \%$ das mortes no trânsito.

Segundo Global Road Safety Partnership - GRSP (2005): “Com mais de 1 milhão de pessoas mortas e mais de 20 milhões de feridos em acidentes de trânsito a cada ano, a segurança no trânsito é um problema de proporções astronômicas. Mais de $75 \%$ das fatalidades ocorrem em países não desenvolvidos e em desenvolvimento, mesmo representando apenas $32 \%$ do total de veículos no mundo."

No Brasil, Ferraz et al. (2008) apontam os seguintes números anuais redondos relativos à acidentalidade viária no ano de 2005: 36 mil mortes, 515 mil feridos (cerca de 100 mil ficando com lesões permanentes, alguns com deficiência física ou mental, ou seqüelas psicológicas graves, que impedem uma vida normal), 385 mil acidentes com vítimas ( $82 \%$ nas cidades e 18\% nas rodovias), 1 milhão de acidentes, 208 acidentes com vítimas por 100 mil habitantes, 91 acidentes com vítimas por 10 mil veículos, 279 vítimas por 100 mil habitantes, 122 vítimas por 10 mil veículos, 19 mortes por 100 mil habitantes e 85 mortes por 10 mil veículos.

A comparação dos índices de mortalidade no trânsito no Brasil com a de alguns países mais desenvolvidos, conforme dados da Tabela 1.1, indica a gravidade do problema da acidentalidade viária no país. A relação entre o número de mortes e a frota de veículos é, no país, mais de 10 vezes superior a da Suíça e Suécia; mais de 8 vezes a do Japão, Alemanha e Grã-Bretanha; mais de 5 vezes a da França e Canadá; e mais de 4 vezes a dos Estados Unidos. 
Tabela 1.1 - Taxas de motorização e de mortalidade no trânsito em alguns países

\begin{tabular}{|c|c|c|c|c|}
\hline País & $\begin{array}{c}\text { Taxa de } \\
\text { motorização } \\
\text { (veíc/100 hab }\end{array}$ & $\begin{array}{c}\text { Taxa de mortalidade } \\
\text { (mortes/100 mil } \\
\text { habitantes/ano }\end{array}$ & $\begin{array}{c}\text { Taxa de mortalidade } \\
\text { (mortes/100 mil } \\
\text { veículos/ano) }\end{array}$ & $\begin{array}{c}\text { Relação mortes/veículo no } \\
\text { Brasil e nos outros países }\end{array}$ \\
\hline Suíça & 68,5 & 5,0 & 7,3 & 11,6 \\
\hline Suécia & 57,5 & 4,9 & 8,5 & 10,0 \\
\hline Japão & 64,8 & 5,7 & 8,8 & 9,7 \\
\hline Alemanha & 66,6 & 6,2 & 9,3 & 9,1 \\
\hline Grã-Bretanha & 56,5 & 5,4 & 9,6 & 8,9 \\
\hline França & 60,9 & 7,7 & 12,6 & 6,7 \\
\hline Canadá & 62,4 & 9,1 & 14,6 & 5,8 \\
\hline Estados Unidos & 82,9 & 14,7 & 17,7 & 4,8 \\
\hline Polônia & 47,3 & 13,8 & 29,2 & 2,9 \\
\hline Hungria & 34,2 & 12,7 & 37,1 & 1,0 \\
\hline Brasil & 22,8 & 19,4 & 85,0 & $1 / 1,8$ \\
\hline Cazaquistão & 9,4 & 14,5 & 154,2 & $1 / 3,2$ \\
\hline Colômbia & 6,3 & 16,8 & 268,1 & $1 / 14,7$ \\
\hline Bangladesh & 0,22 & 2,8 & 1249,3 & $1 / 18,3$ \\
\hline Etiópia & 0,17 & 2,6 & 1553,2 & \\
\hline
\end{tabular}

Fonte: Ferraz et al. (2008).

Essa situação dramática tende a se agravar ainda mais, considerando que o número de mortes no trânsito voltou a crescer a partir de 2001, após experimentar uma redução nos anos de 1998, 1999 e 2000 em decorrência da entrada em vigor do Código de Trânsito Brasileiro (Lei no 9.503 de 23/09/1997) em 28/01/1998.

Fontana (2005) cita que os seguintes fatos contribuem para um maior número de mortes no trânsito nos países não desenvolvidos ou em desenvolvimento: utilização intensa de veículos motorizados de duas rodas (motocicletas e assemelhados); veículos velhos; falta de manutenção dos veículos, das estradas e da sinalização de trânsito; falta de agentes, viaturas e equipamentos para fiscalização; atendimento médico precário dos acidentados; entre outros.

Os veículos mais utilizados nos países em desenvolvimento são os que estão mais expostos ao risco, conforme exemplificado na Figura 1.1. 


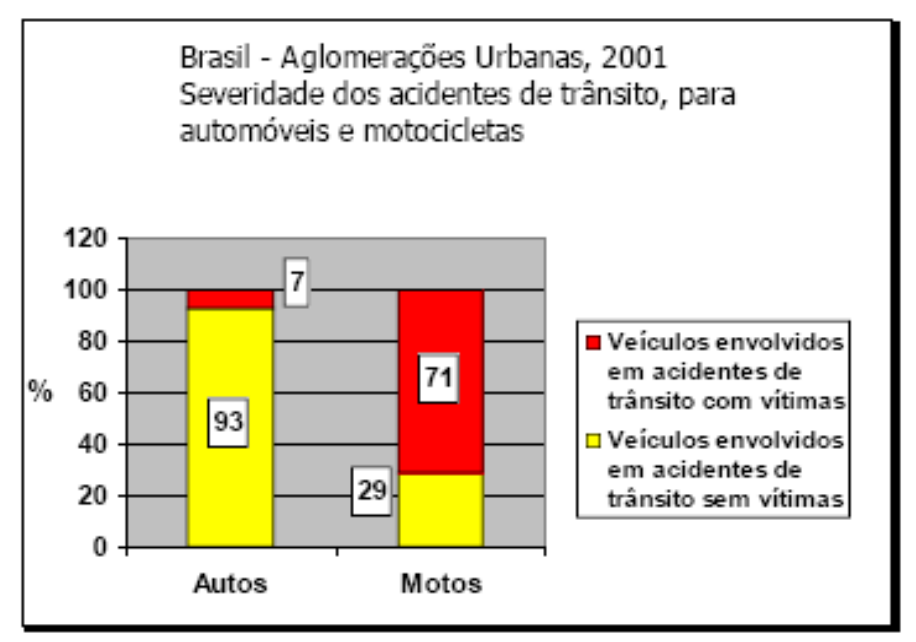

Figura 1.1: Severidade dos acidentes de trânsito. Fonte: IPEA (2003)

Dados do Ministério da Saúde indicam que os acidentes de trânsito no Brasil aumentaram $9 \%$ em três anos. No ano de 2002, 32.753 pessoas morreram em razão de acidentes; enquanto em 2005 os registros de óbito chegaram a 35.753. Outro dado da avaliação do Ministério da Saúde foi o aumento de $72 \%$ nos óbitos em municípios com menos de 100 mil habitantes, entre 1990 e 2005, quando passaram de 9.998 para 17.191.

\subsection{CUSTOS DOS ACIDENTES DE TRÂNSITO}

O custo dos acidentes de trânsito é um aspecto muito importante para ser tratado pelas autoridades governamentais, pois representa mundialmente 518 bilhões de dólares segundo a OMS (2004). Ainda de acordo com a OMS (2004), para o Brasil, país considerado com desenvolvimento médio, a estimativa anual de custo envolvendo os acidentes de trânsito é de 1,5\% do PIB, valor que ultrapassa a marca de 22 bilhões de reais para o ano de 2004, distribuídos da seguinte maneira: cerca de 6 bilhões de reais em acidentes ocorridos nas aglomerações urbanas e 16 bilhões de reais nas rodovias. Estes custos incluem: perda de produção, danos aos veículos, despesas médico-hospitalar, processos judiciais, congestionamentos, custo previdenciário, resgate das vítimas, remoção dos veículos, danos ao mobiliário 
urbano e à propriedade de terceiros, outro meio de transporte, danos à sinalização de trânsito e o impacto familiar.

Foram realizados no Brasil dois estudos recentes sobre os custos dos acidentes de trânsito: IPEA (2003) sobre acidentes nas cidades e IPEA (2006) sobre acidentes nas rodovias. Os valores médios dos custos por tipo de acidentes obtidos nesses estudos (atualizados para Junho de 2008, com base no IPCA do IBGE) estão indicados na Tabela 1.2.

Tabela 1.2 - Custos dos acidentes de trânsito no Brasil atualizados para Junho de 2008

\begin{tabular}{|c|c|c|c|}
\hline Discriminação & Rodovias & Cidades & Pais \\
\hline Acidente sem vítimas (R\$) & $18.733,00$ & $4.275,00$ & - \\
\hline Acidente com vítimas não fatais (R\$) & $95.705,00$ & $22.882,00$ & - \\
\hline Acidente com vítimas fatais (R\$) & $465.377,00$ & $188.902,00$ & - \\
\hline Todos os tipos de acidentes $^{\mathrm{a}}(\mathrm{R} \$)$ & $65.500,00$ & $11.509,00$ & - \\
\hline Total anual $^{\mathrm{b}}$ (bilhões de $\mathrm{R} \$$ /ano) & 24,47 & 6,95 & 31,42 \\
\hline
\end{tabular}

${ }^{\text {a }}$ Valores calculados considerando a distribuição percentual dos diversos tipos de acidentes ocorridos nas amostras analisadas nos estudos do IPEA (2003) e IPEA (2006).

${ }^{\mathrm{b}}$ Valor atualizado considerando que não houve variação do número de acidentes de cada tipo e total.

Fonte: Ferraz et al. (2008)

Segundo Ferraz et al. (2008), o valor do custo total para o país é de 31,42 bilhões de reais e corresponde a aproximadamente 1,23\% do PIB brasileiro previsto para 2008 (da ordem de 2,55 trilhões de reais). O valor de 1,23\% situa-se entre 1,0 e 1,5\% - que foram os valores adotados pela WHO (World Health Organization 2004) na estimativa do custo total dos acidentes nos países com baixo e médio desenvolvimento, respectivamente. 


\subsection{VISÃO SISTÊMICA DA SEGURANÇA VIÁRIA}

Uma visão sistêmica acerca da acidentalidade no trânsito representada em forma de quadro (matriz) foi desenvolvida pelo americano William Haddon, em 1980; uma versão adaptada dessa matriz é mostrada na Tabela 1.3. Nessa tabela estão relacionadas as principais ações associadas a cada um dos três elementos que compõem o sistema de trânsito no sentido de evitar os acidentes (período préacidente), de minimizar as consequiências dos acidentes no instante em que ocorrem (momento do acidente) e de minimizar os efeitos após os acidentes (período pósacidente).

O combate à acidentalidade viária envolve, basicamente, ações em três grandes áreas: Engenharia, Educação e Esforço Legal (Legislação e Fiscalização). Quando as ações envolvendo estas áreas são realizadas em conjunto e harmonia, os resultados na diminuição do número de acidentes são expressivos.

A Segurança Viária é um tema que abrange várias áreas do conhecimento, como Psicologia, Medicina, Mecânica, Eletrônica, Engenharia Civil, Urbanismo, entre outras. É, portanto, um tema multidisciplinar.

Dentro do grupo da Engenharia, podem-se citar as seguintes ações para reduzir a acidentalidade: alterações nos traçados das vias, melhoria na pavimentação, implantação de rotatórias, execução de passarelas, pontes e viadutos, bem como melhoria da sinalização viária. Dentre essas ações, a melhoria da sinalização é uma medida de baixo custo e com grande impacto na redução da acidentalidade.

Segundo FHWA (1989) apud FHWA (2003), a proporção investimentoretorno da sinalização viária é de 21:1. Ou seja, para cada 1 dólar investido em sinalização viária economiza-se 21 dólares com os acidentes de trânsito. 
Tabela 1.3 - Versão adaptada da matriz de Haddon

\begin{tabular}{|c|c|c|}
\hline PERÍODO & ELEMENTO & EXEMPLOS DE AÇÕES \\
\hline & Humano & $\begin{array}{l}\text { - Redução da exposição ao risco (diminuição da necessidade de viajar, } \\
\text { substituição de viagens por modos mais seguros, etc.); } \\
\text { • Conhecimento das normas e regras; } \\
\text { - Treinamento prático; } \\
\text { • Conscientização (convencimento) das pessoas visando comportamento } \\
\text { adequado; } \\
\text { - Legislação severa e fiscalização intensa; } \\
\text { - Uso de vestimenta com material refletivo por parte de pedestres, ciclistas, } \\
\text { motociclistas e trabalhadores das ruas no período noturno. }\end{array}$ \\
\hline & Veículo & $\begin{array}{l}\text { - Projeto voltado para proporcionar segurança; } \\
\text { - Manutenção adequada, em especial de freios, pneus, direção e suspensão; } \\
\text { - Vidros e/ou visor do capacete limpos e desembaçados; } \\
\text { - Material refletivo nas bicicletas e motocicletas para maior visibilidade noturna. }\end{array}$ \\
\hline & $\begin{array}{l}\text { Via/meio } \\
\text { ambiente }\end{array}$ & $\begin{array}{l}\text { - Geometria da via adequada; } \\
\text { - Limite de velocidade apropriado; } \\
\text { - Sinalização adequada; } \\
\text { - Rugosidade e drenagem da pista adequadas; } \\
\text { - Faixa lateral com superfície regular, pequena declividade e sem obstáculos; } \\
\text { - Inexistência de elementos próximos que prejudicam a visibilidade ou desviam } \\
\text { a atenção; } \\
\text { - Existência de painéis com mensagens variáveis para avisar sobre condições } \\
\text { climáticas adversas, existência de obras ou acidentes à frente, etc. }\end{array}$ \\
\hline \multirow{3}{*}{ 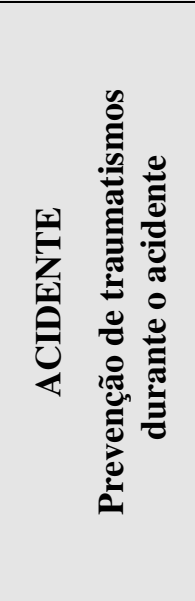 } & Humano & $\begin{array}{l}\text { - Velocidade compatível com o local; } \\
\text { - Uso de equipamentos de segurança (cinto de segurança, cadeiras especiais para } \\
\text { crianças, capacete para motociclistas, etc.); } \\
\text { - Crianças no banco traseiro; } \\
\text { - Cargas no porta-mala ou bagageiro. }\end{array}$ \\
\hline & Veículo & $\begin{array}{l}\text { - Estrutura externa resistente ao impacto para proteger os ocupantes; } \\
\text { - Parte frontal flexível para minimizar as lesões de pedestres, ciclistas e } \\
\text { motociclistas; } \\
\text { - Dotado de bolsa de ar (airbag). }\end{array}$ \\
\hline & $\begin{array}{l}\text { Via/meio } \\
\text { ambiente }\end{array}$ & $\begin{array}{l}\text { - Faixa lateral com superfície regular, baixa declividade e sem obstáculos; } \\
\text { - Barreiras de contenção nos locais críticos; } \\
\text { - Amortecedores de impacto em elementos rígidos próximos a pista. }\end{array}$ \\
\hline \multirow{3}{*}{ 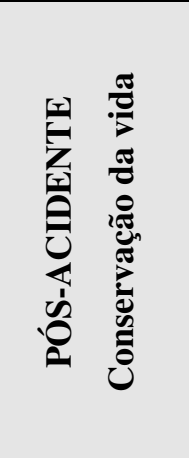 } & Humano & $\begin{array}{l}\text { - Rapidez na chegada ao local de atendimento especializado; } \\
\text { - Pessoal treinado e equipamentos adequados no socorro e transporte das } \\
\text { vítimas; } \\
\text { - Tratamento hospitalar de urgência e posterior adequados; } \\
\text { - Reabilitação física e psicológica das vítimas. }\end{array}$ \\
\hline & Veículo & $\begin{array}{l}\text { - Existência de extintor de incêndio; } \\
\text { - Retirada rápida da pista. }\end{array}$ \\
\hline & $\begin{array}{l}\mathrm{Via} / \mathrm{meio} \\
\text { ambiente }\end{array}$ & $\begin{array}{l}\text { - Sinalização de emergência da pista indicando o acidente; } \\
\text { - Limpeza da pista e recuperação dos dispositivos de controle (sinais de trânsito, } \\
\text { semáforos, etc.). }\end{array}$ \\
\hline
\end{tabular}

Fonte: Ferraz et al. (2008). 


\subsection{OBJETIVO DO TRABALHO}

Este trabalho tem como objetivo analisar a conspicuidade (capacidade de chamar a atenção dos condutores), a legibilidade (facilidade de leitura dos caracteres - letras e símbolos) e a retrorrefletividade (eficiência do material em refletir a luz incidente) de placas de sinalização viária, conforme o tipo de material empregado na confecção dos caracteres e do fundo da placa.

As análises da conspicuidade e da legibilidade foram realizadas em laboratório apropriado nas seguintes condições: em ambiente iluminado com luz forte (simulando as condições de trânsito nas rodovias e vias urbanas durante o período diurno), em ambiente totalmente escuro com a incidência de um feixe de luz direcionado diretamente sobre as placas simulando a luz dos farol dos veículos (simulando as condições do trânsito nas vias não iluminadas no período noturno) e em ambiente iluminado com luz fraca e com a incidência de um feixe de luz direcionado diretamente sobre as placas simulando a luz dos farol dos veículos (simulando as condições do trânsito nas vias iluminadas durante o período noturno).

Estas análises foram realizadas mediante entrevistas a motoristas utilizando o método da comparação aos pares da Psicofísica.

A avaliação da retrorrefletividade dos materiais empregados na confecção das placas também foi realizada no mesmo laboratório utilizando equipamento portátil de avaliação da retrorrefletividade. 


\subsection{ORGANIZAÇÃO DO TRABALHO}

O trabalho está dividido em sete capítulos. O primeiro apresenta um histórico e considerações sobre os acidentes de trânsito, a segurança viária, a sinalização de trânsito, o objetivo do trabalho e a sua organização.

O segundo capítulo trata sobre os tipos de sinalização que são regulamentados no Brasil: sinais impressos, gestos e sons.

No terceiro capítulo são discutidas as principais normas de sinalização, bem como estudos de diversos autores sobre o assunto.

O quarto capítulo relata o método da Psicofísica denominado de Comparação aos Pares, que é utilizado nos experimentos conduzidos neste trabalho.

No quinto capítulo são descritos os experimentos, o local onde foram realizados e os materiais utilizados.

O sexto capítulo apresenta os resultados obtidos nos experimentos.

No sétimo capítulo são apresentadas as conclusões e considerações relevantes no contexto do trabalho.

Em anexo são apresentados os formulários utilizados nos experimentos. 


\section{2 \\ SINALIZAÇÃO DE TRÂNSITO}

\subsection{CONSIDERAÇÕES INICIAIS}

A sinalização de trânsito tem por objetivo regulamentar as obrigações dos usuários do sistema viário (motoristas e pedestres), suas limitações e proibições ou restrições, advertir sobre situações de perigo e indicar o posicionamento dos veículos e direções a serem seguidas, para que os usuários possam chegar aos seus destinos de maneira ordenada e segura.

Segundo Ferraz et al. (1999), o objetivo da sinalização de trânsito é organizar a circulação de veículos e pessoas nas vias públicas através de informações relevantes para disciplina na movimentação de tráfego, proporcionando assim segurança, fluidez, conforto e comodidade aos usuários.

Segundo Fontana (2005), os sinais de trânsito constituem um dos mais importantes componentes da estrutura viária, sendo responsável pela comunicação aos usuários sobre como utilizar de maneira adequada às vias públicas. A sinalização é, assim, fundamental para a segurança e eficiência do trânsito.

De modo geral, a sinalização de trânsito compreende os seguintes elementos básicos: placas, marcas, luzes, gestos, sons, marcos, barreiras e dispositivos auxiliares.

Deve-se ter como princípio básico, na concepção e implantação da sinalização de trânsito, as condições de percepção dos usuários da via, garantindo assim a real eficácia dos sinais. Sendo assim, os sinais de trânsito devem possuir: 
- Legalidade: estar de acordo com o Código de Trânsito Brasileiro e a legislação complementar.

- Suficiência: fácil percepção do que realmente é importante, tendo somente a quantidade de sinalização necessária.

- Padronização: seguir um padrão estabelecido, sendo que situações iguais devem ser tratadas com os mesmos critérios.

- Clareza: mensagens objetivas de fácil compreensão.

- Precisão e Confiabilidade: corresponder a situação existente, ter credibilidade.

- Conspicuidade: conseguir chamar a atenção no ambiente em que está inserida.

- Visibilidade e Legibilidade: estar no campo de visão em posição adequada, e ser lida em tempo hábil para a tomada de decisão.

- Manutenção e Conservação: estar permanentemente limpa, conservada, fixa e livre de interferências para ser visível.

\subsection{TIPOS DE SINALIZAÇÃO DE TRÂNSITO}

A sinalização de trânsito possui três tipos principais de comunicação, são eles:

- Sinalização Vertical, através de placas fixadas em suportes.

- Sinalização Horizontal, através de marcações no pavimento.

- Sinalização Semafórica, através de conjuntos luminosos com cores distintas.

\subsubsection{Sinalização Vertical}

A sinalização vertical é um subsistema da sinalização viária, que se utiliza de sinais apostos sobre placas fixadas na posição vertical, ao lado ou suspensas sobre a pista, transmitindo mensagens de caráter permanente ou, eventualmente, variável, mediante símbolos e/ou legendas preestabelecidas e legalmente instituídas. 
A sinalização vertical tem a finalidade de fornecer informações que permitam aos usuários das vias adotarem comportamentos adequados, de modo a aumentar a segurança, ordenar os fluxos de tráfego e orientar os usuários da via.

A sinalização vertical é classificada segundo sua função, que pode ser de:

- regulamentar as obrigações, limitações, proibições ou restrições que governam o uso da via;

- advertir os condutores sobre condições com potencial risco existentes na via ou nas suas proximidades, tais como escolas e passagens de pedestres;

- indicar direções, localizações, pontos de interesse turístico ou de serviços e transmitir mensagens educativas, dentre outras, de maneira a ajudar o condutor em seu deslocamento.

Os sinais possuem formas padronizadas, associadas ao tipo de mensagem que pretendem transmitir, sejam elas de regulamentação, advertência ou indicação.

\section{- Sinalização de Regulamentação}

A sinalização vertical de regulamentação tem por finalidade transmitir aos usuários as condições, proibições, obrigações ou restrições no uso das vias urbanas e rurais. Os sinais de regulamentação em vigor no país são mostrados na Figura 2.1. $\mathrm{O}$ desrespeito aos sinais de regulamentação constitui infrações previstas no capítulo XV do Código de Trânsito Brasileiro.

Nas Tabelas 2.1, 2.2 e 2.3 estão indicadas as dimensões mínimas e recomendadas dos sinais de regulamentação.

A maioria dos sinais de regulamentação tem validade no ponto em que esta implantada ou a partir deste ponto, podendo também ter validade na face de quadras, vinculados à sinalização horizontal ou informações complementares. 
A forma padrão do sinal de regulamentação é circular, tendo suas cores vermelha (orla), preta (legenda) e branca (fundo), como indicado na Figura 2.2; suas únicas exceções de forma são os sinais R-1 - "Parada Obrigatória" e R-2 - "Dê a preferência".

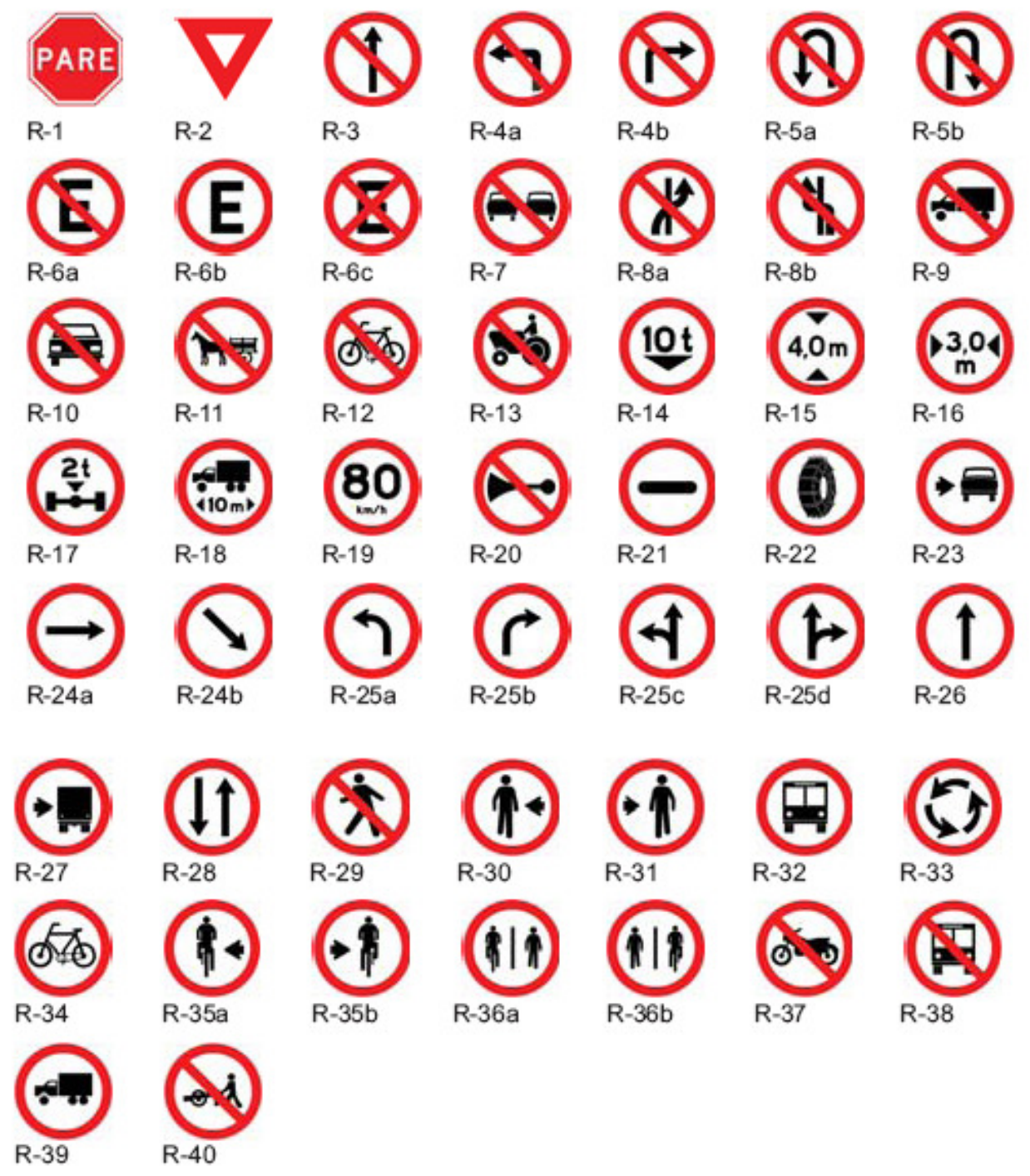

Figura 2.1 - Conjunto dos sinais de regulamentação. Fonte: Anexo II do Código de Trânsito Brasileiro. 
Características dos Sinais de Regulamentaçăo

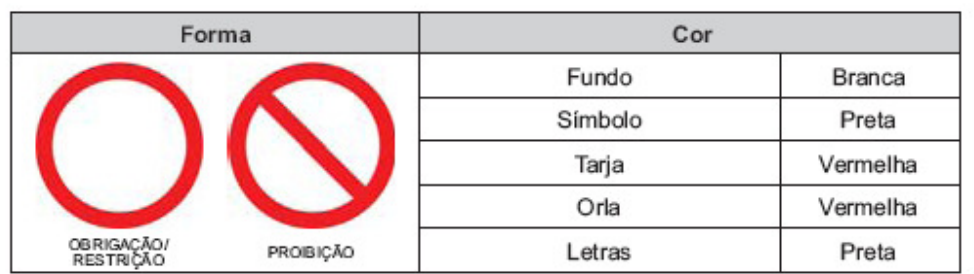

Caracteristicas dos Sinais R-1 e R-2

\begin{tabular}{|c|c|c|c|}
\hline \multicolumn{2}{|c|}{ Sinal } & \multirow{2}{*}{\multicolumn{2}{|c|}{ Cor }} \\
\hline \multirow[t]{7}{*}{ Forma } & Código & & \\
\hline & \multirow{4}{*}{$\mathrm{R}-1$} & Fundo & Vermelha \\
\hline & & Orla interna & Branca \\
\hline & & Orla externa & Vermelha \\
\hline & & Letras & Branca \\
\hline & \multirow[b]{2}{*}{ R-2 } & Fundo & Branca \\
\hline & & Orla & Vermelha \\
\hline & & & \\
\hline
\end{tabular}

Figura 2.2 - Características dos Sinais de Regulamentação. Fonte: Anexo II do Código de Trânsito Brasileiro.

Tabela 2.1 - Dimensões mínimas e recomendadas para sinais circulares

\begin{tabular}{|c|c|c|c|c|c|c|}
\hline Via & \multicolumn{2}{|c|}{ Diâmetro (m) } & \multicolumn{2}{|c|}{ Tarja $(\mathbf{m})$} & \multicolumn{2}{|c|}{ Orla (m) } \\
\hline & mínimo & recomendado & mínimo & recomendado & mínimo & recomendado \\
\hline $\begin{array}{l}\text { Urbana } \\
\text { (transito rápido) }\end{array}$ & \multirow{2}{*}{0,40} & 0,75 & \multirow{2}{*}{0,04} & 0,075 & \multirow{2}{*}{0,04} & 0,075 \\
\hline $\begin{array}{c}\text { Urbana } \\
\text { (demais vias) }\end{array}$ & & 0,50 & & 0,05 & & 0,05 \\
\hline $\begin{array}{l}\text { Rural } \\
\text { (estrada) }\end{array}$ & 0,50 & 0,75 & 0,05 & 0,075 & 0,05 & 0,075 \\
\hline $\begin{array}{c}\text { Rural } \\
\text { (rodovia) }\end{array}$ & 0,75 & 1,00 & 0,075 & 0,10 & 0,075 & 0,10 \\
\hline $\begin{array}{c}\text { Áreas } \\
\text { protegidas por } \\
\text { legislação } \\
\text { especial }(*) \\
\end{array}$ & 0,30 & - & 0,03 & - & 0,03 & - \\
\hline
\end{tabular}

(*) relativa a patrimônio histórico, artístico, cultural arquitetônico, arqueológico e natural.

Fonte: Anexo II do Código de Trânsito Brasileiro. 
Tabela 2.2 - Dimensões mínimas e recomendadas - sinal de forma octógona - R-1

\begin{tabular}{|c|c|c|c|c|c|c|}
\hline Via & \multicolumn{2}{|c|}{ Lado Mínimo (m) } & \multicolumn{2}{c|}{$\begin{array}{c}\text { Orla interna branca } \\
\text { mínima (m) }\end{array}$} & \multicolumn{2}{c|}{$\begin{array}{c}\text { Orla externa vermelha } \\
\text { mínima (m) }\end{array}$} \\
\hline & mínimo & recomendado & mínimo & recomendado & mínimo & recomendado \\
\hline Urbana & 0,25 & 0,35 & 0,020 & 0,028 & 0,010 & 0,014 \\
\hline $\begin{array}{c}\text { Rural } \\
\text { (estrada) }\end{array}$ & 0,35 & 0,35 & 0,028 & 0,028 & 0,014 & 0,014 \\
\hline $\begin{array}{c}\text { Rural } \\
\text { (rodovia) }\end{array}$ & 0,40 & 0,50 & 0,032 & 0,040 & 0,016 & 0,020 \\
\hline $\begin{array}{c}\text { Áreas } \\
\text { protegidas por } \\
\text { legislação } \\
\text { especial (*) }\end{array}$ & 0,18 & - & 0,015 & - & 0,008 & - \\
\hline
\end{tabular}

(*) relativa a patrimônio histórico, artístico, cultural arquitetônico, arqueológico e natural.

Fonte: Anexo II do Código de Trânsito Brasileiro.

Tabela 2.3 - Dimensões mínimas e recomendadas - sinal de forma triangular - R-2

\begin{tabular}{|c|c|c|c|c|}
\hline Via & \multicolumn{2}{|c|}{ Lado (m) } & \multicolumn{2}{c|}{ Tarja (m) } \\
\hline & mínimo & recomendado & mínimo & recomendado \\
\hline Urbana & 0,75 & 0,90 & 0,10 & 0,15 \\
\hline $\begin{array}{c}\text { Rural } \\
\text { (estrada) }\end{array}$ & 0,75 & 0,90 & 0,10 & 0,15 \\
\hline $\begin{array}{c}\text { Rural } \\
\text { (rodovia) }\end{array}$ & 0,90 & 1,00 & 0,15 & 0,20 \\
\hline $\begin{array}{c}\text { Areas } \\
\text { protegidas por } \\
\text { legislação } \\
\text { especial (*) }\end{array}$ & 0,40 & - & 0,06 & - \\
\\
Fol) relativa a patrimônio histórico, artístico, cultural arquitetônico, arqueológico e natural. \\
Fonte: Anexo II do Código de Trânsito Brasileiro.
\end{tabular}

Os sinais de regulamentação podem ser aplicados em placas pintadas, retrorrefletivas, luminosas (iluminação interna) ou iluminadas (iluminação externa frontal).

Segundo o CONTRAN: "Recomenda-se que sejam, pelo menos, retrorrefletivas as placas: R-1 "Parada Obrigatória", R-2 "Dê a preferência" e R-19 "Velocidade Máxima”. Nas rodovias ou vias de trânsito rápido, não dotadas de iluminação pública, as placas devem ser pelo menos retrorrefletivas". 
As informações básicas para execução de uma sinalização, relativas a materiais e posicionamento, independentemente da mensagem que ela transmita são as seguintes:

- Placas

- chapa: aço, alumínio, plástico reforçado ou madeira imunizada.

- pintura: esmalte sintético, fosco ou semi-fosco ou pintura eletrostática (o verso da placa deverá ser de cor preta fosca ou semi-fosca).

- película não refletiva

- película refletiva: esferas inclusas, esferas encapsuladas ou prismáticas

- Suporte

- material: aço ou madeira imunizada

- cores: neutras

- formas: que não interfiram na interpretação do significado do sinal

As placas de sinalização devem ser mantidas na posição apropriada, sempre limpas e legíveis. Para que isto ocorra é necessária a adequada manutenção e conservação das placas de sinalização.

O posicionamento de uma placa de sinalização é de extrema importância para que esta possa ser vista, lida e compreendida, de maneira rápida, pelo usuário do sistema. Seguem, nas Figuras 2.3 a 2.6, algumas regras básicas de posicionamento da sinalização:

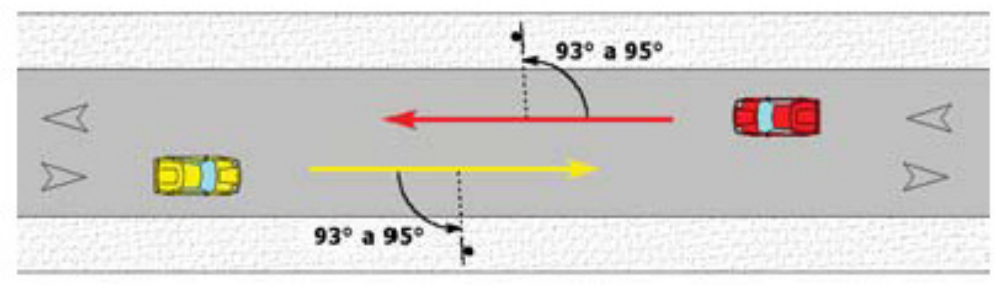

Figura 2.3 - Posicionamento em relação ao sentido de fluxo de tráfego. Fonte: Manual Brasileiro de Sinalização de Trânsito, Volume I, Conselho Nacional de Trânsito. 

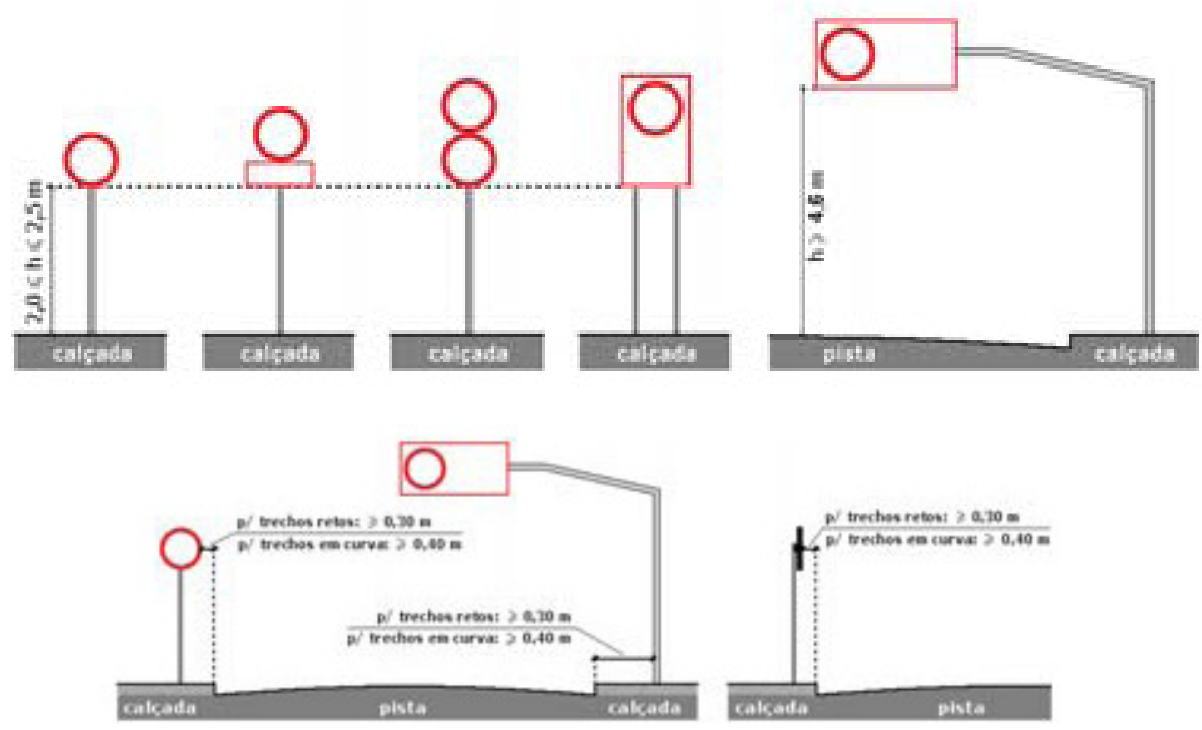

Figura 2.4 - Posicionamento básico de placas em vias urbanas. Fonte: Manual Brasileiro de Sinalização de Trânsito, Volume I, Conselho Nacional de Trânsito.
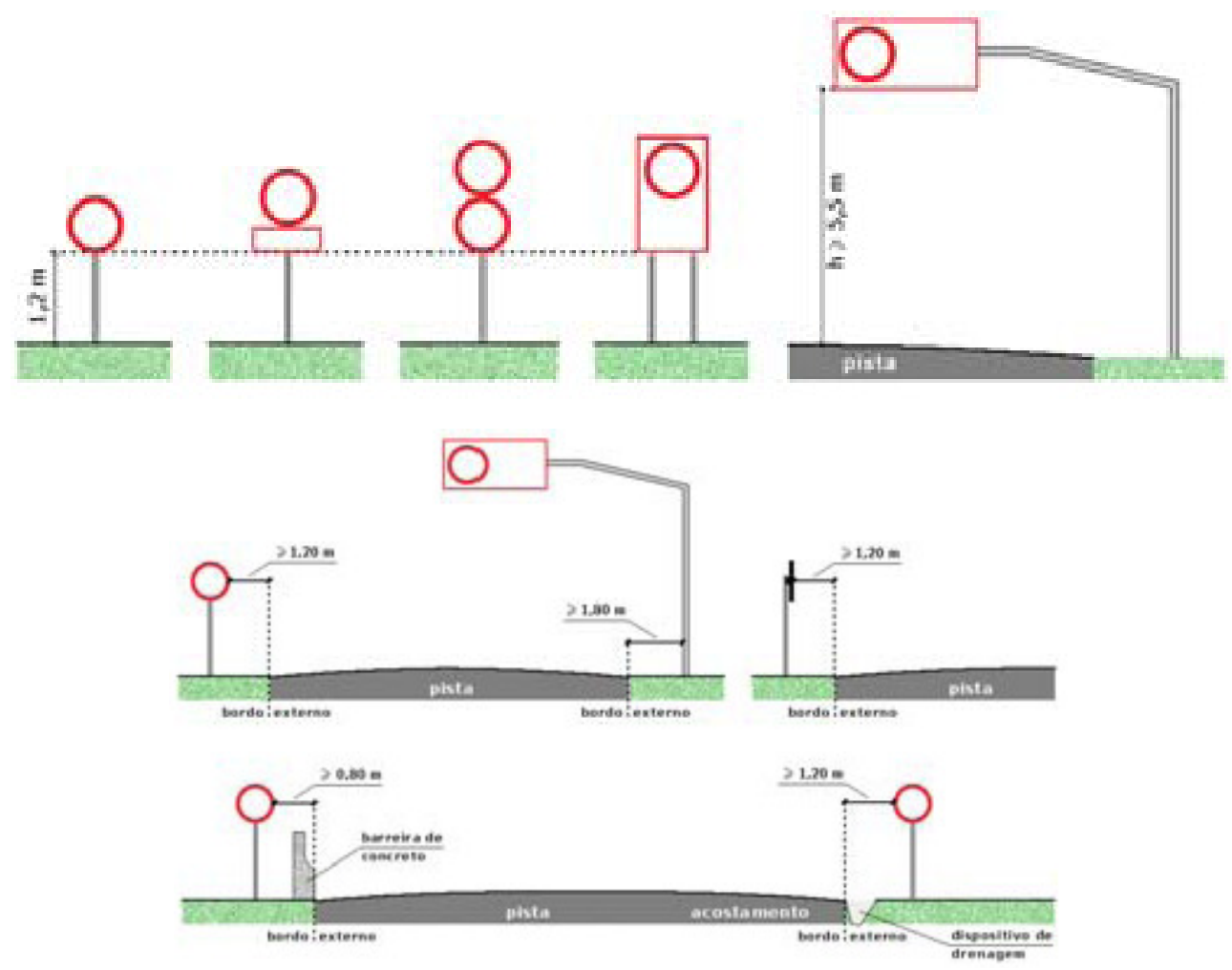

Figura 2.5 - Posicionamento básico de placas em vias rurais. Fonte: Manual Brasileiro de Sinalização de Trânsito, Volume I, Conselho Nacional de Trânsito. 


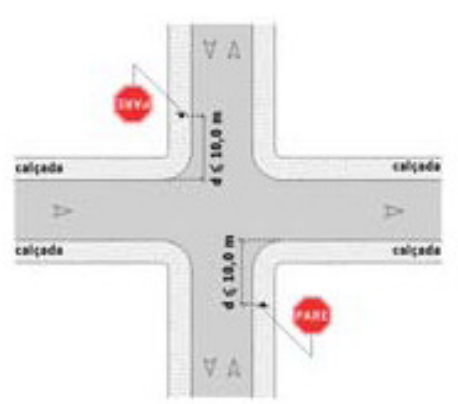

Fig. 9 via urbana

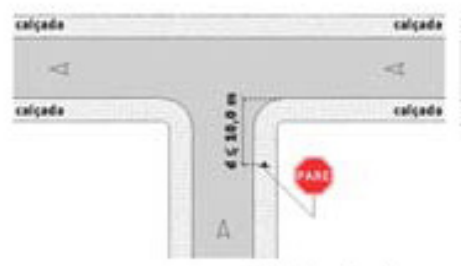

Fig. 11 via urbana

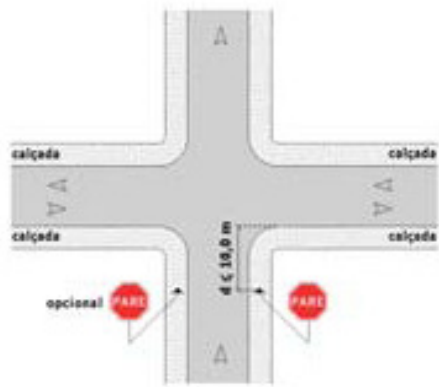

Fig. 10 via urbana

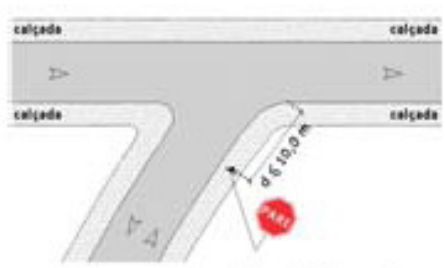

Fig. 12 via urbana

Figura 2.6 - Exemplo de localização do sinal de regulamentação R-1. Fonte: Manual Brasileiro de Sinalização de Trânsito, Volume I, Conselho Nacional de Trânsito.

\section{- Sinalização de Advertência}

A sinalização vertical de advertência tem por finalidade alertar aos usuários as condições potencialmente perigosas, obstáculos ou restrições existentes na via ou adjacentes a ela, indicando a natureza dessas situações a frente, quer sejam permanentes ou eventuais. Os sinais de advertência em vigor no país são mostrados na Figura 2.7.

Deve ser utilizada sempre que o perigo não se evidencie por si só, e exigindo, geralmente, uma redução de velocidade, com o objetivo de propiciar maior segurança ao trânsito.

A forma padrão dos sinais de advertência é a quadrada, devendo uma das diagonais ficar na posição vertical, e as cores são amarela e preta. São exceções, 
quanto à forma, os sinais: A-26 a "Sentido único", A-26 b "Sentido Duplo" e A-41

"Cruz de Santo André"; quanto a cor: A-14 "Semáforo a frente" e A-24 "Obras".

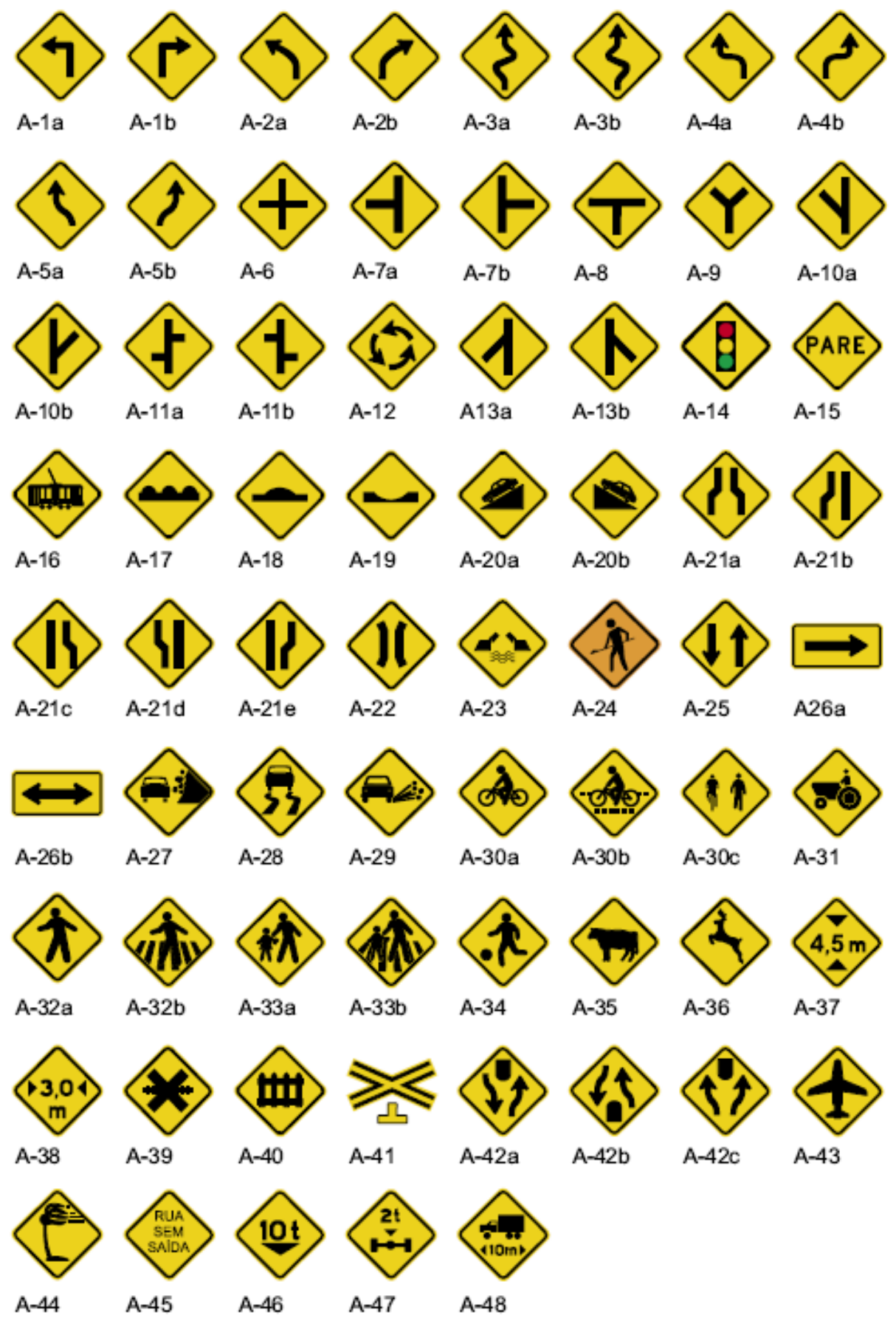

Figura 2.7 - Conjunto de Sinais de Advertência. Fonte: Anexo II do Código de Trânsito Brasileiro. 
Na Figura 2.8 estão indicadas as principais características dos sinais de advertência.

\section{Características dos Sinais de advertência}

\begin{tabular}{|c|c|c|}
\hline \multirow{2}{*}{ Forma } & \multicolumn{2}{|c|}{ Cor } \\
\hline \multirow{2}{*}{} & Fundo & Amarela \\
\cline { 2 - 3 } & Simbolo & Preta \\
\cline { 2 - 3 } & Orla intema & Preta \\
\cline { 2 - 3 } & Oria extema & Pmarela \\
\cline { 2 - 3 } & Legenda & Preta \\
\hline
\end{tabular}

\section{Características do Sinal A-14}

\begin{tabular}{|c|c|c|}
\hline Forma & \multicolumn{2}{|c|}{ Cor } \\
\hline & Fundo & Amarela \\
\hline & Simbolo & $\begin{array}{c}\text { Verde } \\
\text { Amarela } \\
\text { Vermelha } \\
\text { Preta }\end{array}$ \\
\hline & Orla intema & Preta \\
\hline & Orla extema & Amarela \\
\hline
\end{tabular}

\section{Características do Sinal A-24}

\begin{tabular}{|c|c|c|}
\hline \multirow{2}{*}{ Forma } & \multicolumn{2}{|c|}{ Cor } \\
\hline \multirow{2}{*}{} & Fundo & Laranja \\
\cline { 2 - 3 } & Simbolo & Preta \\
\cline { 2 - 3 } & Orla intema & Preta \\
\cline { 2 - 3 } & Orla externa & Laranja \\
\hline
\end{tabular}

Características dos Sinais A-26 a - A-26 b - A-41

\begin{tabular}{|c|c|c|c|}
\hline \multicolumn{2}{|c|}{ Sinal } & \multirow{2}{*}{\multicolumn{2}{|c|}{ Cor }} \\
\hline \multirow[t]{7}{*}{ Forma } & Código & & \\
\hline & \multirow{4}{*}{$\begin{array}{l}\text { A-26a } \\
\text { A-26b }\end{array}$} & Fundo & Amarela \\
\hline & & Orla intema & Preta \\
\hline & & Orla extema & Amarela \\
\hline & & Simbolo & Preta \\
\hline & \multirow{2}{*}{$A-41$} & Fundo & Amarela \\
\hline & & $\begin{array}{l}\text { Orla intema } \\
\text { Orla extema }\end{array}$ & $\begin{array}{l}\text { Preta } \\
\text { Amarela }\end{array}$ \\
\hline
\end{tabular}

Figura 2.8 - Características dos sinais de advertência. Fonte: Anexo II do Código de Trânsito Brasileiro. 
Nas Tabelas 2.4 a 2.6 estão indicadas as dimensões mínimas dos sinais de advertência.

Tabela 2.4 - Dimensões mínimas - sinais de forma quadrada

\begin{tabular}{|c|c|c|c|}
\hline Via & $\begin{array}{c}\text { Lado mínimo } \\
\text { (m) }\end{array}$ & $\begin{array}{l}\text { Orla externa } \\
\text { mínima (m) }\end{array}$ & $\begin{array}{c}\text { Orla interna } \\
\text { mínima(m) }\end{array}$ \\
\hline Urbana & 0,45 & 0,009 & 0,018 \\
\hline $\begin{array}{l}\text { Rural } \\
\text { (estrada) }\end{array}$ & 0,50 & 0,010 & 0,020 \\
\hline $\begin{array}{l}\text { Rural } \\
\text { (rodovia) }\end{array}$ & 0,60 & 0,012 & 0,024 \\
\hline $\begin{array}{c}\text { Áreas } \\
\text { protegidas por } \\
\text { legislação } \\
\text { especial }(*)\end{array}$ & 0,30 & 0,006 & 0,012 \\
\hline
\end{tabular}

Tabela 2.5 - Dimensões mínimas - sinais de forma retangular

\begin{tabular}{|c|c|c|c|c|}
\hline Via & $\begin{array}{c}\text { Lado maior } \\
\text { mínimo (m) }\end{array}$ & $\begin{array}{c}\text { Lado menor } \\
\text { mínimo }(\mathbf{m})\end{array}$ & $\begin{array}{c}\text { Orla externa } \\
\text { mínima (m) }\end{array}$ & $\begin{array}{c}\text { Orla interna } \\
\text { Mínima(m) }\end{array}$ \\
\hline Urbana & 0,50 & 0,25 & 0,005 & 0,010 \\
\hline $\begin{array}{c}\text { Rural } \\
\text { (estrada) }\end{array}$ & 0,80 & 0,40 & 0,008 & 0,016 \\
\hline $\begin{array}{c}\text { Rural } \\
\text { (rodovia) }\end{array}$ & 1,00 & 0,50 & 0,010 & 0,020 \\
\hline $\begin{array}{c}\text { Areas } \\
\text { protegidas por } \\
\text { legislação } \\
\text { especial (*) }\end{array}$ & 0,40 & 0,20 & 0,006 & 0,012 \\
\hline \multicolumn{3}{|l|}{ (*) relativa a patrimônio histórico, artístico, cultural arquitetônico, arqueológico e natural. } \\
Fonte: Anexo II do Código de Trânsito Brasileiro.
\end{tabular}

Tabela 2.6 - Dimensões mínimas - Cruz de Santo André - A-41

\begin{tabular}{|c|c|}
\hline Parâmetro & Variação \\
\hline $\begin{array}{c}\text { Relação entre dimensões de largura e } \\
\text { comprimento dos braços }\end{array}$ & de 1:6 a 1:10 \\
\hline Ângulos menores formados entre os dois braços & Entre $45^{\circ}$ e $55^{\circ}$ \\
\hline
\end{tabular}

Fonte: Anexo II do Código de Trânsito Brasileiro. 
Os sinais de advertência podem ser aplicados em placas pintadas, retrorrefletivas, luminosas (iluminação interna) ou iluminadas (iluminação externa frontal).

Segundo o CONTRAN: "Nas rodovias ou vias de trânsito rápido, não dotadas de iluminação pública, as placas devem ser pelo menos retrorrefletivas”.

Como o sinal de advertência precede um acontecimento, existem alguns fatores que devem ser analisados, no tocante à localização das placas, como: distância de visibilidade e distância de desaceleração e/ou manobra. A Figura 2.9 ilustra o fato.

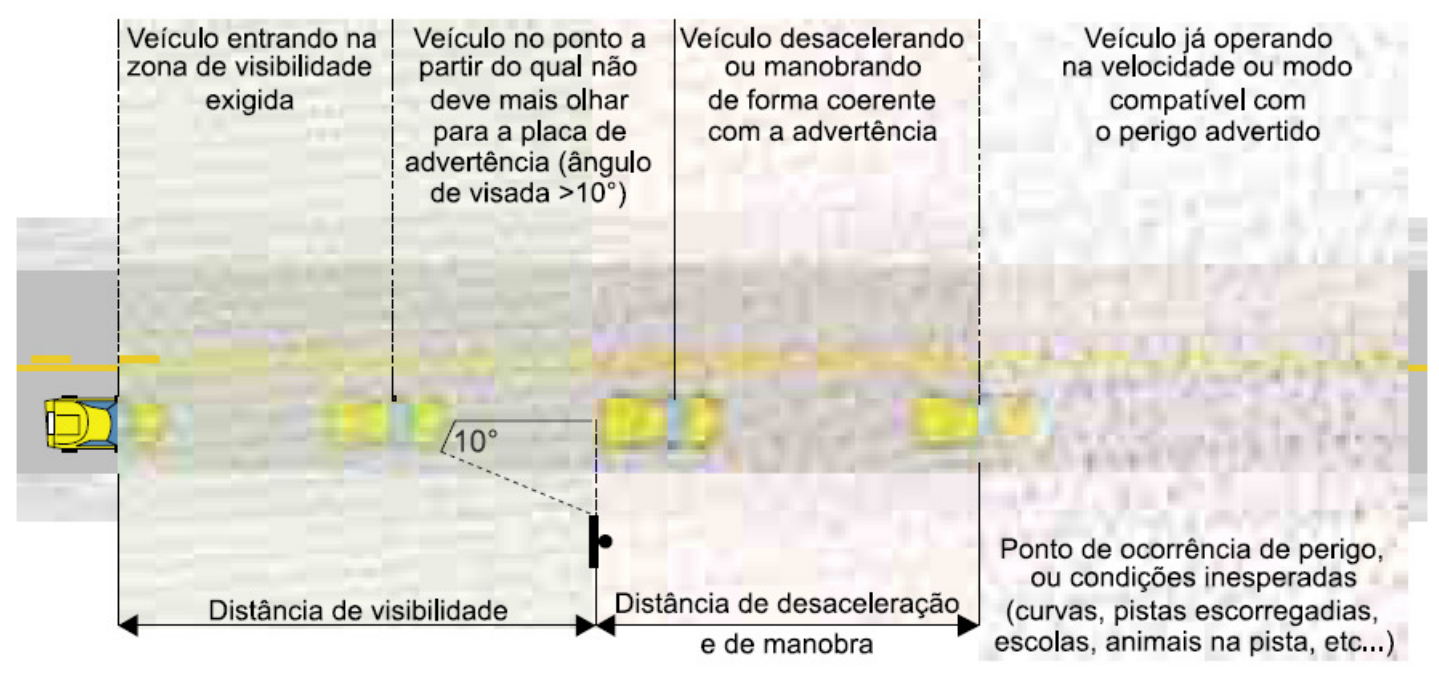

Figura 2.9 - Visualização de uma placa em tempo real. Fonte: Manual Brasileiro de Sinalização de Trânsito, Volume II, Conselho Nacional de Trânsito.

Os fatores básicos para análise da distância de visibilidade são os seguintes: tempo de percepção e reação de 2,5 segundos e que quando o veículo (alinhado na via) formar um ângulo maior que $10^{\circ}$ em relação à placa o condutor deixa de visualizá-la. Para a análise da distância de desaceleração e/ou manobra adota-se uma desaceleração suave e constante de $2,00 \mathrm{~m} / \mathrm{s}^{2}$. 
$\mathrm{Na}$ Tabela 2.7 estão indicadas as distâncias mínimas de visibilidade associadas às diversas velocidades do veículo e, na Tabela 2.8, as distâncias mínimas de desaceleração e/ou manobra.

Tabela 2.7 - Distância mínima de visibilidade

\begin{tabular}{|c|c|}
\hline Velocidade de aproximação $(\mathrm{Km} / \mathrm{h})$ & Distância mínima de visibilidade $(\mathrm{m})$ \\
\hline 40 & 60 \\
\hline 50 & 70 \\
\hline 60 & 80 \\
\hline 70 & 85 \\
\hline 80 & 95 \\
\hline 90 & 105 \\
\hline 100 & 115 \\
\hline 110 & 125 \\
\hline 120 & 135 \\
\hline
\end{tabular}

Fonte: Manual Brasileiro de Sinalização de Trânsito, Volume II, Conselho Nacional de Trânsito.

Tabela 2.8 - Distância mínima de desaceleração e/ou manobra

\begin{tabular}{|c|c|c|}
\hline Tho de vias & $\begin{array}{c}\text { Velocidade -V } \\
(\mathrm{km} / \mathrm{h})\end{array}$ & $\begin{array}{l}\text { Distância mínima de } \\
\text { desaceleração elou } \\
\text { manobra }(\mathrm{m})\end{array}$ \\
\hline \multirow{3}{*}{ Urbanas } & $V<60$ & 50 \\
\hline & $60 \leq V<80$ & 100 \\
\hline & $V \geq 80$ & 150 \\
\hline \multirow{3}{*}{ Rurais } & $V<60$ & 100 \\
\hline & $60 \leq V \leq 80$ & 150 \\
\hline & $V>80$ & 200 \\
\hline
\end{tabular}

Fonte: Manual Brasileiro de Sinalização de Trânsito, Volume II, Conselho Nacional de Trânsito.

Nas Figuras de 2.10 a 2.12 são mostrados exemplos de localização dos sinais de advertência. 


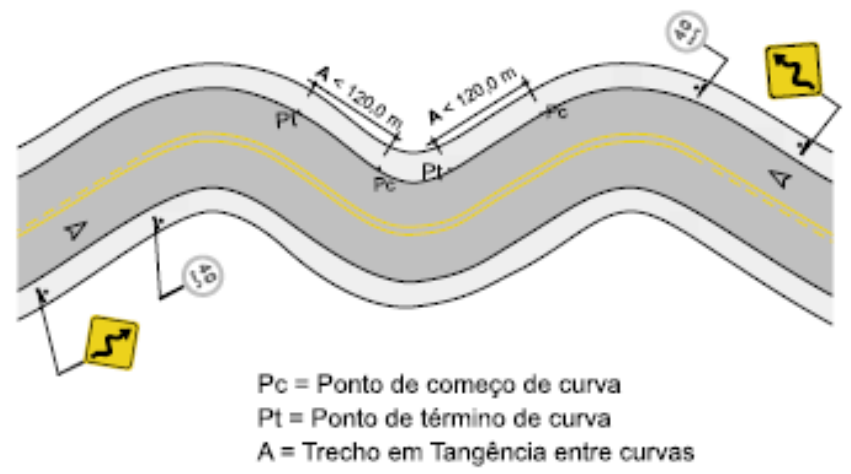

Figura 2.10 - Exemplo de localização do sinal de advertência A-3 a e A-3 b "Pista sinuosa a esquerda" e "Pista sinuosa a direita". Fonte: Manual Brasileiro de Sinalização de Trânsito, Volume II, Conselho Nacional de Trânsito.

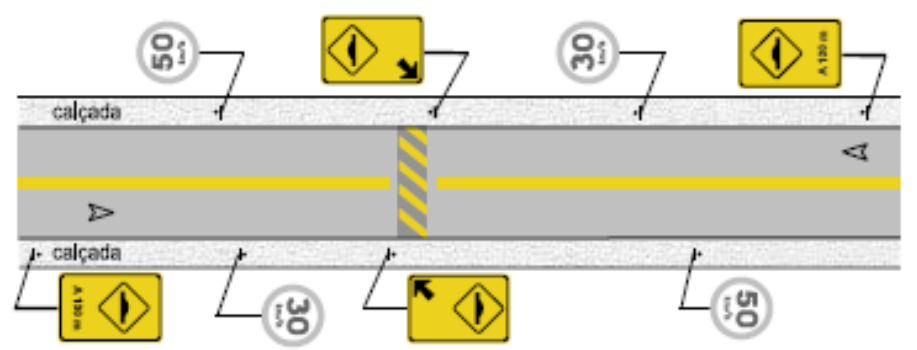

Figura 2.11 - Exemplo de localização do sinal de advertência A-18 "Lombada". Fonte: Manual Brasileiro de Sinalização de Trânsito, Volume II, Conselho Nacional de Trânsito.

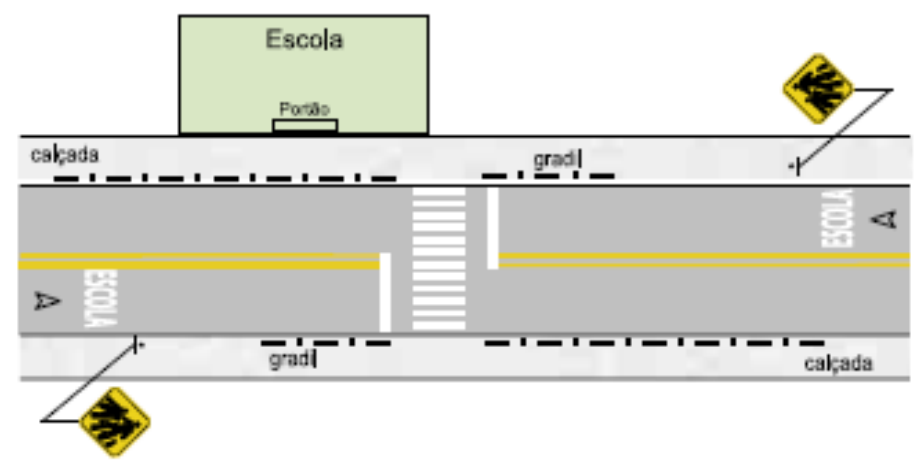

Figura 2.12 - Exemplo de localização do sinal de advertência A-33 b "Passagem sinalizada de escolares". Fonte: Manual Brasileiro de Sinalização de Trânsito, Volume II, Conselho Nacional de Trânsito. 


\section{- Sinalização de Indicação}

A sinalização de indicação tem por finalidade identificar as vias e os locais de interesse, bem como orientar condutores de veículos quanto aos percursos, os destinos, as distâncias e os serviços auxiliares, podendo também ter como função a educação do usuário. Portanto, suas mensagens possuem caráter informativo e educativo.

As placas de indicação estão divididas nos seguintes grupos:

- Placas de Identificação, como exemplificado nas Figuras de 2.13 a 2.19.
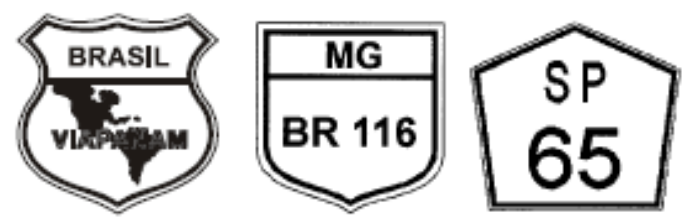

Figura 2.13 - Sinalização de Identificação de rodovias e estradas. Fonte: Anexo II do Código de Trânsito Brasileiro.

\section{Piracicaba}

Figura 2.14 - Identificação de municípios. Fonte: Ilustração feita pelo autor.

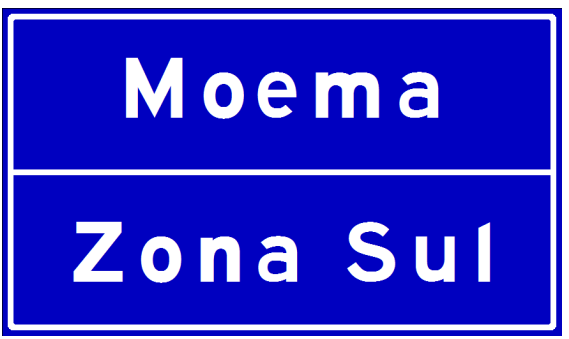

Figura 2.15 - Identificação de regiões de interesse de tráfego e logradouros. Fonte: Ilustração feita pelo autor. 


\section{Ponte Cidade Jardim \\ Zona Sul}

Figura 2.16 - Identificação nominal de pontes, viadutos, túneis e passarelas. Fonte: Ilustração feita pelo autor.

\begin{tabular}{|c|}
\hline Norte \\
\hline $\mathrm{km}$ \\
153 \\
\hline
\end{tabular}

Figura 2.17 - Identificação quilométrica. Fonte: Ilustração feita pelo autor.

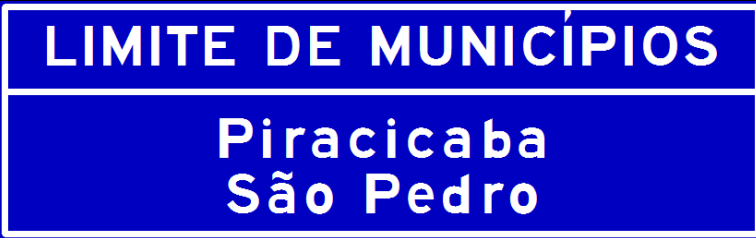

Figura 2.18 - Identificação de limite de município. Fonte: Ilustração feita pelo autor.

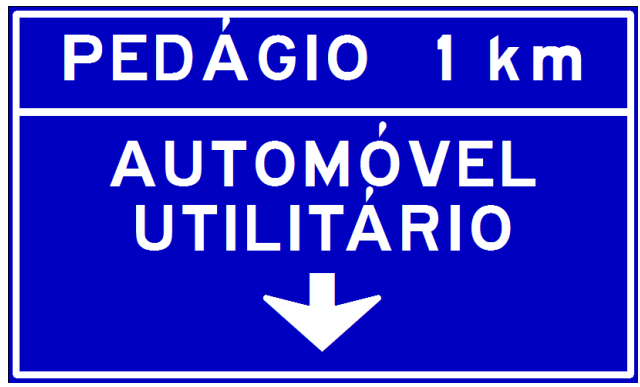

Figura 2.19 - Placa de pedágio. Fonte: Ilustração feita pelo autor.

- Placas de Orientação de Destino, como exemplificado nas Figuras 2.20 a 2.22.

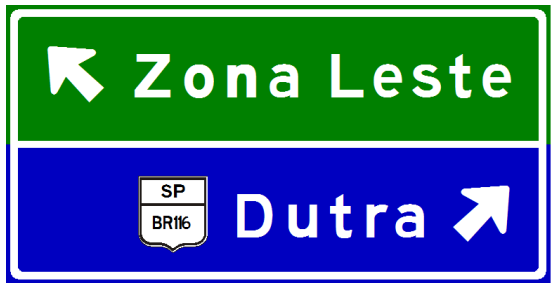

Figura 2.20 - Placas indicativas de sentido. Fonte: Ilustração feita pelo autor. 


\section{Piracicaba $12 \mathrm{~km}$ São Pedro $42 \mathrm{~km}$}

Figura 2.21 - Placas indicativas de distância. Fonte: Ilustração feita pelo autor.

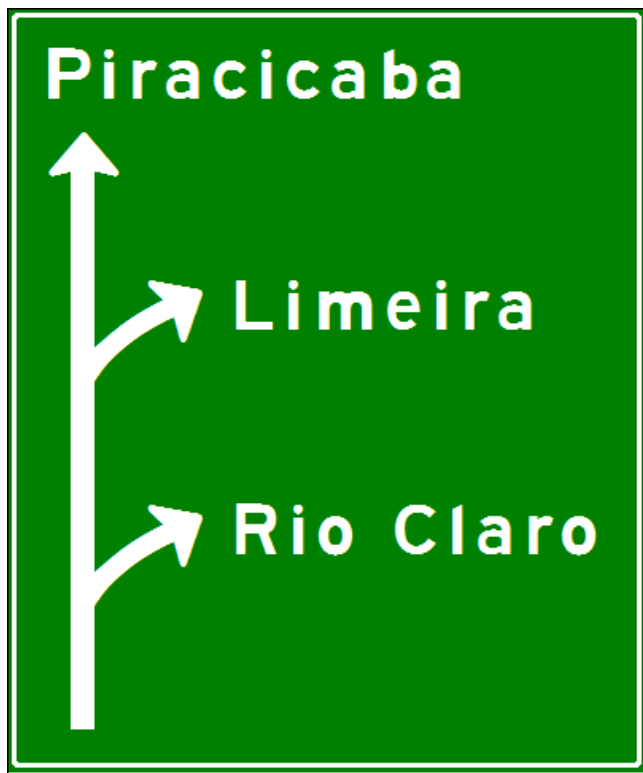

Figura 2.22 - Placas diagramadas. Fonte: Ilustração feita pelo autor.

- Placas Educativas, como exemplificado na Figura 2.23.

\section{MOTORISTA RESPEITE A SINALIZAÇÃO}

Figura 2.23 - Placas Educativas. Fonte: Ilustração feita pelo autor.

- Placas de Serviços Auxiliares, como exemplificado nas Figuras 2.24 e 2.25.

\section{Hospital S. Carlos $\rightarrow$}

Figura 2.24 - Placas serviços auxiliares (condutores). Fonte: Ilustração feita pelo autor. 


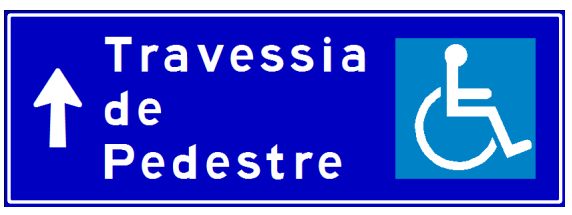

Figura 2.25 - Placas serviços auxiliares (pedestres). Fonte: Ilustração feita pelo autor.

- Placas de Atrativos Turísticos, como exemplificado nas Figuras 2.26 a 2.28.

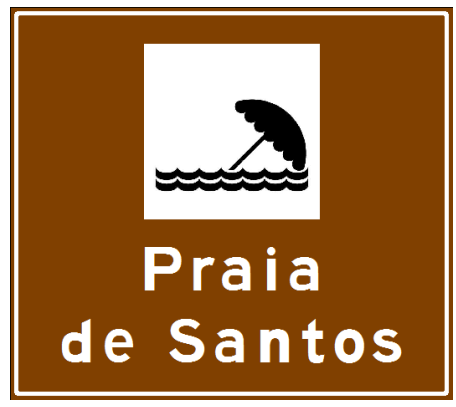

Figura 2.26 - Placa de atrativo turístico. Fonte: Ilustração feita pelo autor.

$$
\begin{aligned}
& \text { — Î́ Igr. Embaré } \\
& \text { 个 IIII Mus. Pescador }
\end{aligned}
$$

Figura 2.27 - Placa de sentido de atrativo turístico. Fonte: Ilustração feita pelo autor.

$$
\triangle \text { Santos } 26 \mathrm{~km}
$$

Figura 2.28 - Placa de distância de atrativo turístico. Fonte: Ilustração feita pelo autor. 


\subsubsection{Sinalização Horizontal}

A sinalização horizontal é um subsistema da sinalização viária composta de marcas, símbolos e legendas, apostos sobre o pavimento da pista de rolamento. Tem a finalidade de fornecer informações que permitam aos usuários das vias adotarem comportamentos adequados, de modo a aumentar a segurança e fluidez do trânsito, ordenar o fluxo de tráfego, canalizar e orientar os usuários da via.

As funções da Sinalização Horizontal são:

- Ordenar e canalizar o fluxo de veículos;

- Orientar o fluxo de pedestres;

- Orientar os descolamentos de veículos em função das condições físicas das vias, tais como, geometria, topografia e obstáculos;

- Complementar os sinais verticais de regulamentação, advertência ou indicação, com o objetivo de enfatizar a mensagem transmitida pelo sinal;

- Regulamentar os casos previstos no Código de Trânsito Brasileiro.

Existem situações que a sinalização horizontal atua por si só, como controladora de fluxos, podendo vir a ser complementada com dispositivos auxiliares.

A grande vantagem da sinalização horizontal é de estar no centro do campo visual do motorista, não precisando este desviar a atenção para ver e interpretar a mensagem. Outra vantagem da sinalização horizontal, em comparação com a sinalização vertical, é de ela receber uma quantidade muito maior (cerca de 1000 vezes mais) de luz dos faróis dos veículos, tornando-a mais visível e legível no período noturno. As desvantagens são a menor durabilidade, principalmente quando submetida a tráfego intenso, e a falta de visibilidade quando existe neblina, pavimento molhado ou tráfego intenso. 
A sinalização horizontal é composta por combinações de traçado e cores que definem os diversos tipos de marcas viárias. Possuindo as seguintes características básicas:

a) Traçado:

- contínuo: linhas sem interrupção.

- tracejado: linhas interrompidas, aplicadas em cadência.

- setas, símbolos e legendas: informações por meio de desenho ou inscritas.

b) Cores:

- amarela: separar movimentos de fluxos opostos, proibições e demarcações de obstáculos;

- branca: separar movimentos de mesmo sentido, regulamentações, delimitações e inscrever setas símbolos e legendas;

- vermelha: demarcar ciclovias ou ciclofaixas e inscrever símbolo (cruz);

- azul: inscrever símbolo em áreas especiais para pessoas com deficiência física;

- preta: utilizada como contraste em pavimentos claros.

As larguras das linhas, bem como o seu correto dimensionamento são definidas em função das características físicas e operacionais da via, do tipo de linha e/ou da velocidade regulamentada para a via.

Existem diversos tipos de materiais para execução da sinalização horizontal (tintas, termoplásticos, bi componentes, películas, entre outros), porém a escolha correta destes elementos deve seguir a seguinte análise: característica do projeto (provisório ou permanente), volume de tráfego (VDM) e sua distribuição, qualidade e vida útil do pavimento, freqüência de manutenção, dentre outros.

De acordo com o Manual Brasileiro de Sinalização de Trânsito, Volume IV, do Conselho Nacional de Trânsito, tendo como objetivo uma melhor visibilidade noturna a sinalização horizontal deve ser sempre retrorrefletiva. 
Nas Figuras de 2.29 a 2.32 seguem exemplos de sinalização horizontal.

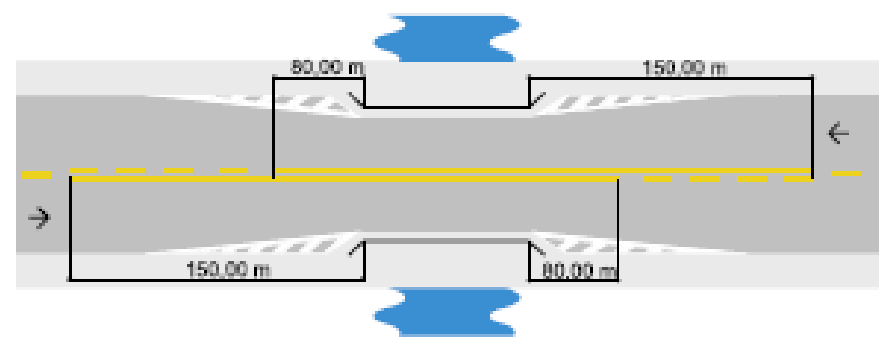

Figura 2.29 - Aproximação de Obras de Arte. Fonte: Manual Brasileiro de Sinalização de Trânsito, Volume IV, Conselho Nacional de Trânsito.

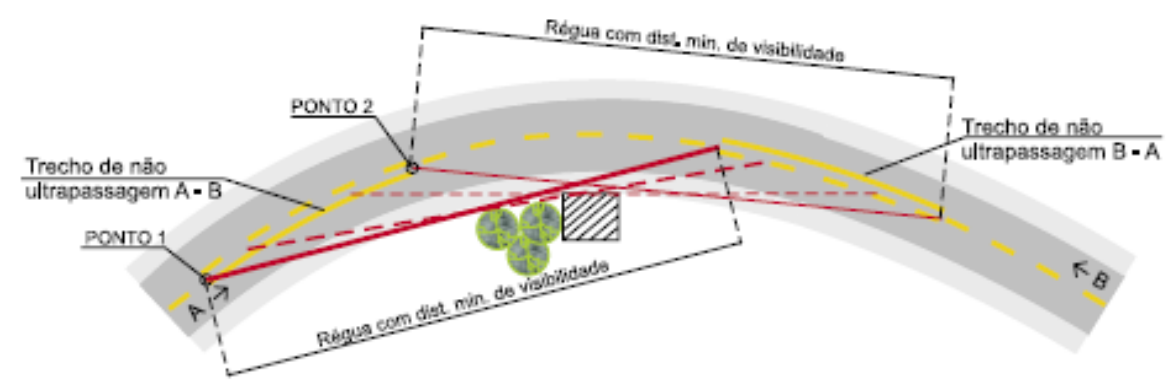

Figura 2.30 - Distância de Visibilidade de Ultrapassagem. Fonte: Manual Brasileiro de Sinalização de Trânsito, Volume IV, Conselho Nacional de Trânsito.

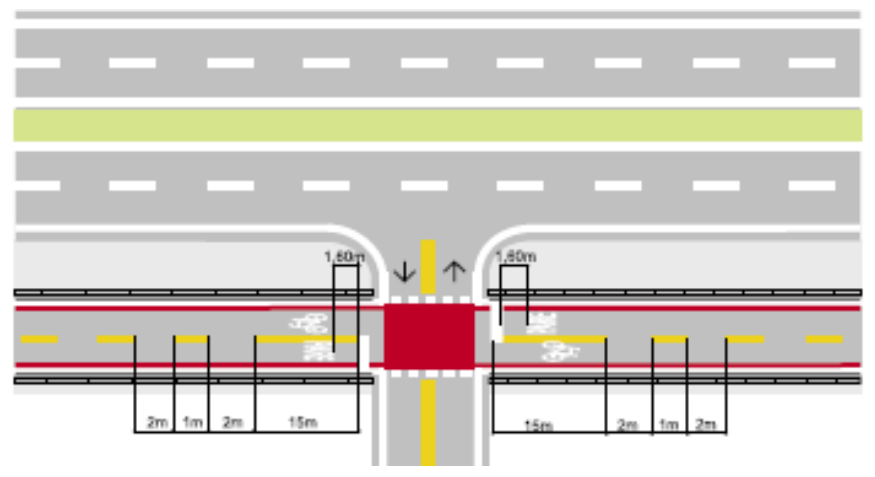

Figura 2.31 - Exemplo de ciclo-faixa. Fonte: Manual Brasileiro de Sinalização de Trânsito, Volume IV, Conselho Nacional de Trânsito. 


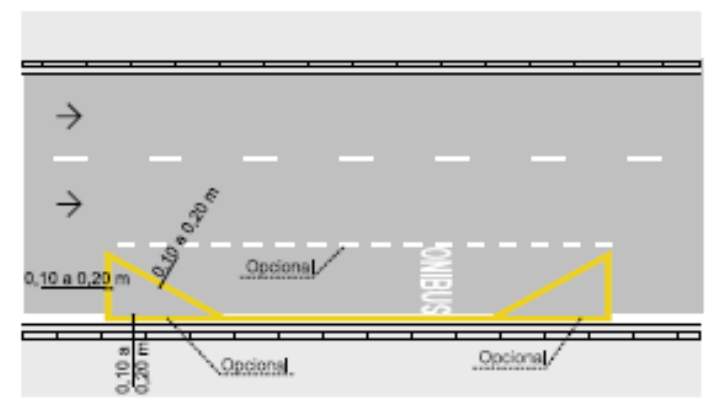

Figura 2.32 - Exemplo de Parada de Veículos Específicos. Fonte: Manual Brasileiro de Sinalização de Trânsito, Volume IV, Conselho Nacional de Trânsito.

\subsubsection{Dispositivos Auxiliares}

Os dispositivos de sinalização auxiliar são elementos de materiais, forma cor e refletividade diversos, utilizados na via, junto a ela ou em obstáculos próximos, de forma a tornar mais segura e eficiente a operação da via. Tem a função de:

- aumentar a percepção da sinalização, do alinhamento ou de obstáculos;

- reduzir a velocidade;

- oferecer proteção aos usuários;

- alertar os condutores quanto a situações de perigo ou que requeiram atenção.

De acordo com suas funções, os dispositivos de sinalização auxiliar, são classificados nos seguintes grupos:

- dispositivo delimitador, como exemplos os balizadores e tachas;

- dispositivo de canalização, como exemplo os prismas de plástico ou concreto;

- dispositivo de sinalização de alerta, como exemplo as placas de marcador de obstáculo;

- alterações nas características do pavimento, como exemplo fresagem do pavimento;

- dispositivos de proteção contínua, como exemplo a defensa metálica;

- dispositivos luminosos, como exemplos os painéis eletrônicos;

- dispositivos de uso temporário, como exemplos os cones e cavaletes plásticos ou de madeira. 
Na Figura 2.33 são mostrados exemplos de dispositivos auxiliares de sinalização viária.
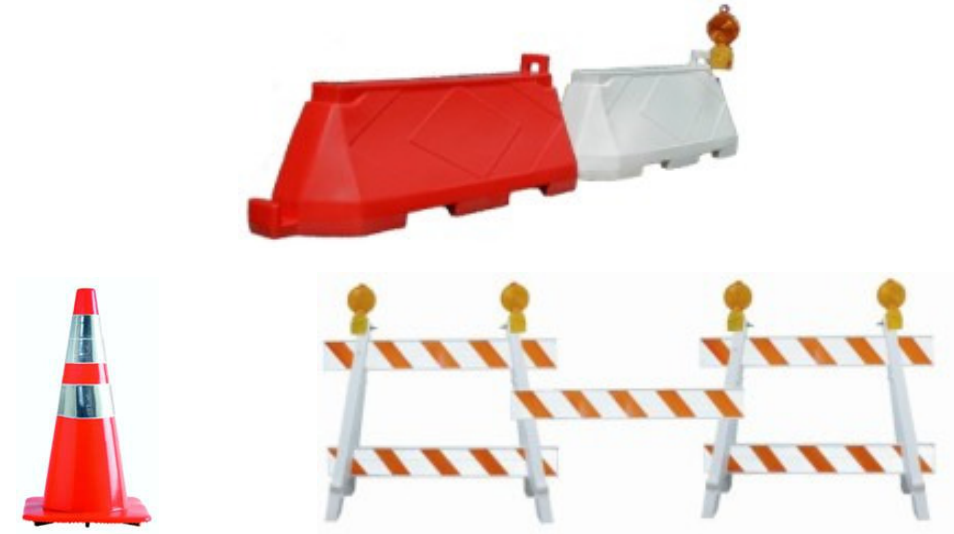

Figura 2.33 - Exemplos de Dispositivos Auxiliares. Fonte: Ilustração feita pelo autor.

\subsubsection{Sinalização Semafórica}

A sinalização semafórica é um subsistema da sinalização viária que se compõe de indicações luminosas acionadas alternada ou intermitentemente através de sistema elétrico / eletrônico, cuja função é controlar deslocamentos. Sendo classificada em dois grupos, como segue:

- Sinalização semafórica de regulamentação: efetuando o controle do trânsito num cruzamento ou seção de via, através de indicações luminosas, alternando o direito de passagem. As cores utilizadas são: vermelho (obrigatório parar), amarelo (atenção) e verde (passagem permitida). Dispostas verticalmente ou horizontalmente, sempre na seqüência: vermelho, amarelo, verde (de cima para baixo, quando verticalmente, ou da esquerda para a direita, quando horizontalmente), como exemplificado na Figura 2.34 .
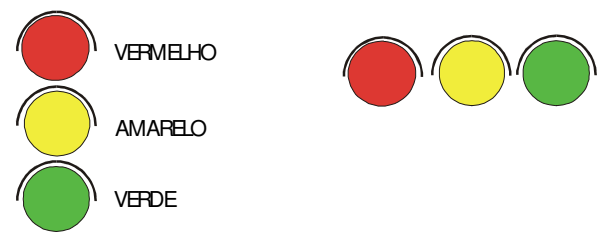

Figura 2.34 - Exemplo Semáforo de Regulamentação. Fonte: Anexo II do Código de Trânsito Brasileiro. 
- Sinalização semafórica de advertência: é composta por uma ou duas luzes de cor amarela, cujo funcionamento é intermitente ou piscante alternado, no caso de duas indicações luminosas, como exemplificado na Figura 2.35.
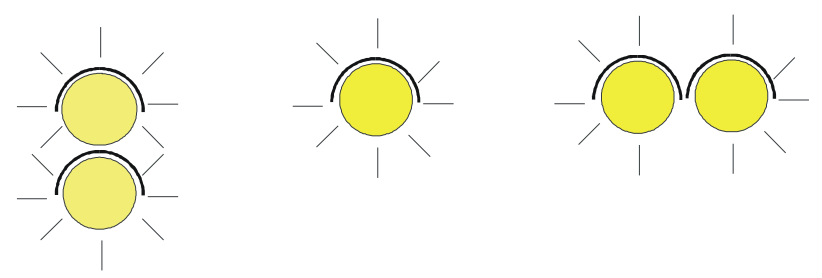

Figura 2.35 - Exemplo de Semáforo de Advertência. Fonte: Anexo II do Código de Trânsito Brasileiro.

\subsubsection{Sinalização de Obras}

A sinalização de obras tem como característica a utilização dos sinais e elementos de sinalização vertical, horizontal e dispositivos de sinalização auxiliar combinados de forma a advertir os usuários sobre a intervenção realizada, preservando as condições de segurança e fluidez e orientando sobre caminhos alternativos. As placas de advertência e orientação recebem as cores laranja e preto; os demais tipos de sinalização mantêm suas características. Na Figura 2.36 são mostrados exemplos de placas que advertem sobre a existência de obras.
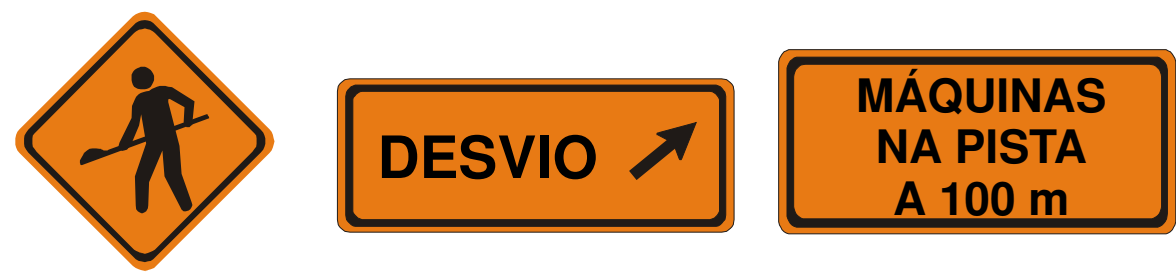

Figura 2.36 - Exemplo de placas de Sinalização de Obras. Fonte: Anexo II do Código de Trânsito Brasileiro. 


\subsubsection{Gestos}

As ordens emanadas por gestos de Agentes da Autoridade de Trânsito prevalecem sobre as regras de circulação e as normas definidas por outros sinais de trânsito.

Os gestos utilizados estão indicados nas Tabelas 2.9 e 2.10 .

Tabela 2.9 - Gestos dos Condutores

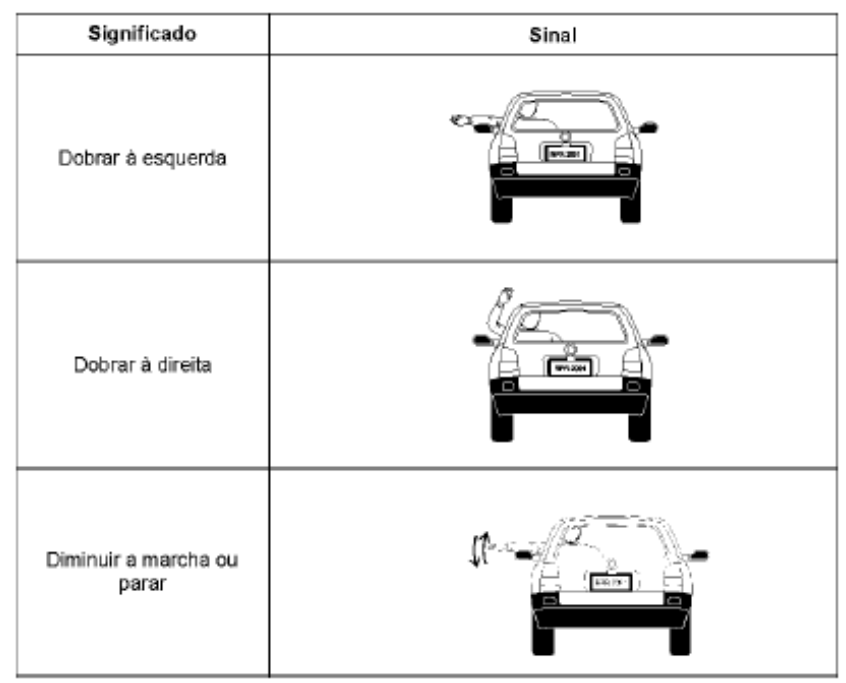

Fonte: Anexo II do Código de Trânsito Brasileiro. 
Tabela 2.10 - Gestos das Autoridades de Trânsito

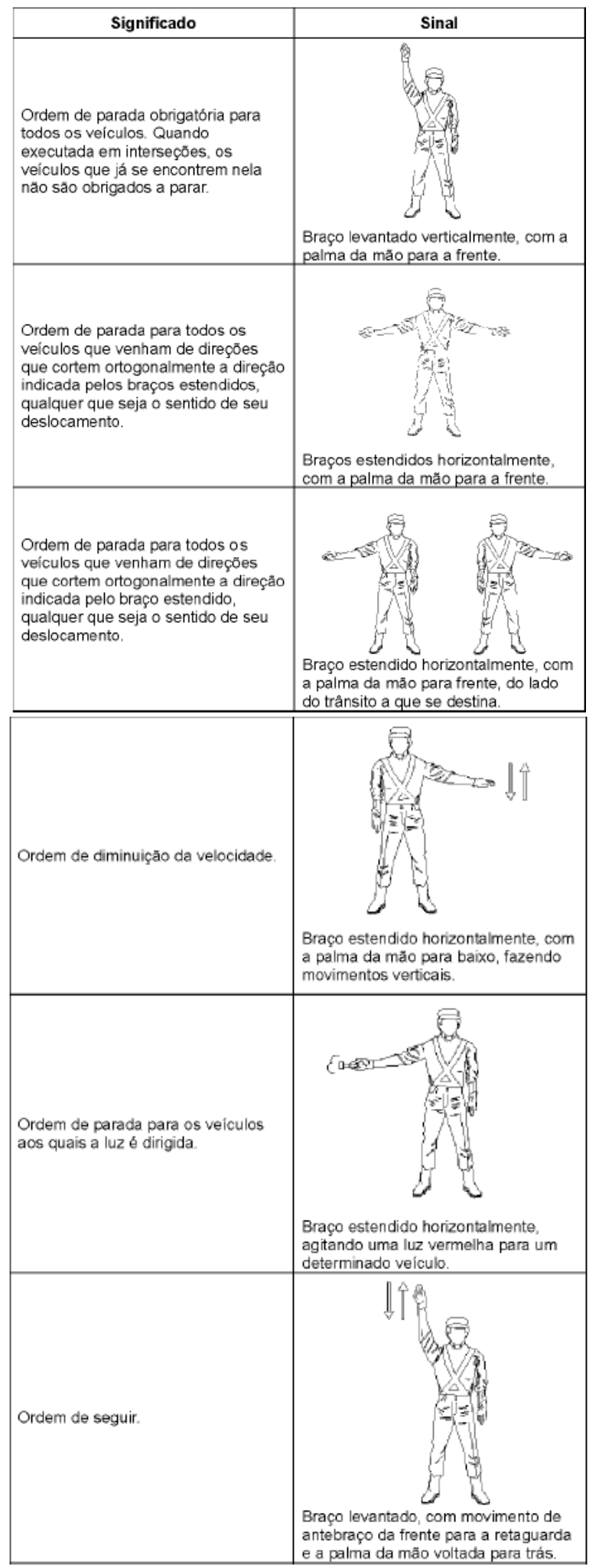

Fonte: Anexo II do Código de Trânsito Brasileiro. 


\subsubsection{Sinais Sonoros}

Os sinais sonoros somente devem ser utilizados em conjunto com os gestos dos agentes, como indicado na Tabela 2.11.

Tabela 2.11 - Sinais sonoros

\begin{tabular}{|c|c|c|}
\hline Sinais de apito & Significado & Emprego \\
\hline um silvo breve & siga & $\begin{array}{c}\text { liberar o trânsito em direção } \\
\text { / sentido indicado pelo } \\
\text { agente. }\end{array}$ \\
\hline dois silvos breves & pare & indicar parada obrigatória \\
\hline um silvo longo & diminuir a marcha & $\begin{array}{c}\text { quando for necessário fazer } \\
\text { diminuir a marcha dos } \\
\text { veículos. }\end{array}$ \\
\hline
\end{tabular}

Fonte: Anexo II do Código de Trânsito Brasileiro. 


\section{ESTUDOS E NORMAS RELEVANTES SOBRE SINALIZAÇÃO VIÁRIA}

$\mathrm{Na}$ Tabela 3.1 estão relacionadas às principais variáveis que afetam a conspicuidade e a legibilidade dos sinais verticais de trânsito.

Tabela 3.1 - Variáveis relacionadas à conspicuidade e legibilidade dos sinais verticais de trânsito

\begin{tabular}{|c|c|c|c|}
\hline SINAL TRÂNSITO & VEÍCULO & MOTORISTA & $\begin{array}{c}\text { CONDIÇÕES } \\
\text { CLIMÁTICAS/RODOVIA } \\
\end{array}$ \\
\hline 1. Posicionamento & 1. Tipo & $\begin{array}{l}\text { 1. Características } \\
\text { Visuais }\end{array}$ & $\begin{array}{l}\text { 1. Condições } \\
\text { Atmosféricas }\end{array}$ \\
\hline 1.1 Sinais Baixos & 1.1 Carro esporte & 1.1 Acuidade visual & 1.1 Chuva \\
\hline 1.1.1 Direita & 1.2 Carro de passeio & $\begin{array}{l}\text { 1.2 Sensibilidade ao } \\
\text { contraste }\end{array}$ & 1.2 Neblina \\
\hline 1.1.2 Esquerda & $\begin{array}{l}\text { 1.3 Caminhonete ou } \\
\text { Utilitário Esportivo }\end{array}$ & $\begin{array}{l}\text { 1.3 Deficiência em } \\
\text { identificar cores }\end{array}$ & 1.3 Ventos \\
\hline 1.2 Sinais Suspensos & 1.4 Caminhões grandes & 1.4 Outras & 1.4 Outros \\
\hline 1.2.1 Esquerda da faixa & 2. Lâmpada & 2. Medo & $\begin{array}{l}\text { 2. Complexibilidade do } \\
\text { ambiente }\end{array}$ \\
\hline 1.2.2 Centro da faixa & 2.1 Tipo & 3. Problemas Mentais & 2.1 Urbano \\
\hline 1.2.3 Direita da faixa & $\begin{array}{l}\text { 2.1.1 Halogênia - } \\
\text { Tungstênio }\end{array}$ & 4. Álcool e Drogas & 2.1.1 Residencial \\
\hline 2. Tamanho & $\begin{array}{l}\text { 2.1.2 Alta Intensidade de } \\
\text { descarga }\end{array}$ & & 2.1.2 Escola \\
\hline 3. Substrato & $\begin{array}{l}\text { 2.2 Distribuição da } \\
\text { Iluminação }\end{array}$ & & 2.1.3 Comercial \\
\hline 4. Cor & 2.3 Direção & & 2.1.4 Industrial \\
\hline 4.1 Legenda & 2.4 Claridade & & 2.2 Rural \\
\hline 4.2 Fundo & 3. Pára-brisa & & 3. Período do dia \\
\hline 5. Legenda & $\begin{array}{l}\text { 3.1 Transmissibilidade de } \\
\text { luz }\end{array}$ & & 3.1 Dia \\
\hline 5.1 Símbolo & 3.2 Limpeza & & 3.2 Noite \\
\hline 5.2 Alfabeto & 4. Voltagem constante & & 3.3 Amanhecer/Anoitecer \\
\hline 5.2.1 Fonte & & & $\begin{array}{l}\text { 4. Alinhamento } \\
\text { Horizontal }\end{array}$ \\
\hline 5.2.2 Tamanho letra & & & 5. Alinhamento Vertical \\
\hline 5.2.3 Espessura letra & & & $\begin{array}{l}\text { 6. Distância de } \\
\text { Segurança }\end{array}$ \\
\hline $\begin{array}{l}\text { 5.2.4 Espaçamento entre } \\
\text { letras }\end{array}$ & & & $\begin{array}{l}\text { 7. Refletância do } \\
\text { Pavimento }\end{array}$ \\
\hline $\begin{array}{l}\text { 5.2.5 Espaçamento entre } \\
\text { linhas }\end{array}$ & & & \\
\hline 6. Luminosidade & & & \\
\hline $\begin{array}{l}\text { 7. Retrorefletividade do } \\
\text { material }\end{array}$ & & & \\
\hline
\end{tabular}

Fonte: Carlson e Hawkings (2003) 
No período noturno, são quatro os principais fatores que impactam a visibilidade e a legibilidade dos sinais verticais: a intensidade de luz que sai do farol do veículo (expressa em candela), a quantidade de luz que chega ao sinal iluminância (expressa em lux), a eficiência do material retrorrefletivo retrorrefletividade (expressa em candela/lux $/ \mathrm{m}^{2}$ ) e o retorno de luz que faz o sinal parecer brilhante ao motorista - luminância (expressa em candela $/ \mathrm{m}^{2}$ ). A Figura 3.1 ilustra os conceitos mencionados.

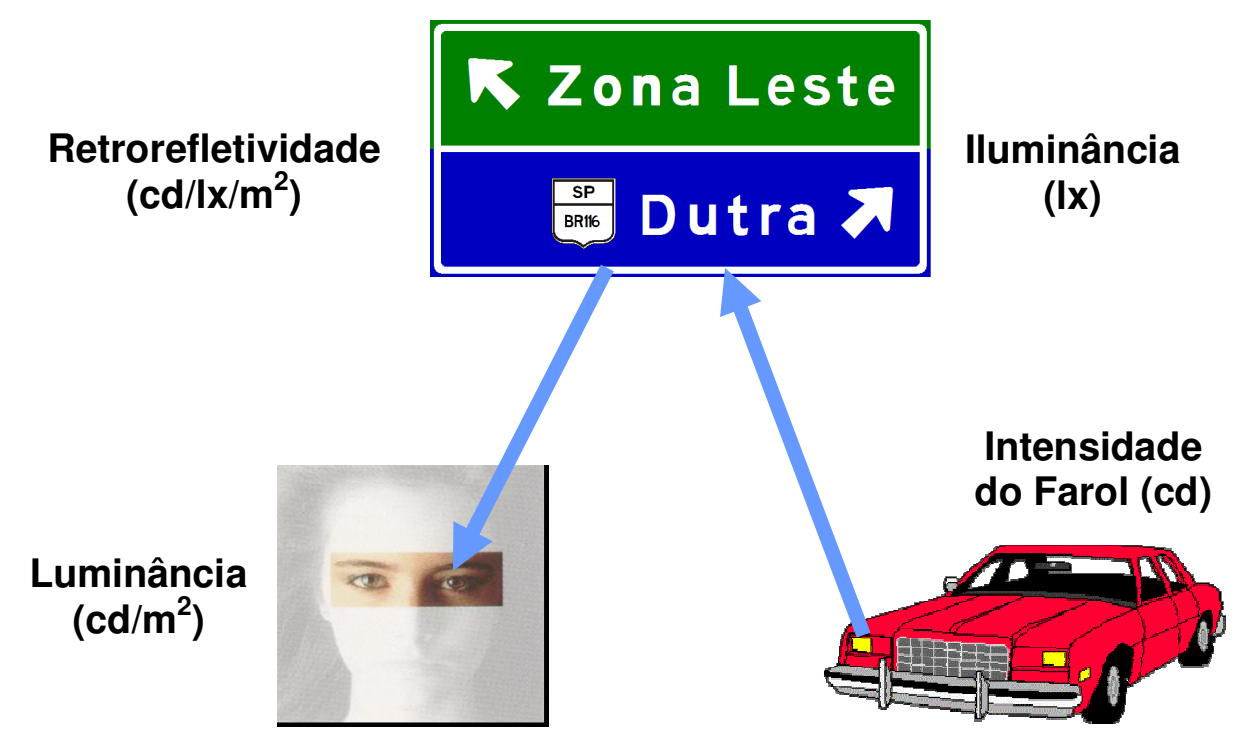

Figura 3.1 - Ilustração dos fatores que afetam a visibilidade e a legibilidade das placas verticais de trânsito. Fonte: Ilustração feita pelo autor.

Obviamente que a idade do motorista e o tipo de veículo (carro passeio, caminhonete, caminhão) influem na quantidade de luminância necessária para que o sinal de trânsito seja percebido, reconhecido e lido.

Santos (1994) coloca que os sinais usados para controle de tráfego atraem somente de $15 \%$ a $20 \%$ do total de atenção dos motoristas.

Moraes (2002) diz que com o veículo em movimento, o motorista deve ser capaz de formar a imagem a todo instante dentro das limitações do pára-brisa do automóvel, obrigando-o a concentrar a fixação do seu olhar numa pequena área do seu campo visual. O motorista, por uma questão de costume e para ganhar tempo, 
concentra a fixação do seu olhar onde ele espera encontrar informações importantes para o desempenho de suas tarefas.

Segundo pesquisa realizada pela CNT (2007), foi encontrado o seguinte cenário das rodovias brasileiras (87.592 km avaliados):

- 54,5\% têm o pavimento em estado regular, ruim ou péssimo (47.777 km);

- $65,4 \%$ têm problemas de sinalização $(57.253 \mathrm{~km})$;

- $8,5 \%$ têm placas total ou parcialmente cobertas por mato ( $7.462 \mathrm{~km})$;

- $39,0 \%$ têm placas com a legibilidade deteriorada $(31.880 \mathrm{~km})$;

- 37,5\% não possuem placas de limite de velocidade (32.815 km);

- $42,5 \%$ não têm acostamento (37.259 km).

Ferraz et al. (1997) apontam à existência dos seguintes problemas relativos à sinalização viária na maioria das cidades brasileiras:

- Alguns sinais de trânsito padronizados pelo Manual Brasileiro de Sinalização de Trânsito (CONTRAN) apresentam baixo impacto visual. Com freqüência os condutores não percebem a existência de algumas placas, mesmo quando os requisitos de tamanho, localização e posição são adequadamente atendidos. Isso é agravado por falta de manutenção;

- Placas de trânsito fixadas em postes comuns destinados à sustentação de cabos aéreos despertam menos a percepção em relação aquelas colocadas em postes próprios. O impacto visual é ainda melhor quando os postes próprios são coloridos (prática adotada em várias cidades, e que, paradoxalmente, contraria a determinação oficial de que os suportes das placas devem ter a cor neutra Código de Trânsito Brasileiro);

- Algumas cidades exageram na colocação de placas, achando que com isso resolvem os problemas de trânsito. Conseqüência: a proliferação de placas acaba por prejudicar a percepção dos próprios sinais de trânsito, além de atuar de forma negativa no que concerne à harmonia e estética do ambiente urbano; 
- Não há nenhuma preocupação com o conjunto placa-suporte. Nesse sentido, vale lembrar que o bonito, em geral, chama mais atenção do que o feio. E placa de trânsito foi feita para chamar a atenção (conspicuidade);

- A percepção dos sinais de trânsito é bastante prejudicada pela proliferação das placas móveis de propaganda comercial que são colocadas nas calçadas (passeios) das vias urbanas.

Mori e Abdel-Halin (1981) em seus estudos sobre o movimento dos olhos dos motoristas, concluíram que os motoristas prestam muito pouca atenção no sistema de sinais de trânsito.

Mise (2000), Fontana (2001) e Moraes (2002) apontaram a importância de realizar mais avaliações sobre o layout e os suportes dos sinais de trânsito utilizados em algumas cidades do Brasil, que são mais conspícuos que os padronizados. No entanto, nenhum desses estudos apresentou avaliações noturnas e dinâmicas dos sinais de trânsito, somente em situação de laboratório, ou seja estática, e os resultados partiram de pequenas amostras, representando somente tendências de escolha.

Cole e Jenkins (1982) estudaram a estimativa de conspicuidade dos dispositivos de sinalização de trânsito vistos em cenários de trânsito comuns e, também, as características desses objetos relacionadas à conspicuidade. Foi concluído que o tamanho e a definição das extremidades do sinal são muito importantes, e que os sinais em cor branca são mais notados que os coloridos, em função do alto fator de retrorrefletância da cor. E definiram "um objeto conspícuo é aquele que chama a atenção e não precisa ser procurado para ser notado".

De acordo com o resultado da primeira semana do Programa de Inspeção Veicular Gratuito realizado na capital paulista, 40\% dos carros avaliados tinham problemas de iluminação e $27 \%$ problemas nos limpadores de pára-brisas, o que dificulta ainda mais a visualização correta dos sinais de trânsito. 
De acordo com a Fundação Royal Automobile Club (2004), com sede em Londres, na Inglaterra, foi promovido um estudo que apontou os veículos brancos com menos possibilidades de se envolver em um acidente de trânsito. Pois, quanto mais claro for o carro, maior a capacidade de chamar a atenção do motorista.

De acordo com o Departamento de Administração Rodoviária Federal dos Estados Unidos - FHWA (2003), os valores da luminância dos sinais verticais de trânsito variam entre $3,4 \mathrm{~cd} / \mathrm{m}^{2}$ e $340 \mathrm{~cd} / \mathrm{m}^{2}$; podendo ser considerado ótimo para a maioria das rodovias valores entre $34 \mathrm{e} 102 \mathrm{~cd} / \mathrm{m}^{2}$. A placa de sinalização deve ter um desalinhamento de 5 graus em relação ao eixo da pista, pois assim deixa de existir o efeito especular na placa (brilho muito intenso que torna a placa ilegível). A FHWA (2003) após vários estudos definiu como valores mínimos de retrorrefletividade dos sinais verticais de trânsito aqueles mencionados na Tabela 3.2 .

Tabela 3.2 - Valores mínimos de retrorrefletividade dos sinais verticais de trânsito

\begin{tabular}{|c|c|c|c|c|c|c|c|}
\hline \multirow{2}{*}{ COR SINAL } & \multirow{2}{*}{ CRITÉRIO } & \multicolumn{6}{|c|}{ PELÍCULA REFLETIVA (ASTM D 4956) } \\
\hline & & $I^{*}$ & II* & III* & VII* & VIII* & IX* \\
\hline $\begin{array}{l}\text { Branco no } \\
\text { Vermelho }\end{array}$ & Veja nota 1 & \multicolumn{6}{|c|}{$35 / / 7$} \\
\hline \multirow{2}{*}{$\begin{array}{l}\text { Preto no Laranja } \\
\text { ou Amarelo }\end{array}$} & Veja nota 2 & $\mathrm{X}$ & \multicolumn{5}{|c|}{50} \\
\hline & Veja nota 3 & $\mathrm{X}$ & \multicolumn{5}{|c|}{75} \\
\hline Preto no Branco & - & \multicolumn{6}{|c|}{50} \\
\hline \multirow{2}{*}{ Verde no Branco } & Suspenso & $\mathrm{x} / / 7$ & $\mathrm{x} / / 15$ & $x / / 25$ & \multicolumn{3}{|c|}{$250 / / 25$} \\
\hline & Chão (lateral) & $\mathrm{x} / / 7$ & \multicolumn{5}{|c|}{$120 / / 15$} \\
\hline \multicolumn{8}{|c|}{$\begin{array}{l}\text { NOTAS: } \\
\text { Os números nas células representam retrorrefletividade da legenda } / / \text { retrorrefletividade } \\
\text { fundo (para sinais de contraste positivo). Medidas em cd/lux } / \mathrm{m}^{2}\left(0,2^{0} \mathrm{e}-4^{0}\right) \text {. } \\
1 \text { - Contraste mínimo } \geq 3: 1 \text { (branco } \div \text { vermelho) } \\
2 \text { - Para textos em placas com tamanho de } 1,22 \mathrm{~m} \text { ou mais e letras em negrito. } \\
3 \text { - Para textos em placas com tamanho menos de } 1,22 \mathrm{~m} \text { e letras finas. } \\
\text { x - Este tipo de película retrorrefletiva não deve ser utilizada } \\
\text { * - Tipo de película refletiva (os menores valores romanos equivalem a películas com } \\
\text { menores grau de refletividade), conforme norma ASTM D } 4956 \text {. }\end{array}$} \\
\hline
\end{tabular}

A Norma Brasileira que trata dos requisitos das películas retrorrefletivas para sinalização viária vertical é a NBR 14.644; nela são definidos os materiais, as 
tecnologias utilizadas e os índices de retrorrefletividade. A Norma Americana que trata deste mesmo assunto nos Estados Unidos é a ASTM D 4.956.

A NBR 14.644 especifica os materiais de acordo com sua base de construção tecnológica, sua capacidade refletiva e durabilidade, conforme Tabela 3.3.

Tabela 3.3 - Tipos de materiais retrorrefletivos dos sinais verticais de trânsito

\begin{tabular}{|c|c|c|c|c|}
\hline \multirow{2}{*}{$\begin{array}{c}\text { Base } \\
\text { Tecnológica }\end{array}$} & Tipo de Película & Nome Comercial & $\begin{array}{c}\text { Durabilidade } \\
\text { (anos) }\end{array}$ & $\begin{array}{c}\text { Retenção da } \\
\text { retrorrefletividade* } \\
\text { (\% em relação à inicial) }\end{array}$ \\
\hline \multirow{3}{*}{$\begin{array}{c}\text { Micro } \\
\text { Esferas de } \\
\text { Vidro }\end{array}$} & Tipo IA & $\begin{array}{c}\text { Grau Técnico ou Grau } \\
\text { Engenharia }\end{array}$ & 7 & $50 \%$ \\
\cline { 2 - 5 } & Tipo IB & $\begin{array}{c}\text { Super Grau } \\
\text { Engenharia }\end{array}$ & 10 & $50 \%$ \\
\hline \multirow{4}{*}{ Prismática } & Tipo II & $\begin{array}{c}\text { Alta Intensidade } \\
\text { Encapsulado }\end{array}$ & 10 & $80 \%$ \\
\cline { 2 - 5 } & Tipo III & $\begin{array}{c}\text { Alta Intensidade } \\
\text { Prismática }\end{array}$ & 10 & $80 \%$ \\
\cline { 2 - 5 } & Tipo VI & $\begin{array}{c}\text { Obras } \\
\text { (Elastomérica) }\end{array}$ & 3 & $80 \%$ \\
\cline { 2 - 5 } & Tipo VII & $\begin{array}{c}\text { Grau Diamante LDP } \\
\text { ou Prismática MVP }\end{array}$ & 10 & $80 \%$ \\
\cline { 2 - 5 } & Tipo IX & $\begin{array}{c}\text { Conspicuity } \\
\text { Metalizado }\end{array}$ & 10 & $80 \%$ \\
\cline { 2 - 5 } & Tipo X & Grau Diamante & 10 & $80 \%$ \\
\hline
\end{tabular}

* Retenção de retrorrefletividade no final da vida útil.

Fonte: NBR 14644

A NBR 14.644 também especifica que os caracteres na cor preta devem ser de material não refletivo para proporcionar contraste com as outras cores (preto legenda - tipo IV). A película Tipo IV (preto legenda) não possui retrorrefletividade pois no período noturno ela deve manter a mesma cor que possui no período diurno (preto).

Além disso, esta norma especifica as retrorrefletividades mínimas iniciais para todas as cores padronizadas de sinalização viária. A Tabela 3.4, mostra a retrorrefletividade nos ângulos de $0,2^{0}$ de observação e $-4^{0}$ de entrada, sendo estes os ângulos mais comumente utilizados, pois representam na prática os ângulos no momento em que a pessoa esta fazendo a leitura da placa. 
Tabela 3.4 - Retrorrefletividade mínima inicial das películas de sinalização viária

\begin{tabular}{|c|c|c|c|c|c|c|c|c|c|c|}
\hline \multirow{2}{*}{$\begin{array}{l}\text { Tipo de } \\
\text { Película }\end{array}$} & \multicolumn{10}{|c|}{$\begin{array}{c}\left.\text { Retrorrefletividade inicial (cd/lux/m² a } 0,2^{0} \mathrm{e}-4^{0}\right) \\
\text { CORES PADRONIZADAS DE SINALIZAÇÃO }\end{array}$} \\
\hline & Branca & Amarela & Laranja & Verde & Vermelha & Azul & Marrom & $\begin{array}{c}\text { Amarela } \\
\text { lima-limão } \\
\text { fluorescente }\end{array}$ & $\begin{array}{c}\text { Amarela } \\
\text { fluorescente }\end{array}$ & $\begin{array}{c}\text { Laranja } \\
\text { fluorescente }\end{array}$ \\
\hline Tipo IA & 70 & 50 & 25 & 9 & 14 & 4 & 1 & - & - & - \\
\hline Tipo IB & 140 & 100 & 60 & 30 & 30 & 10 & 5 & - & - & - \\
\hline Tipo II & 250 & 170 & 100 & 45 & 45 & 20 & 12 & - & - & - \\
\hline Tipo III & 360 & 270 & 145 & 50 & 65 & 30 & 18 & 290 & 220 & 105 \\
\hline Tipo VI & 500 & 350 & 125 & 60 & 70 & 45 & - & 400 & 300 & 200 \\
\hline Tipo VII & 700 & 525 & 265 & 70 & 105 & 42 & 21 & 480 & 375 & 200 \\
\hline Tipo VIII & 700 & 470 & 280 & 120 & 120 & 56 & - & - & - & - \\
\hline Tipo IX & 380 & 285 & 145 & 38 & 76 & 17 & - & 300 & 230 & 115 \\
\hline Tipo X & 425 & 395 & 210 & 52 & 106 & 26 & - & 420 & 330 & 165 \\
\hline
\end{tabular}

Fonte: NBR 14.644

Os diversos tipos de películas são caracterizados pelos diferentes valores da refletividade. Quanto maior o índice de refletividade, mais "brilhante" é a película e, em conseqüência, maior a eficiência do retorno da luz incidente do farol aos olhos do motorista.

Observa-se que no Brasil, os materiais mais comumente utilizados na sinalização viária são:

- Vias urbanas:

- Placas de Regulamentação e Advertência:

- Placa com fundo pintado com tinta semi-brilho e caracteres (letras, tarjas e símbolos) em película vinílica não refletiva;

- Placa com fundo em película refletiva tipo IA e caracteres (letras, tarjas e símbolos) em película refletiva tipo IA).

- Placas Indicativas:

- Placa com fundo pintado com tinta semi-brilho e caracteres (letras, tarjas e símbolos) em película vinílica não refletiva; 
- Placa com fundo pintado com tinta semi-brilho e caracteres (letras, tarjas e símbolos) em película refletiva tipo IA;

- Placa com fundo em película refletiva tipo IA e caracteres (letras, tarjas e símbolos) em película refletiva tipo IA);

- Placa com fundo em película refletiva IA e caracteres (letras, tarjas e símbolos) em película refletiva tipo III).

- Rodovias não concessionadas:

- Placas de Regulamentação e Advertência:

- Placa com fundo pintado com tinta semi-brilho e caracteres (letras, tarjas e símbolos) em película refletiva tipo IA;

- Placa com fundo em película refletiva tipo IA e caracteres (letras, tarjas e símbolos) em película refletiva tipo IA.

- Placas Indicativas:

- Placa com fundo pintado com tinta semi-brilho e caracteres (letras, tarjas e símbolos) em película refletiva tipo IA;

- Placa com fundo em película refletiva tipo IA e caracteres (letras, tarjas e símbolos) em película refletiva tipo IA;

- Placa com fundo em película refletiva tipo IA e caracteres (letras, tarjas e símbolos) em película refletiva tipo III.

- Rodovias concessionadas:

- Placas de Regulamentação e Advertência:

- Placa com fundo em película refletiva tipo III e caracteres (letras, tarjas e símbolos) em película refletiva tipo III;

- Placa com fundo em película refletiva tipo X e caracteres (letras, tarjas e símbolos) em película refletiva tipo X;

- Placas Indicativas:

- Placa com fundo em película refletiva tipo IA e caracteres (letras, tarjas e símbolos) em película refletiva tipo IA; 
- Placa com fundo em película refletiva tipo IA e caracteres (letras, tarjas e símbolos) em película refletiva tipo III;

- Placa com fundo em película refletiva tipo III e caracteres (letras, tarjas e símbolos) em película refletiva tipo X;

- Placa com fundo em película refletiva tipo X e caracteres (letras, tarjas e símbolos) em película refletiva tipo X.

Mace et al. (1994) concluiu que a idade do motorista é o fator mais relevante na conspicuidade e na legibilidade da sinalização. Outros fatores que se mostraram significantes são: retrorrefletividade, tipo de letra e altura da letra. Mace ainda verificou a relação distância de legibilidade e a altura das letras nas placas de sinalização, relacionadas com a idade da pessoa: para jovens $6,0 \mathrm{~m} / \mathrm{cm}$ de altura de letra; para idosos $4,8 \mathrm{~m} / \mathrm{cm}$ de altura de letra. Pode-se exemplificar este fato utilizando uma placa de nome de rua, de $10 \mathrm{~cm}$ de altura de letra. Uma pessoa jovem conseguirá visualizar (iniciar a leitura) o texto desta placa de sinalização a 60 metros de distância da placa, enquanto que uma pessoa idosa conseguirá visualizar o mesmo texto da placa a uma distância de 48 metros. Estas distâncias são extremamente importantes, pois dependendo da velocidade do veículo, ela será fundamental para leitura e compreensão da informação contida na placa com posterior execução de uma manobra segura.

Sivak e Olson (1985) estudaram a sinalização de nome de rua e chegaram a conclusão que para se ter uma legibilidade adequada as alturas das letras nas placas de nome de rua devem ser de $15 \mathrm{~cm}$ para placas utilizadas nas esquinas das ruas e de $20 \mathrm{~cm}$ para as placas suspensas no braço do semáforo.

Morales (1987) publicou um trabalho relacionado aos requisitos de retrorrefletividade do sinal de regulamentação PARE. Morales desenvolveu um procedimento onde a retrorrefletividade é o resultado dependente da velocidade e do tamanho da placa. Para determinar a retrorrefletividade mínima, Morales multiplicou a retrorrefletividade da cor vermelha por 0,76 e a retrorrefletividade da cor branca 
por 0,24, e somando-as chegou a um valor único de retrorrefletividade para a placa em questão. Em seu experimento, foi testado um sinal PARE de $80 \mathrm{~cm}$, instalado em rodovia cuja velocidade regulamentada era $80 \mathrm{~km} / \mathrm{h}$. Morales chegou à conclusão que o valor mínimo de retrorrefletividade recomendado para esta placa de sinalização é $40 \mathrm{~cd} / \mathrm{lux} / \mathrm{m}^{2}$.

Baseado em estudos de Mace et al. (1985), pesquisadores recomendam que sinais de Advertência e Regulamentação tenham os seguintes valores mínimos de retrorrefletividade:

- $18 \mathrm{~cd} / \mathrm{lux} / \mathrm{m}^{2}$ - para ambientes de pouca complexibilidade.

- $36 \mathrm{~cd} / \mathrm{lux} / \mathrm{m}^{2}$ - para ambientes de alta complexibilidade.

Estudos realizados na Austrália em 1991 chegaram à conclusão que os sinais de regulamentação e advertência tem que ter 3 vezes mais refletividade do que os sinais de indicação. Estudos de laboratório indicaram o valor mínimo de luminância de $9,7 \mathrm{~cd} / \mathrm{m}^{2}$ para os sinais de regulamentação e advertência, sendo que os demais sinais o valor mínimo deve ser de $3,2 \mathrm{~cd} / \mathrm{m}^{2}$.

Carlson e Hawkings (2003) estudaram os sinais suspensos e os sinais de nome de rua, relacionando a legibilidade em função do material retrorrefletivo usado, a velocidade da via e o posicionamento deste na via. Concluíram que os materais refletivos de alta performance (prismáticos) são os mais indicados para ambas as situações.

Além dos valores de retrorrefletividade, outros fatores estão diretamente ligados com a legibilidade de uma placa de sinalização. Tendo isto em mente, foram mapeados os dois principais tipos de lâmpadas existentes, conforme Figura 3.2, para assim ter uma melhor visualização da distribuição da luz no ambiente viário. 


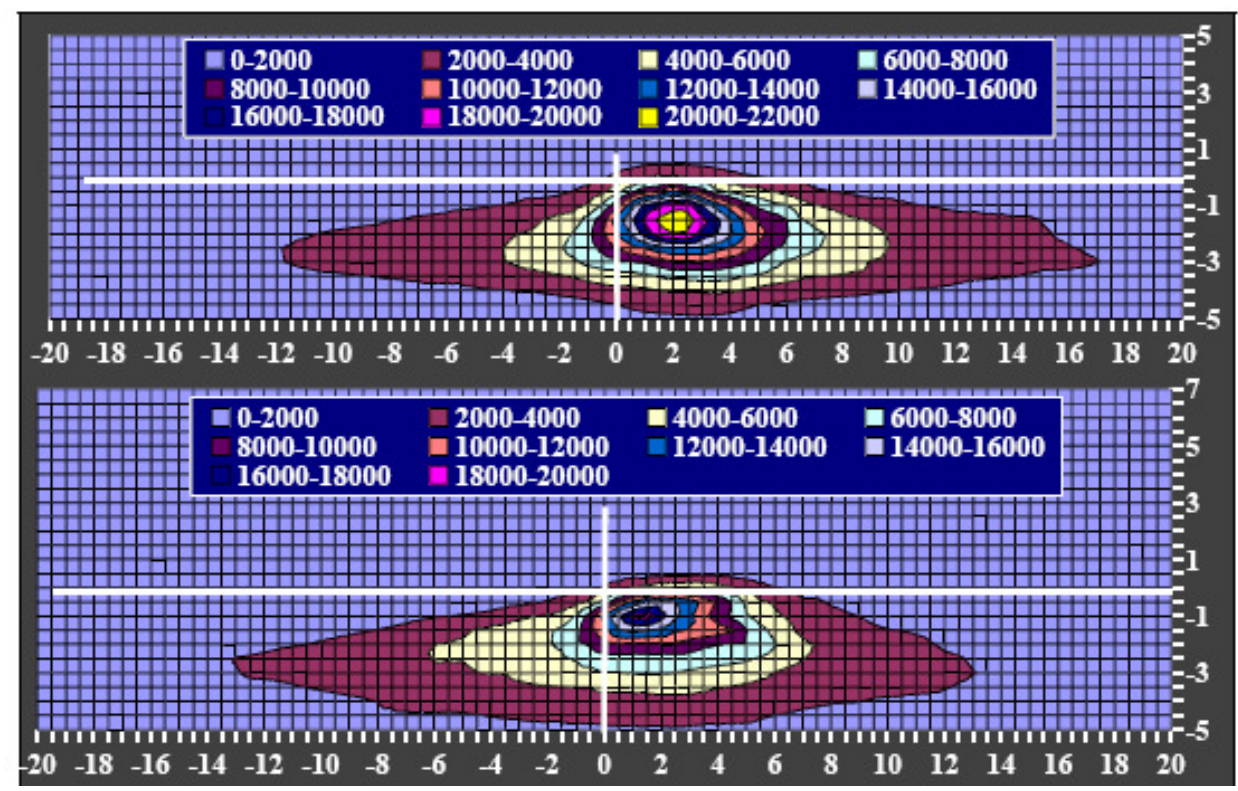

Figura 3.2 - Medições de Candelas das lâmpadas CARTS50(superior) e UMTRI25PC(inferior). Fonte: Carlson e Hawking (2003)

Analisando a Figura 3.2, pode-se concluir que a maior concentração de intensidade luminosa esta focada mais no centro do veículo e no chão, com valores de até 22.000 candelas. Entretanto, a Sinalização Vertical Viária é implantada numa área onde os valores são muito menores, com valores entre 0 a 2.000 candelas para placas suspensas ou aéreas.

A Organização Holandesa de Estudos Científicos Aplicados - TNO (2000) estudando os faróis dos veículos e a localização das placas no sistema viário constatou que a placa que mais recebe intensidade luminosa é a placa que fica a direita do motorista (estando este na faixa da direita da via). Assim, tendo esta placa como base $(100 \%)$ foi criada uma ilustração da quantidade de luz que as outras placas recebem se comparado com ela, conforme mostrado na Figura 3.3. 


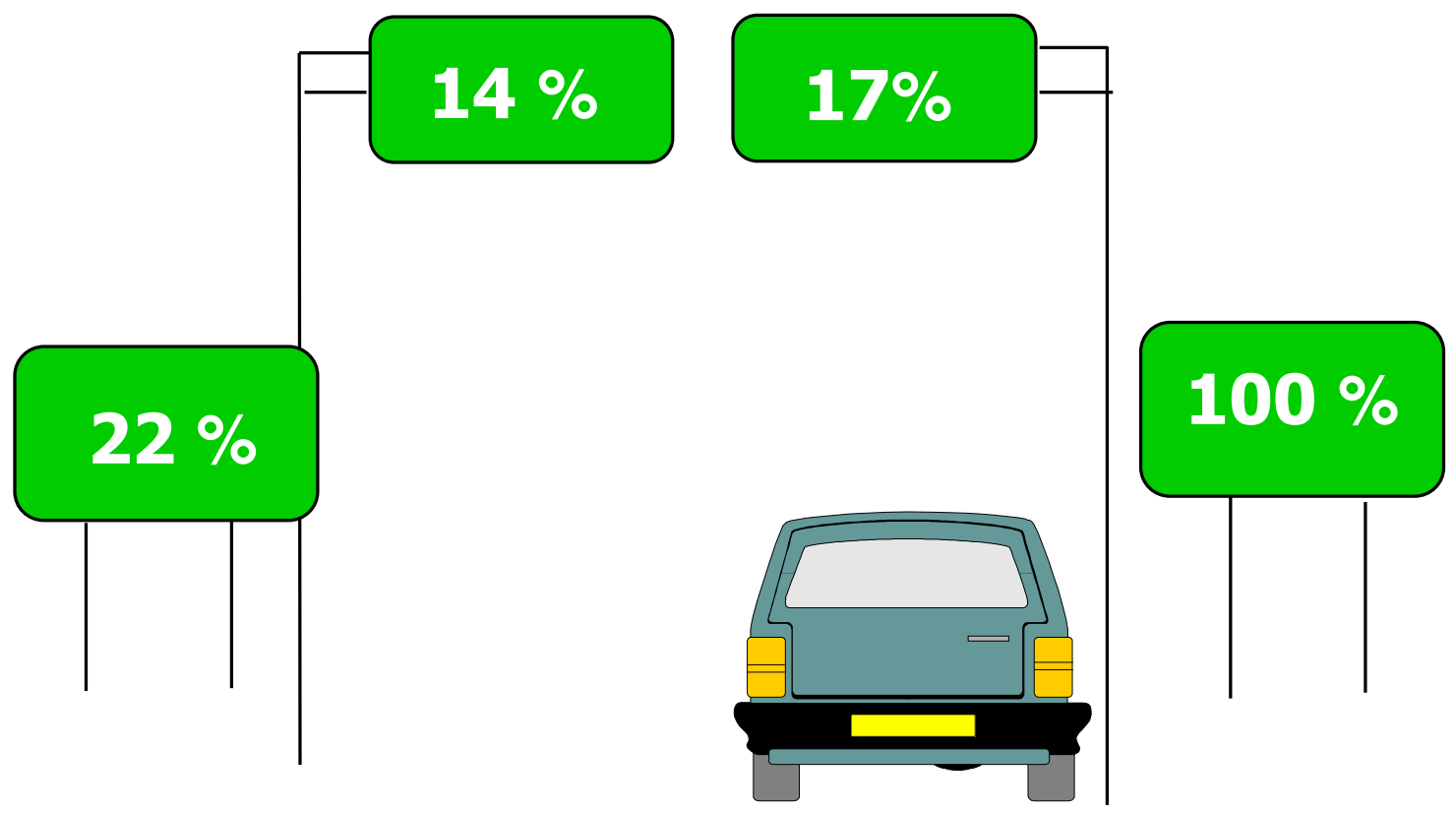

Figura 3.3 - Performance do Sinal x Posicionamento. Fonte: TNO (2000).

Analisando a Figura 3.3 conclui-se que para as rodovias de pista dupla as placas aéreas precisam de um material 6 vezes mais retrorrefletivo do que a placa instalada à direita. E a placa instalada à esquerda precisa de um material 4 vezes mais retrorrefletivo. Isso criaria um sistema de visualização uniforme para o motorista que esteja trafegando na faixa da direita em uma rodovia de pista dupla. 


\section{4 \\ MÉTODO DE COMPARAÇÃO AOS PARES DA PSICOFÍSICA}

\subsection{PSICOFÍSICA}

A definição mais antiga de Psicofísica foi apresentada por Gustav Theodor Fechener, em 1980, com sendo "uma ciência exata da relação ou relações funcionais de dependência entre o corpo e o espírito". Modernamente a Psicofísica tem sido definida como "o estudo científico das relações entre propriedades físicas dos estímulos e as correspondentes experiências psicológicas bem como as razões de tais relações" (Da Silva, apud Kawamoto 1987).

A Psicofísica consegue mensurar a sensação experimentada por pessoas quando elas são submetidas à análise, sendo mensurado através de suas respostas. Esta análise pode ser feita individualmente ou em grupo, dependendo do método e das características do experimento.

Segundo Da Silva e Rozestraten (2000), os tipos de pesquisas experimentais são três:

Pesquisas de Laboratório - São aquelas realizadas em locais apropriados onde o pesquisador tem a capacidade de controlar qualquer variável independente, de acordo com a sua necessidade de avaliação. Podem ser consideradas variáveis independentes: ruídos, odores, luminosidade, etc.

Pesquisas de Campo ou Estrada - Como o próprio nome diz são aquelas pesquisas realizadas em ambientes naturais onde o sujeito esta totalmente ou parcialmente exposto as variáveis independentes, portanto mais difíceis de serem controladas pelo pesquisador. 
Simulações - São aquelas pesquisas realizadas com o auxílio de algum aparato tecnológico que simule uma situação real. Podem ser citados como exemplos os simuladores de avião comercial utilizados pelas companhias aéreas para treinamento de pilotos.

Existe uma grande quantidade diferente de métodos de avaliação psicofísica, dentre eles pode-se citar: Método de Comparação ao Pares, Método de Ordenação (Rank Order), Método dos Limites, Método de Estimativa de Magnitude, Método de Multidimensionalidade, entre outros.

\subsection{MÉTODO DE COMPARAÇÃO AOS PARES}

Este método consiste basicamente em comparar os estímulos em pares, fazendo com que todos sejam comparados entre si.

Da Silva e Rozestraten (2000) colocam que no Método de Comparação aos Pares todos os estímulos são comparados entre si. Dessa forma, além de saber quais são os melhores, pode-se também saber o quanto "melhor" é cada estímulo em relação aos demais. Devido ao alto grau de confiabilidade, este método serve inclusive para confirmar ou não resultados obtidos por outros métodos.

Inicialmente todos os estímulos são julgados e comparados com os demais, conduzindo a um número $\mathrm{x}$ de pares de estímulos conforme mostra a equação 1.

Equação 1: $\mathrm{x}=\mathrm{n} *(\mathrm{n}-1) / 2$

Sendo x número de pares de estímulos e n número de estímulos.

A avaliação dos dados obtidos nas comparações é realizada através do escore "z" (obtido através da curva de distribuição normal), que possibilita uma maior apuração e elaboração da escala dos estímulos, sendo possível saber qual estímulo 
apresenta mais de determinada característica e também o quanto dessa característica ele apresenta em relação aos demais.

Para exemplificar a utilização do método de comparação aos pares foi solicitado a um grupo de 10 estudantes para escolherem qual o seu carro favorito, sendo que os carros são apresentados aos pares (um contra o outro). Os carros são Ferrari, Porshe, Volvo e Jaguar. A Tabela 4.1 apresenta as escolhas feitas pelos estudantes entrevistados.

Tabela 4.1 - Escolhas realizadas pelos estudantes no experimento dos carros

\begin{tabular}{|c|c|c|c|c|}
\hline & Porshe & Volvo & Ferrari & Jaguar \\
\hline Porshe & - & 8 & 2 & 9 \\
\hline Volvo & 2 & - & 4 & 7 \\
\hline Ferrari & 8 & 6 & - & 7 \\
\hline Jaguar & 1 & 3 & 3 & - \\
\hline
\end{tabular}

O número das células representa quantos estudantes preferiram o carro da linha em detrimento do carro que aparece na coluna onde está o número. Por exemplo: quando solicitados para escolher entre os carros Ferrari e Porshe, 8 estudantes preferiram a Ferrari e 2 a Porshe.

A etapa seguinte consiste em transformar os valores absolutos em porcentagens, sendo que onde o carro da linha é o mesmo carro da coluna o valor atribuído é 50\%. Os valores obtidos são mostrados na Tabela 4.2.

Tabela 4.2 - Percentuais de escolhas dos carros

\begin{tabular}{|c|c|c|c|c|}
\hline & Porshe & Volvo & Ferrari & Jaguar \\
\hline Porshe & $50 \%$ & $80 \%$ & $20 \%$ & $90 \%$ \\
\hline Volvo & $20 \%$ & $50 \%$ & $40 \%$ & $70 \%$ \\
\hline Ferrari & $80 \%$ & $60 \%$ & $50 \%$ & $70 \%$ \\
\hline Jaguar & $10 \%$ & $30 \%$ & $30 \%$ & $50 \%$ \\
\hline
\end{tabular}

Em seguida são obtidos os valores de $\mathrm{z}$ correspondentes as porcentagens obtidas com base em uma tabela de valores de uma Distribuição Normal com média igual a 0 e variância igual a 1 . No exemplo dos carros, os valores de $\mathrm{z}$ correspondentes as porcentagens de escolha feitas pelos sujeitos são indicados na Tabela 4.3. 
Tabela 4.3 - Escores z correspondentes aos percentuais obtidos no exemplo dos carros

\begin{tabular}{|c|c|c|c|c|c|c|c|c|c|}
\hline Percentual & $\mathbf{1 0 \%}$ & $\mathbf{2 0 \%}$ & $\mathbf{3 0 \%}$ & $\mathbf{4 0 \%}$ & $\mathbf{5 0 \%}$ & $\mathbf{6 0 \%}$ & $\mathbf{7 0 \%}$ & $\mathbf{8 0 \%}$ & $\mathbf{9 0 \%}$ \\
\hline Escore z & $-1,28$ & $-0,84$ & $-0,52$ & $-0,25$ & 0,00 & 0,25 & 0,52 & 0,84 & 1,28 \\
\hline
\end{tabular}

Com a obtenção dos valores de $\mathrm{z}$ associados as diversas porcentagens que representam as escolhas entre os pares de opções, é calculada a média aritmética dos valores de z, como mostrado na Tabela 4.4.

A partir do valor das médias resultantes, é determinada a "escala ajustada", determinada estabelecendo um valor igual a zero para o menor $\mathrm{z}$ médio e somandose o valor de z médio mínimo aos outros valores médios de z com sinal contrário, como mostrado na Tabela 4.4.

Com a escala ajustada dos valores médios de z é possível classificar os estímulos, ou seja, ordená-los. Assim, quanto maior o valor médio de z melhor a sua classificação, como mostrado na última coluna da Tabela 4.4.

Tabela 4.4 - Escores z médios, ajustados e ordenados

\begin{tabular}{|l|c|c|c|c|c|c|c|}
\hline & Porshe & Volvo & Ferrari & Jaguar & Média & $\begin{array}{c}\text { Escala } \\
\text { Ajustada }\end{array}$ & ORDEM \\
\hline Porshe & 0,00 & 0,84 & $-0,84$ & 1,28 & 0,32 & 0,90 & $\mathbf{2}^{\mathbf{0}}$ \\
\hline Volvo & $-0,84$ & 0,00 & $-0,25$ & 0,52 & $-0,14$ & 0,44 & $\mathbf{3}^{\mathbf{0}}$ \\
\hline Ferrari & 0,84 & 0,25 & 0,00 & 0,52 & 0,40 & 0,98 & $\mathbf{1}^{\mathbf{0}}$ \\
\hline Jaguar & $-1,28$ & $-0,52$ & $-0,52$ & 0,00 & $-0,58$ & 0,00 & $\mathbf{4}^{\mathbf{0}}$ \\
\hline
\end{tabular}




\section{5 \\ EXPERIMENTOS REALIZADOS}

\subsection{LOCAL DOS EXPERIMENTOS}

Os experimentos foram realizados na Sala de Demonstração Noturna, instalada no CTC (Centro Tecnológico de Clientes) da 3M do Brasil, na cidade de Sumaré - SP.

Optou-se por esta sala porque apresenta características ideais de baixa luminosidade, ausência de ruídos (poluição sonora) e climatização satisfatória. $\mathrm{O}$ objetivo da coleta de dados neste local é de eliminar as variáveis independentes e submeter todos os sujeitos às mesmas condições para análise dos estímulos propostos.

A sala possui aproximadamente 15 metros de comprimento por 3,5 metros de largura e 3,5 metros de altura (pé-direito). O interior é pintado na cor preta (evitando-se assim o reflexo de iluminação). A vedação nas portas e os vidros também são pretos, tornando a sala totalmente escura. A iluminação é totalmente controlada em um painel, podendo-se, assim, variar a intensidade luminosa.

Em um lado da sala, existem três fileiras de cinco cadeiras, dispostas lado a lado, conforme ilustrado na Figura 5.1, onde as pessoas que participam do experimento ficam sentadas. 


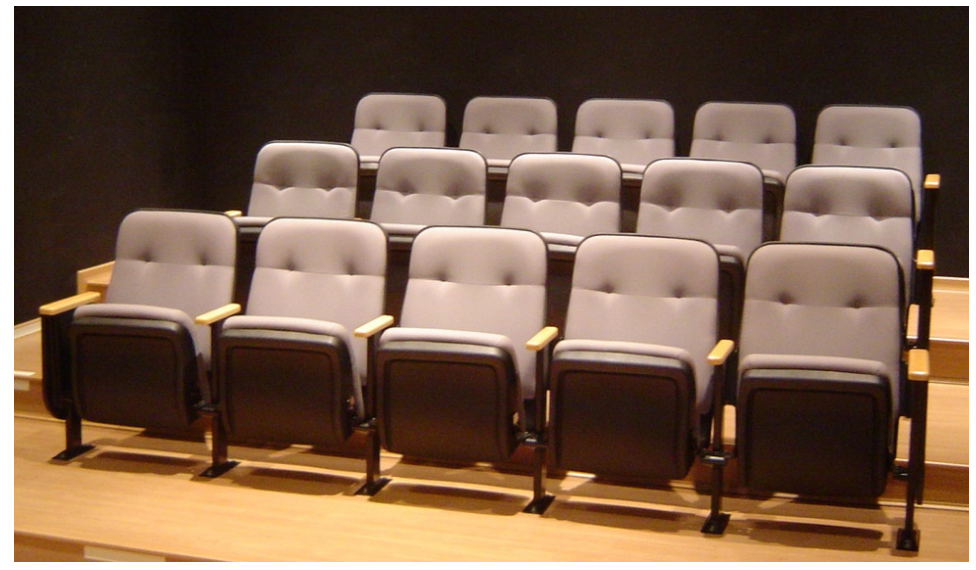

Figura 5.1 - Foto do local do experimento. Fonte: Imagem editada pelo autor.

No fundo da sala existe um espelho no qual a imagem é visualizada. Esta visualização se dá através de imagens refletidas em dois espelhos e uma mesa de apoio, na qual os sinais são colocados para serem comparados, conforme mostrado na Figura 5.2. Fontes luminosas com direcionamento exato simulam situações de iluminação como: diurno (ambiente todo iluminado), noturno (ambiente todo escuro e uma fonte de luz simulando o farol de um veículo) e noturno com iluminação superior a placa (ambiente escurecido com uma fonte de luz simulando o farol de um veículo e uma luz sobre a placa).

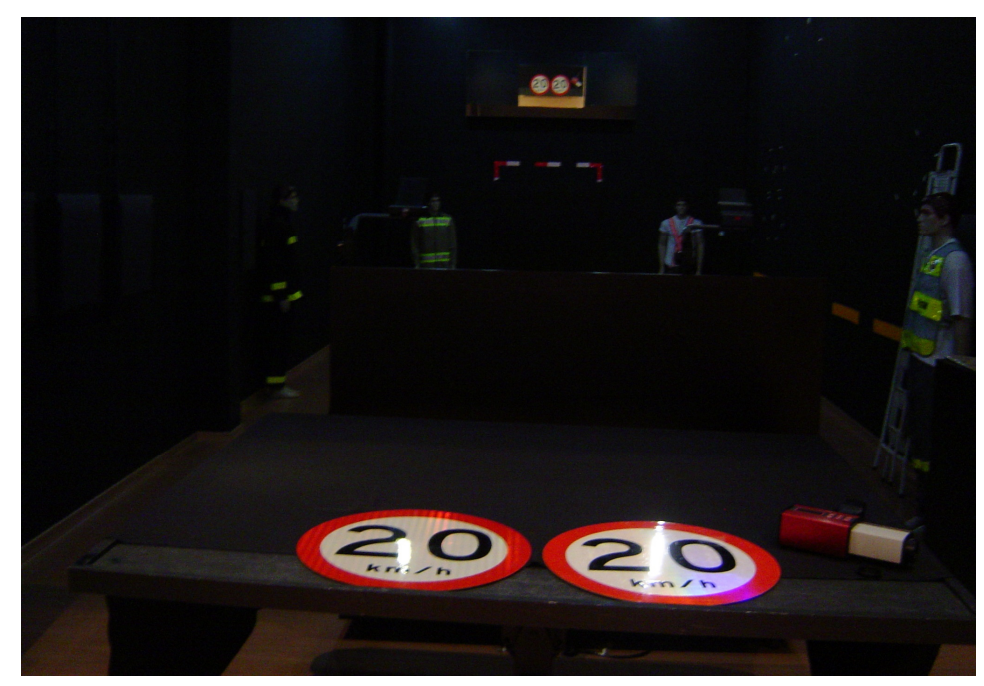

Figura 5.2 - Foto do local onde eram observados os experimentos. Fonte: Imagem editada pelo autor. 


\subsection{MATERIAIS UTILIZADOS}

Os experimentos foram realizados com os materiais mais comumente utilizados na confecção das placas de sinalização viária no Brasil, conforme segue:

- Placas de regulamentação (R 19 - 20 km/h) - ilustração na Figura 5.3.

- Tamanho: diâmetro de $50 \mathrm{~cm}$.

- Substrato: poliéster reforçado com fibra de vidro.

- Verso da placa: cor preta.

- Frente da placa: conforme especificado na Tabela 5.1.

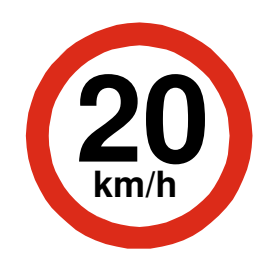

Figura 5.3 - Modelo de placa de regulamentação utilizada. Fonte: Imagem editada pelo autor.

Tabela 5.1 - Tipos de placas de regulamentação pesquisados em função do material empregado

\begin{tabular}{|c|c|c|}
\hline TIPO & CARACTERES & FUNDO \\
\hline $\mathbf{1}$ & $\begin{array}{c}\text { Tarja e letras de película vinílica } \\
\text { não refletiva }\end{array}$ & Látex semi-brilho \\
\hline $\mathbf{2}$ & $\begin{array}{c}\text { Tarja e letras de película refletiva } \\
\text { tipo IA }\end{array}$ & Látex semi-brilho \\
\hline $\mathbf{3}$ & $\begin{array}{c}\text { Tarja de película refletiva tipo IA e } \\
\text { letras em película vinílica tipo IV }\end{array}$ & Película refletiva tipo IA \\
\hline $\mathbf{4}$ & $\begin{array}{c}\text { Tarja de película refletiva tipo III e } \\
\text { letras em película vinílica tipo IV }\end{array}$ & Película refletiva tipo III \\
\hline $\mathbf{5}$ & $\begin{array}{c}\text { Tarja de película refletiva tipo X e } \\
\text { letras em película vinílica tipo IV }\end{array}$ & Película refletiva tipo X \\
\hline
\end{tabular}


- Placas de indicação de localidade (Palavra Fórum) - ilustração na Figura 5.4.

- Tamanho: 100 x $50 \mathrm{~cm}$.

- Altura letra: $15 \mathrm{~cm}$ (tendo como base a letra maiúscula).

- Substrato: poliéster reforçado com fibra de vidro.

- Verso da placa: cor preta.

- Frente da placa: conforme especificado na Tabela 5.2.

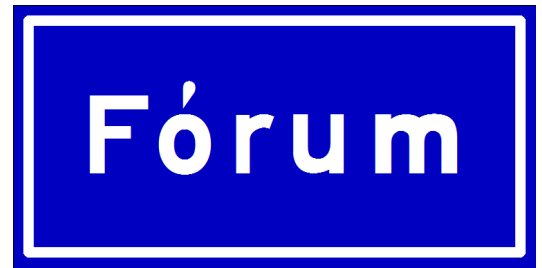

Figura 5.4 - Modelo de placa de identificação de localidade utilizada. Fonte: Imagem editada pelo autor.

Tabela 5.2 - Tipos de placas de indicação pesquisados em função do material utilizado

\begin{tabular}{|c|c|c|}
\hline TIPO & CARACTERES & FUNDO \\
\hline $\mathbf{1}$ & $\begin{array}{c}\text { Tarja e letras em película vinílica } \\
\text { não refletiva }\end{array}$ & Látex semi-brilho \\
\hline $\mathbf{2}$ & $\begin{array}{c}\text { Tarja e letras em película } \\
\text { refletiva tipo IA }\end{array}$ & Látex semi-brilho \\
\hline $\mathbf{3}$ & $\begin{array}{c}\text { Tarja e letras em película } \\
\text { refletiva tipo IA }\end{array}$ & Película refletiva tipo IA \\
\hline $\mathbf{4}$ & $\begin{array}{c}\text { Tarja e letras em película } \\
\text { refletiva tipo III }\end{array}$ & Película refletiva tipo IA \\
\hline $\mathbf{5}$ & $\begin{array}{c}\text { Tarja e letras em película } \\
\text { refletiva tipo X }\end{array}$ & Película refletiva tipo X \\
\hline
\end{tabular}

- Equipamento de medição de retrorrefletividade

$\mathrm{Na}$ medição da retrorrefletividade foi utilizado um equipamento portátil, modelo Retrosign Reflectometer 4000, da marca Delta Light \& Optics (foto do equipamento na Figura 5.5). Este equipamento realiza a medição da retrorrefletividade dos materiais utilizados nas placas de sinalização nos ângulos de 
$0,2^{\circ}$ (ângulo de observação) e $-4^{0}$ (ângulo de entrada). Foram realizadas avaliações de retrorrefletividade conforme padronizado pela ABNT - NBR 15426.

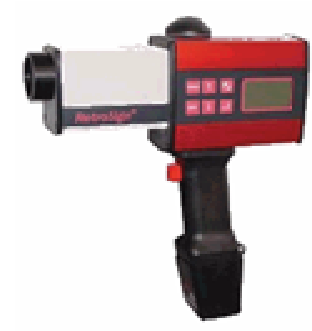

Figura 5.5 - Foto do equipamento de medição da retrorrefletividade. Fonte: Imagem editada pelo autor.

- Iluminação

Fontes luminosas com direcionamento exato simularam as situações de iluminação: diurno (ambiente todo iluminado), noturno (ambiente todo escuro e uma fonte de luz simulando o farol de um veículo) e noturno com iluminação superior a placa (ambiente escurecido com uma fonte de luz simulando o farol de um veículo e uma luz sobre a placa).

\subsection{DESCRIÇÃO DOS EXPERIMENTOS}

Seguindo o Método de Comparação aos Pares, os estímulos foram combinados dois a dois de forma que um estímulo não aparecesse em seqüência na mesma posição. Procurou-se também evitar que um mesmo estímulo aparecesse duas vezes consecutivas.

O sujeito se acomodava em uma das 15 cadeiras disponíveis na sala, preenchia o cabeçalho do questionário, conforme ANEXO 1, e lhe era dada a seguinte explicação sobre o experimento: "Serão apresentados a vocês dois tipos de sinais verticais de trânsito, sendo o primeiro sinal de regulamentação e o segundo sinal de indicação de localidade. Para os sinais de regulamentação existem 10 combinações dispostas aos pares em 3 situações diferentes (diurno, noturno e noturno com iluminação superior) e você terá que assinalar na tabela do 
questionário qual tem maior conspicuidade (impacto visual) e qual tem melhor legibilidade (facilidade de leitura). Para os sinais de indicação de localidade o procedimento é o mesmo, serão 10 combinações em 3 situações diferentes (diurno, noturno e noturno com iluminação superior). Assim que todos tiverem terminado de assinalar suas opções será exibida uma combinação diferente ou uma situação diferente".

\section{Experimento 1 - Avaliação da Conspicuidade e Legibilidade das Placas de Regulamentação}

Neste experimento as placas foram comparadas duas a duas. As variáveis eram os tipos de materiais utilizados na frente das placas $(1,2,3,4$ e 5); e as condições ambientes (diurno, noturno e noturno com iluminação sobre a placa).

- Participantes

Foram entrevistados 33 sujeitos, com idade variando de 26 a 65 anos, do sexo masculino e feminino, todos motoristas habilitados.

- Material

Foi utilizado o questionário apresentado no ANEXO 1, contendo as instruções específicas sobre o método utilizado e o formulário a ser respondido com caneta.

- Procedimento

As placas foram dispostas lado a lado em uma mesa de apoio de cor preta, sendo refletidas por meio de espelhos no fundo da sala.

Os sujeitos permaneciam sentados a uma distância de pelo menos 10 metros das imagens das placas. 
Realizada a análise, o sujeito anotava qual das duas placas apresentava maior conspicuidade e qual tinha melhor legibilidade. Foram apresentadas 10 combinações de placas em 3 situações de condições ambientais diferentes (diurno, noturno, noturno com iluminação sobre a placa). Cada combinação de placa apresentada (par) era constituída de materiais diferentes e era submetida à análise nas 3 condições ambientais distintas.

\section{Experimento 2 - Avaliação da Conspicuidade e Legibilidade das Placas de Indicação de Localidade}

Neste experimento as placas foram comparadas duas a duas. As variáveis eram os tipos de materiais utilizados na frente das placas $(1,2,3,4$ e 5); e as condições ambientes (diurno, noturno, noturno com iluminação sobre a placa).

- Participantes

Foram entrevistados 33 sujeitos, com idade variando de 26 a 65 anos, do sexo masculino e feminino, todos motoristas habilitados.

- Material

Foi utilizado o questionário apresentado no ANEXO 2, contendo as instruções específicas sobre o método utilizado e o formulário a ser respondido com caneta.

- Procedimento

As placas foram dispostas lado a lado em uma mesa de apoio de cor preta, sendo refletidas por meio de espelhos no fundo da sala. 
Os sujeitos permaneciam sentados a uma distância de pelo menos 10 metros das imagens das placas.

Realizada a análise, o sujeito anotava qual das duas placas apresentava maior conspicuidade e qual tinha melhor legibilidade. Foram apresentadas 10 combinações de placas em 3 situações de condições ambientais diferentes (diurno, noturno, noturno com iluminação sobre a placa). Cada combinação de placa apresentada (par) era constituída de materiais diferentes e era submetida à análise nas 3 condições ambientais distintas.

\section{Experimento 3 - Medida da Retrorrefletividade das Placas de Regulamentação e Indicativa de Localidade}

Todas as placas de regulamentação e indicativa de localidade utilizadas nos experimentos 1 e 2 foram submetidas a avaliação da retrorrefletividade.

- Material

Foram utilizadas as placas de regulamentação e de indicação descritas anteriormente e um retrorrefletômetro portátil.

- Procedimento

$\mathrm{Na}$ realização deste experimento foram seguidas as diretrizes da ABNT NBR 15.426 (Sinalização vertical viária - Avaliação da retrorrefletividade utilizando retrorrefletômetro portátil). Utilizando-se um aparelho retrorrefletômetro portátil (Delta Retrosign 4000) foram tomadas 5 medidas de retrorrefletividade de cada cor de material contido na placa de sinalização e realizada uma média. $\mathrm{O}$ valor desta média é comparado com o valor mínimo residual para o tipo de película refletiva, conforme NBR 14644. Estando este valor acima do mínimo residual a película retrorrefletiva está aprovada. 


\section{6 \\ APRESENTAÇÃO E ANÁLISE DOS RESULTADOS OBTIDOS}

\subsection{AVALIAÇÃO DA CONSPICUIDADE E LEGIBILIDADE DA PLACA DE REGULAMENTAÇÃO (EXPERIMENTO 1)}

\subsubsection{AVALIAÇÃO DA CONSPICUIDADE}

- AMBIENTE ILUMINADO SEM INCIDÊNCIA DE FEIXE DE LUZ SOBRE AS PLACAS (SIMULAÇÃO DO PERÍODO DIURNO)

Neste caso, todas as placas são visíveis e percebidas como placas de sinalização de trânsito, isto é, apresentam conspicuidade satisfatória.

Os resultados obtidos nos experimentos encontram-se nas Tabelas 6.1 a 6.3.

Tabela 6.1 - Matriz de indicações para o período diurno

\begin{tabular}{|c|c|c|c|c|c|}
\hline TIPO & $\mathbf{1}$ & $\mathbf{2}$ & $\mathbf{3}$ & $\mathbf{4}$ & $\mathbf{5}$ \\
\hline $\mathbf{1}$ & - & 27 & 33 & 32 & 33 \\
\hline $\mathbf{2}$ & 6 & - & 26 & 33 & 33 \\
\hline $\mathbf{3}$ & 0 & 7 & - & 30 & 10 \\
\hline $\mathbf{4}$ & 1 & 0 & 3 & - & 21 \\
\hline $\mathbf{5}$ & 0 & 0 & 23 & 12 & - \\
\hline
\end{tabular}

Tabela 6.2 - Proporções médias de indicações para o período diurno

\begin{tabular}{|c|c|c|c|c|c|}
\hline TIPO & $\mathbf{1}$ & $\mathbf{2}$ & $\mathbf{3}$ & $\mathbf{4}$ & $\mathbf{5}$ \\
\hline $\mathbf{1}$ & $50 \%$ & $82 \%$ & $100 \%$ & $97 \%$ & $100 \%$ \\
\hline $\mathbf{2}$ & $18 \%$ & $50 \%$ & $79 \%$ & $100 \%$ & $100 \%$ \\
\hline $\mathbf{3}$ & $0 \%$ & $21 \%$ & $50 \%$ & $91 \%$ & $30 \%$ \\
\hline $\mathbf{4}$ & $3 \%$ & $0 \%$ & $9 \%$ & $50 \%$ & $64 \%$ \\
\hline $\mathbf{5}$ & $0 \%$ & $0 \%$ & $70 \%$ & $36 \%$ & $50 \%$ \\
\hline
\end{tabular}


Tabela 6.3 - Escores z médios derivados da matriz de proporções médias para o período diurno

\begin{tabular}{|c|c|c|c|c|c|c|c|c|}
\hline TIPO & $\mathbf{1}$ & $\mathbf{2}$ & $\mathbf{3}$ & $\mathbf{4}$ & $\mathbf{5}$ & Média & Escala Ajustada & ORDEM \\
\hline $\mathbf{1}$ & 0 & 0,91 & 3,30 & 1,88 & 3,30 & 1,88 & 3,17 & $\mathbf{1}^{\mathbf{0}}$ \\
\hline $\mathbf{2}$ & $-0,91$ & 0 & 0,80 & 3,30 & 3,30 & 1,30 & 2,59 & $\mathbf{2}^{\mathbf{0}}$ \\
\hline $\mathbf{3}$ & $-3,30$ & $-0,80$ & 0 & 1,34 & $-0,52$ & $-0,66$ & 0,63 & $\mathbf{3}^{\mathbf{0}}$ \\
\hline $\mathbf{4}$ & $-1,88$ & $-3,30$ & $-1,34$ & 0 & 0,35 & $-1,23$ & 0,06 & $\mathbf{4}^{\mathbf{0}}$ \\
\hline $\mathbf{5}$ & $-3,30$ & $-3,30$ & 0,52 & $-0,35$ & 0 & $-1,29$ & 0,00 & $\mathbf{5}^{\mathbf{0}}$ \\
\hline
\end{tabular}

Conforme indicam os valores da Tabela 6.3, a ordem de preferência dos entrevistados é a seguinte: placas 1, 2, 3, 4 e 5. A explicação é que os materiais retrorrefletivos do fundo e/ou dos caracteres possuem na sua constituição elementos (microesferas de vidro ou prismas) para fazer a retrorreflexão da luz incidente, o que torna a visualização da cor, especialmente a cor branca, mais opaca durante o período diurno. Com isso diminui o contraste entre as cores, piorando a conspicuidade.

\section{- AMBIENTE ESCURO COM INCIDÊNCIA DE FEIXE DE LUZ SOBRE AS PLACAS (SIMULAÇÃO DO PERÍODO NOTURNO EM VIAS NÃO ILUMINADAS)}

Neste caso, somente as placas 3, 4 e 5 (que contêm material refletivo no fundo e nos caracteres) são visíveis e percebidas como placas de sinalização de trânsito, isto é, apresentam conspicuidade satisfatória. A visão da placa 1 (que não contém material refletivo) sob a incidência do feixe de luz, simulando o farol de um veículo, é um vulto negro de forma circular, apresentando, portanto, conspicuidade completamente insatisfatória. Na placa 2, a visão é de um vulto negro (fundo de material não refletivo) contido numa faixa circular brilhante (orla de material refletivo) e com letras brilhantes no interior (letras de material refletivo).

Os resultados obtidos nos experimentos encontram-se nas Tabelas 6.4 a 6.6. 
Tabela 6.4 - Matriz de indicações para o período noturno

\begin{tabular}{|c|c|c|c|c|c|}
\hline TIPO & $\mathbf{1}$ & $\mathbf{2}$ & $\mathbf{3}$ & $\mathbf{4}$ & $\mathbf{5}$ \\
\hline $\mathbf{1}$ & - & 0 & 0 & 0 & 0 \\
\hline $\mathbf{2}$ & 33 & - & 7 & 4 & 0 \\
\hline $\mathbf{3}$ & 33 & 26 & - & 15 & 0 \\
\hline $\mathbf{4}$ & 33 & 29 & 18 & - & 0 \\
\hline $\mathbf{5}$ & 33 & 33 & 33 & 33 & - \\
\hline
\end{tabular}

Tabela 6.5 - Proporções médias de indicações para o período noturno

\begin{tabular}{|c|c|c|c|c|c|}
\hline TIPO & $\mathbf{1}$ & $\mathbf{2}$ & $\mathbf{3}$ & $\mathbf{4}$ & $\mathbf{5}$ \\
\hline $\mathbf{1}$ & $50 \%$ & $0 \%$ & $0 \%$ & $0 \%$ & $0 \%$ \\
\hline $\mathbf{2}$ & $100 \%$ & $50 \%$ & $21 \%$ & $12 \%$ & $0 \%$ \\
\hline $\mathbf{3}$ & $100 \%$ & $79 \%$ & $50 \%$ & $46 \%$ & $0 \%$ \\
\hline $\mathbf{4}$ & $100 \%$ & $88 \%$ & $54 \%$ & $50 \%$ & $0 \%$ \\
\hline $\mathbf{5}$ & $100 \%$ & $100 \%$ & $100 \%$ & $100 \%$ & $50 \%$ \\
\hline
\end{tabular}

Tabela 6.6 - Escores z médios derivados da matriz de proporções médias para o período noturno

\begin{tabular}{|c|c|c|c|c|c|c|c|c|}
\hline TIPO & $\mathbf{1}$ & $\mathbf{2}$ & $\mathbf{3}$ & $\mathbf{4}$ & $\mathbf{5}$ & Média & Escala Ajustada & ORDEM \\
\hline $\mathbf{1}$ & 0 & $-3,30$ & $-3,30$ & $-3,30$ & $-3,30$ & $-3,30$ & 0 & $\mathbf{5}^{\mathbf{0}}$ \\
\hline $\mathbf{2}$ & 3,30 & 0 & $-0,80$ & $-1,17$ & $-3,30$ & $-0,39$ & 2,91 & $\mathbf{4}^{\mathbf{0}}$ \\
\hline $\mathbf{3}$ & 3,30 & 0,80 & 0 & $-0,11$ & $-3,30$ & 0,14 & 3,44 & $\mathbf{3}^{\mathbf{0}}$ \\
\hline $\mathbf{4}$ & 3,30 & 1,17 & 0,11 & 0 & $-3,30$ & 0,26 & 3,56 & $\mathbf{2}^{\mathbf{0}}$ \\
\hline $\mathbf{5}$ & 3,30 & 3,30 & 3,30 & 3,30 & 0 & 3,30 & 6,60 & $\mathbf{1}^{\mathbf{o}}$ \\
\hline
\end{tabular}

Conforme indicam os valores da Tabela 6.6, a ordem de preferência dos entrevistados é a seguinte: placas 5, 4, 3, 2 e 1. A explicação é que o material retrorrefletivo faz com que o fundo e/ou os caracteres da placa brilhem com a incidência do feixe de luz, simulando o farol de um veículo, proporcionando maior contraste em relação ao meio ambiente escuro e, assim, melhorando a conspicuidade da placa. Quanto mais eficiente o material retrorrefletivo, mais intenso o brilho e, por consequiência, melhor o contraste deste com o meio no qual esta inserido e melhor a conspicuidade. 
- AMBIENTE ESCURO COM ILUMINAÇÃO SUPERIOR E INCIDÊNCIA DE FEIXE DE LUZ SOBRE AS PLACAS (SIMULAÇÃO DE VIAS ILUMINADAS NO PERÍODO NOTURNO E VIAS NÃO ILUMINADAS DURANTE O NASCER E O POR DO SOL)

Neste caso, todas as placas são visíveis e percebidas como placas de sinalização de trânsito, isto é, apresentam satisfatória conspicuidade.

Os resultados obtidos nos experimentos encontram-se nas Tabelas 6.7 a 6.9.

Tabela 6.7 - Matriz de indicações para o período noturno com iluminação

\begin{tabular}{|c|c|c|c|c|c|}
\hline TIPO & $\mathbf{1}$ & $\mathbf{2}$ & $\mathbf{3}$ & $\mathbf{4}$ & $\mathbf{5}$ \\
\hline $\mathbf{1}$ & - & 3 & 0 & 2 & 0 \\
\hline $\mathbf{2}$ & 30 & - & 5 & 2 & 0 \\
\hline $\mathbf{3}$ & 33 & 28 & - & 13 & 0 \\
\hline $\mathbf{4}$ & 31 & 31 & 20 & - & 1 \\
\hline $\mathbf{5}$ & 33 & 33 & 33 & 32 & - \\
\hline
\end{tabular}

Tabela 6.8 - Proporções médias de indicações para o período noturno com iluminação

\begin{tabular}{|c|c|c|c|c|c|}
\hline TIPO & $\mathbf{1}$ & $\mathbf{2}$ & $\mathbf{3}$ & $\mathbf{4}$ & $\mathbf{5}$ \\
\hline $\mathbf{1}$ & $50 \%$ & $9 \%$ & $0 \%$ & $6 \%$ & $0 \%$ \\
\hline $\mathbf{2}$ & $91 \%$ & $50 \%$ & $15 \%$ & $6 \%$ & $0 \%$ \\
\hline $\mathbf{3}$ & $100 \%$ & $85 \%$ & $50 \%$ & $39 \%$ & $0 \%$ \\
\hline $\mathbf{4}$ & $94 \%$ & $94 \%$ & $61 \%$ & $50 \%$ & $3 \%$ \\
\hline $\mathbf{5}$ & $100 \%$ & $100 \%$ & $100 \%$ & $97 \%$ & $50 \%$ \\
\hline
\end{tabular}

Tabela 6.9 - Escores z médios derivados da matriz de proporções médias para o período noturno com iluminação

\begin{tabular}{|c|c|c|c|c|c|c|c|c|}
\hline TIPO & $\mathbf{1}$ & $\mathbf{2}$ & $\mathbf{3}$ & $\mathbf{4}$ & $\mathbf{5}$ & Média & Escala Ajustada & ORDEM \\
\hline $\mathbf{1}$ & 0 & $-1,34$ & $-3,30$ & $-1,55$ & $-3,30$ & $-1,90$ & 0 & $\mathbf{5}^{\mathbf{0}}$ \\
\hline $\mathbf{2}$ & 1,34 & 0 & $-1,03$ & $-1,55$ & $-3,30$ & $-0,91$ & 0,99 & $\mathbf{4}^{\mathbf{0}}$ \\
\hline $\mathbf{3}$ & 3,30 & 1,03 & 0 & $-0,27$ & $-3,30$ & 0,15 & 2,05 & $\mathbf{3}^{\mathbf{0}}$ \\
\hline $\mathbf{4}$ & 1,55 & 1,55 & 0,27 & 0 & $-1,88$ & 0,30 & 2,20 & $\mathbf{2}^{\mathbf{0}}$ \\
\hline $\mathbf{5}$ & 3,30 & 3,30 & 3,30 & 1,88 & 0 & 2,36 & 4,26 & $\mathbf{1}^{\mathbf{0}}$ \\
\hline
\end{tabular}

Conforme indicam os valores da Tabela 6.9, a ordem de preferência dos entrevistados é a seguinte: placas 5, 4, 3, 2 e 1 . A explicação é que o material retrorrefletivo faz com que o fundo e/ou os caracteres da placa brilhem com a 
incidência do feixe de luz, simulando o farol de um veículo, proporcionando maior contraste em relação ao meio ambiente parcialmente escuro e, assim, melhorando a conspicuidade da placa; quanto mais eficiente o material retrorrefletivo, mais intenso o brilho e, por conseqüência, melhor o contraste deste com o meio no qual esta inserido e melhor a conspicuidade.

\subsubsection{AVALIAÇÃO DA LEGIBILIDADE}

\section{- AMBIENTE ILUMINADO SEM INCIDÊNCIA DE FEIXE DE LUZ SOBRE AS PLACAS (SIMULAÇÃO DO PERÍODO DIURNO)}

Neste caso, os caracteres de todas as placas são legíveis e, portanto, apresentam legibilidade satisfatória.

Os resultados obtidos no experimento encontram-se nas Tabelas 6.10 a 6.12 .

Tabela 6.10 - Matriz de indicações para o período diurno

\begin{tabular}{|c|c|c|c|c|c|}
\hline TIPO & $\mathbf{1}$ & $\mathbf{2}$ & $\mathbf{3}$ & $\mathbf{4}$ & $\mathbf{5}$ \\
\hline $\mathbf{1}$ & - & 28 & 29 & 33 & 33 \\
\hline $\mathbf{2}$ & 5 & - & 27 & 31 & 28 \\
\hline $\mathbf{3}$ & 4 & 6 & - & 25 & 13 \\
\hline $\mathbf{4}$ & 0 & 2 & 8 & - & 18 \\
\hline $\mathbf{5}$ & 0 & 5 & 20 & 15 & - \\
\hline
\end{tabular}

Tabela 6.11 - Proporções médias de indicações para o período diurno

\begin{tabular}{|c|c|c|c|c|c|}
\hline TIPO & $\mathbf{1}$ & $\mathbf{2}$ & $\mathbf{3}$ & $\mathbf{4}$ & $\mathbf{5}$ \\
\hline $\mathbf{1}$ & $50 \%$ & $85 \%$ & $88 \%$ & $100 \%$ & $100 \%$ \\
\hline $\mathbf{2}$ & $15 \%$ & $50 \%$ & $82 \%$ & $94 \%$ & $85 \%$ \\
\hline $\mathbf{3}$ & $12 \%$ & $18 \%$ & $50 \%$ & $76 \%$ & $39 \%$ \\
\hline $\mathbf{4}$ & $0 \%$ & $6 \%$ & $24 \%$ & $50 \%$ & $54 \%$ \\
\hline $\mathbf{5}$ & $0 \%$ & $15 \%$ & $61 \%$ & $56 \%$ & $50 \%$ \\
\hline
\end{tabular}


Tabela 6.12 - Escores z médios derivados da matriz de proporções médias para o período diurno

\begin{tabular}{|c|c|c|c|c|c|c|c|c|}
\hline TIPO & $\mathbf{1}$ & $\mathbf{2}$ & $\mathbf{3}$ & $\mathbf{4}$ & $\mathbf{5}$ & Média & Escala Ajustada & ORDEM \\
\hline $\mathbf{1}$ & 0 & 1,03 & 1,17 & 3,30 & 3,30 & 1,76 & 2,85 & $\mathbf{1}^{\mathbf{0}}$ \\
\hline $\mathbf{2}$ & $-1,03$ & 0 & 0,91 & 1,55 & 1,03 & 0,49 & 1,58 & $\mathbf{2}^{\mathbf{0}}$ \\
\hline $\mathbf{3}$ & $-1,17$ & $-0,91$ & 0 & 0,70 & $-0,27$ & $-0,33$ & 0,76 & $\mathbf{3}^{\mathbf{0}}$ \\
\hline $\mathbf{4}$ & $-3,30$ & $-1,55$ & $-0,70$ & 0 & 0,11 & $-1,09$ & 0,00 & $\mathbf{5}^{\mathbf{0}}$ \\
\hline $\mathbf{5}$ & $-3,30$ & $-1,03$ & 0,27 & $-0,11$ & 0 & $-0,83$ & 0,26 & $\mathbf{4}^{\mathbf{0}}$ \\
\hline
\end{tabular}

Conforme indicam os valores da Tabela 6.12, a ordem de preferência dos entrevistados é a seguinte: 1, 2, 3, 5 e 4. A explicação é que os materiais retrorrefletivos do fundo e/ou dos caracteres possuem na sua constituição elementos (microesferas de vidro ou prismas) para fazer a retrorreflexão da luz incidente, o que torna a visualização da cor, especialmente a cor branca, mais opaca durante o período diurno. Com isso diminui o contraste entre as cores, piorando a legibilidade. Não se encontrou explicação para a ordem invertida das placas 4 e 5 .

\section{- AMBIENTE ESCURO COM INCIDÊNCIA DE FEIXE DE LUZ SOBRE AS PLACAS (SIMULAÇÃO DO PERÍODO NOTURNO EM VIAS NÃO ILUMINADAS)}

Neste caso, somente as placas 2, 3, 4 e 5 são legíveis com a incidência direta do feixe de luz, isto é, apresentam legibilidade satisfatória. A visão da placa 1 (que não contém material refletivo) é um vulto negro de forma circular, sem possibilidade de identificação dos caracteres e, portanto, sem legibilidade.

Os resultados obtidos nos experimentos encontram-se nas Tabelas 6.13 a 6.15 .

Tabela 6.13 - Matriz de indicações para o período noturno

\begin{tabular}{|c|c|c|c|c|c|}
\hline TIPO & $\mathbf{1}$ & $\mathbf{2}$ & $\mathbf{3}$ & $\mathbf{4}$ & $\mathbf{5}$ \\
\hline $\mathbf{1}$ & - & 2 & 0 & 0 & 0 \\
\hline $\mathbf{2}$ & 31 & - & 1 & 3 & 2 \\
\hline $\mathbf{3}$ & 33 & 32 & - & 4 & 7 \\
\hline $\mathbf{4}$ & 33 & 30 & 29 & - & 7 \\
\hline $\mathbf{5}$ & 33 & 31 & 26 & 26 & - \\
\hline
\end{tabular}


Tabela 6.14 - Proporções médias de indicações para o período noturno

\begin{tabular}{|c|c|c|c|c|c|}
\hline TIPO & $\mathbf{1}$ & $\mathbf{2}$ & $\mathbf{3}$ & $\mathbf{4}$ & $\mathbf{5}$ \\
\hline $\mathbf{1}$ & $50 \%$ & $6 \%$ & $0 \%$ & $0 \%$ & $0 \%$ \\
\hline $\mathbf{2}$ & $94 \%$ & $50 \%$ & $3 \%$ & $9 \%$ & $6 \%$ \\
\hline $\mathbf{3}$ & $100 \%$ & $97 \%$ & $50 \%$ & $12 \%$ & $21 \%$ \\
\hline $\mathbf{4}$ & $100 \%$ & $91 \%$ & $88 \%$ & $50 \%$ & $21 \%$ \\
\hline $\mathbf{5}$ & $100 \%$ & $94 \%$ & $79 \%$ & $79 \%$ & $50 \%$ \\
\hline
\end{tabular}

Tabela 6.15 - Escores z médios derivados da matriz de proporções médias para o período noturno

\begin{tabular}{|c|c|c|c|c|c|c|c|c|}
\hline TIPO & $\mathbf{1}$ & $\mathbf{2}$ & $\mathbf{3}$ & $\mathbf{4}$ & $\mathbf{5}$ & Média & Escala Ajustada & ORDEM \\
\hline $\mathbf{1}$ & 0 & $-1,55$ & $-3,30$ & $-3,30$ & $-3,30$ & $-2,29$ & 0,00 & $\mathbf{5}^{\mathbf{0}}$ \\
\hline $\mathbf{2}$ & 1,55 & 0 & $-1,88$ & $-1,34$ & $-1,55$ & $-0,64$ & 1,65 & $\mathbf{4}^{\mathbf{0}}$ \\
\hline $\mathbf{3}$ & 3,30 & 1,88 & 0 & $-1,17$ & $-0,80$ & 0,64 & 2,93 & $\mathbf{3}^{\mathbf{0}}$ \\
\hline $\mathbf{4}$ & 3,30 & 1,34 & 1,17 & 0 & $-0,80$ & 1,00 & 3,29 & $\mathbf{2}^{\mathbf{0}}$ \\
\hline $\mathbf{5}$ & 3,30 & 1,55 & 0,80 & 0,80 & 0 & 1,29 & 3,58 & $\mathbf{1}^{\mathbf{o}}$ \\
\hline
\end{tabular}

Conforme indicam os valores da Tabela 6.15, a ordem de preferência dos entrevistados é a seguinte: 5, 4, 3, 2 e 1 . A explicação é que o material não refletivo das letras proporciona contraste com o fundo brilhante confeccionado com material refletivo (caso das placas 3, 4 e 5). No caso da placa 2, as letras é que são refletivas e o fundo não. Quanto maior a retrorrefletividade da película do fundo, maiores o contraste e a legibilidade, pois o material das letras não é refletivo. Como nas placas 2 e 3 são empregados materiais similares nas letras e fundos, mas invertidos, o resultado mostra que é melhor empregar letras não refletivas e fundo refletivo (caso da placa 3) e não o contrário (caso da placa 2).

- AMBIENTE ESCURO COM ILUMINAÇÃO SUPERIOR E INCIDÊNCIA DE FEIXE DE LUZ SOBRE AS PLACAS (SIMULAÇÃO DE VIAS ILUMINADAS NO PERÍODO NOTURNO E VIAS NÃO ILUMINADAS DURANTE O NASCER E O POR DO SOL)

No experimento foi constatado que num ambiente com pouca iluminação, os caracteres das placas 1 e 2 não são legíveis sob a incidência do feixe de luz simulando o farol de um veículo. Para o caso da placa 1, a explicação é que não possuindo material retrorrefletivo, o fundo e os caracteres ficam sem brilho, ficando 
os caracteres ilegíveis. No caso da placa de tipo 2, as letras de cor preta de material refletivo brilham e ficam de cor branca sob a incidência da luz dos faróis, não havendo, portanto, contraste em relação ao fundo branco da placa. Desta maneira a placa é visualizada com uma orla vermelha e interior branco, sem caracteres.

Os resultados obtidos nos experimentos encontram-se nas Tabelas 6.16 a 6.18 .

Tabela 6.16 - Matriz de indicações para o período noturno com iluminação

\begin{tabular}{|c|c|c|c|c|c|}
\hline TIPO & $\mathbf{1}$ & $\mathbf{2}$ & $\mathbf{3}$ & $\mathbf{4}$ & $\mathbf{5}$ \\
\hline $\mathbf{1}$ & - & 15 & 4 & 3 & 0 \\
\hline $\mathbf{2}$ & 18 & - & 1 & 0 & 0 \\
\hline $\mathbf{3}$ & 29 & 32 & - & 2 & 6 \\
\hline $\mathbf{4}$ & 30 & 33 & 31 & - & 9 \\
\hline $\mathbf{5}$ & 33 & 33 & 27 & 24 & - \\
\hline
\end{tabular}

Tabela 6.17 - Proporções médias de indicações para o período noturno com iluminação

\begin{tabular}{|c|c|c|c|c|c|}
\hline TIPO & $\mathbf{1}$ & $\mathbf{2}$ & $\mathbf{3}$ & $\mathbf{4}$ & $\mathbf{5}$ \\
\hline $\mathbf{1}$ & $50 \%$ & $45 \%$ & $12 \%$ & $9 \%$ & $0 \%$ \\
\hline $\mathbf{2}$ & $55 \%$ & $50 \%$ & $3 \%$ & $0 \%$ & $0 \%$ \\
\hline $\mathbf{3}$ & $88 \%$ & $97 \%$ & $50 \%$ & $6 \%$ & $18 \%$ \\
\hline $\mathbf{4}$ & $91 \%$ & $100 \%$ & $94 \%$ & $50 \%$ & $27 \%$ \\
\hline $\mathbf{5}$ & $100 \%$ & $100 \%$ & $82 \%$ & $73 \%$ & $50 \%$ \\
\hline
\end{tabular}

Tabela 6.18 - Escores z médios derivados da matriz de proporções médias para o período noturno com iluminação

\begin{tabular}{|c|c|c|c|c|c|c|c|c|}
\hline TIPO & $\mathbf{1}$ & $\mathbf{2}$ & $\mathbf{3}$ & $\mathbf{4}$ & $\mathbf{5}$ & Média & Escala Ajustada & ORDEM \\
\hline $\mathbf{1}$ & 0 & $-0,11$ & $-1,17$ & $-1,34$ & $-3,30$ & $-1,18$ & 0,49 & $\mathbf{4}^{\mathbf{0}}$ \\
\hline $\mathbf{2}$ & 0,11 & 0 & $-1,88$ & $-3,30$ & $-3,30$ & $-1,67$ & 0,00 & $\mathbf{5}^{\mathbf{0}}$ \\
\hline $\mathbf{3}$ & 1,17 & 1,88 & 0 & $-1,55$ & $-0,91$ & 0,12 & 1,79 & $\mathbf{3}^{\mathbf{0}}$ \\
\hline $\mathbf{4}$ & 1,34 & 3,30 & 1,55 & 0 & $-0,60$ & 1,12 & 2,79 & $\mathbf{2}^{\mathbf{0}}$ \\
\hline $\mathbf{5}$ & 3,30 & 3,30 & 0,91 & 0,60 & 0 & 1,62 & 3,29 & $\mathbf{1}^{\mathbf{0}}$ \\
\hline
\end{tabular}

Conforme indicam os valores da Tabela 6.18 , a ordem de preferência dos entrevistados no tocante à legibilidade é a seguinte: 5,4 e 3 (as placas do tipo 1 e 2 não devem ser consideradas por não terem os caracteres legíveis). A explicação é que o material retrorrefletivo do fundo e da tarja brilha com a incidência do feixe de luz simulando o farol do veículo, proporcionando contraste com as letras não 
refletivas. Quanto maior a eficiência do material retrorrefletivo, maiores o contraste e a legibilidade.

\subsection{AVALIAÇÃO DA CONSPICUIDADE E LEGIBILIDADE DA PLACA DE INDICAÇÃO DE LOCALIDADE (EXPERIMENTO 2)}

\subsubsection{AVALIAÇÃO DA CONSPICUIDADE}

\section{- AMBIENTE ILUMINADO SEM INCIDÊNCIA DE FEIXE DE LUZ SOBRE AS PLACAS (SIMULAÇÃO DO PERÍODO DIURNO)}

Neste caso, todas as placas são visíveis e percebidas como placas de sinalização de trânsito, isto é, apresentam satisfatória conspicuidade.

Os resultados obtidos nos experimentos encontram-se nas Tabelas 6.19 a 6.21 .

Tabela 6.19 - Matriz de indicações para o período diurno

\begin{tabular}{|c|c|c|c|c|c|}
\hline TIPO & $\mathbf{1}$ & $\mathbf{2}$ & $\mathbf{3}$ & $\mathbf{4}$ & $\mathbf{5}$ \\
\hline $\mathbf{1}$ & - & 27 & 25 & 29 & 15 \\
\hline $\mathbf{2}$ & 6 & - & 17 & 26 & 18 \\
\hline $\mathbf{3}$ & 8 & 16 & - & 30 & 22 \\
\hline $\mathbf{4}$ & 4 & 7 & 3 & - & 20 \\
\hline $\mathbf{5}$ & 18 & 15 & 11 & 13 & - \\
\hline
\end{tabular}

Tabela 6.20 - Proporções médias de indicações para o período diurno

\begin{tabular}{|c|c|c|c|c|c|}
\hline TIPO & $\mathbf{1}$ & $\mathbf{2}$ & $\mathbf{3}$ & $\mathbf{4}$ & $\mathbf{5}$ \\
\hline $\mathbf{1}$ & $50 \%$ & $82 \%$ & $76 \%$ & $88 \%$ & $45 \%$ \\
\hline $\mathbf{2}$ & $18 \%$ & $50 \%$ & $51 \%$ & $79 \%$ & $54 \%$ \\
\hline $\mathbf{3}$ & $24 \%$ & $49 \%$ & $50 \%$ & $91 \%$ & $67 \%$ \\
\hline $\mathbf{4}$ & $12 \%$ & $21 \%$ & $9 \%$ & $50 \%$ & $61 \%$ \\
\hline $\mathbf{5}$ & $55 \%$ & $46 \%$ & $33 \%$ & $39 \%$ & $50 \%$ \\
\hline
\end{tabular}


Tabela 6.21 - Escores z médios derivados da matriz de proporções médias para o período diurno

\begin{tabular}{|c|c|c|c|c|c|c|c|c|}
\hline TIPO & $\mathbf{1}$ & $\mathbf{2}$ & $\mathbf{3}$ & $\mathbf{4}$ & $\mathbf{5}$ & Média & Escala Ajustada & ORDEM \\
\hline $\mathbf{1}$ & 0 & 0,91 & 0,70 & 1,17 & $-0,11$ & 0,53 & 1,14 & $\mathbf{1}^{\mathbf{0}}$ \\
\hline $\mathbf{2}$ & $-0,91$ & 0 & 0,04 & 0,80 & 0,11 & 0,01 & 0,62 & $\mathbf{3}^{\mathbf{0}}$ \\
\hline $\mathbf{3}$ & $-0,70$ & $-0,04$ & 0 & 1,34 & 0,43 & 0,21 & 0,82 & $\mathbf{2}^{\mathbf{0}}$ \\
\hline $\mathbf{4}$ & $-1,17$ & $-0,80$ & $-1,34$ & 0 & 0,27 & $-0,61$ & 0,00 & $\mathbf{5}^{\mathbf{0}}$ \\
\hline $\mathbf{5}$ & 0,11 & $-0,11$ & $-0,43$ & $-0,27$ & 0 & $-0,14$ & 0,47 & $\mathbf{4}^{\mathbf{0}}$ \\
\hline
\end{tabular}

Conforme indicam os valores da Tabela 6.21, a ordem de preferência dos entrevistados é a seguinte: placas 1, 3, 2, 5 e 4. A explicação é que os materiais retrorrefletivos do fundo e/ou dos caracteres possuem na sua constituição elementos (microesferas de vidro ou prismas) para fazer a retrorreflexão da luz incidente, o que torna a visualização da cor, especialmente a cor branca, mais opaca durante o período diurno. Com isso diminui o contraste entre as cores, piorando a conspicuidade. Não se tem explicação para a ordem invertida das placas 2 e 3, bem como 4 e 5 .

- AMBIENTE ESCURO COM INCIDÊNCIA DE FEIXE DE LUZ SObRe AS PLACAS (SIMULAÇÃo DO PERÍOdo NOTURNO EM VIAS NÃO ILUMINADAS)

Neste caso, somente as placas 3, 4 e 5 (que contêm material refletivo no fundo e nos caracteres) são visíveis e percebidas como placas de sinalização de trânsito, isto é, apresentam satisfatória conspicuidade. A visão da placa 1 (que não contém material refletivo) sob a incidência do feixe de luz, simulando o farol de um veículo, é de um vulto negro de forma retangular, apresentando, portanto, conspicuidade completamente insatisfatória. Na placa 2, a visão é de um vulto negro (fundo de material não refletivo) contido numa faixa retangular brilhante (orla de material refletivo) e com letras brilhantes no interior (letras de material refletivo), o que caracteriza uma situação de conspicuidade insatisfatória.

Os resultados obtidos nos experimentos encontram-se nas Tabelas 6.22 a 6.24 . 
Tabela 6.22 - Matriz de indicações para o período noturno

\begin{tabular}{|c|c|c|c|c|c|}
\hline TIPO & $\mathbf{1}$ & $\mathbf{2}$ & $\mathbf{3}$ & $\mathbf{4}$ & $\mathbf{5}$ \\
\hline $\mathbf{1}$ & - & 0 & 0 & 0 & 0 \\
\hline $\mathbf{2}$ & 33 & - & 10 & 4 & 0 \\
\hline $\mathbf{3}$ & 33 & 23 & - & 3 & 0 \\
\hline $\mathbf{4}$ & 33 & 29 & 30 & - & 0 \\
\hline $\mathbf{5}$ & 33 & 33 & 33 & 33 & - \\
\hline
\end{tabular}

Tabela 6.23 - Proporções médias de indicações para o período noturno (2c)

\begin{tabular}{|c|c|c|c|c|c|}
\hline TIPO & $\mathbf{1}$ & $\mathbf{2}$ & $\mathbf{3}$ & $\mathbf{4}$ & $\mathbf{5}$ \\
\hline $\mathbf{1}$ & $50 \%$ & $0 \%$ & $0 \%$ & $0 \%$ & $0 \%$ \\
\hline $\mathbf{2}$ & $100 \%$ & $50 \%$ & $30 \%$ & $12 \%$ & $0 \%$ \\
\hline $\mathbf{3}$ & $100 \%$ & $70 \%$ & $50 \%$ & $9 \%$ & $0 \%$ \\
\hline $\mathbf{4}$ & $100 \%$ & $88 \%$ & $91 \%$ & $50 \%$ & $0 \%$ \\
\hline $\mathbf{5}$ & $100 \%$ & $100 \%$ & $100 \%$ & $100 \%$ & $50 \%$ \\
\hline
\end{tabular}

Tabela 6.24 - Escores z médios derivados da matriz de proporções médias para o período noturno

\begin{tabular}{|c|c|c|c|c|c|c|c|c|}
\hline TIPO & $\mathbf{1}$ & $\mathbf{2}$ & $\mathbf{3}$ & $\mathbf{4}$ & $\mathbf{5}$ & Média & Escala Ajustada & ORDEM \\
\hline $\mathbf{1}$ & 0 & $-3,30$ & $-3,30$ & $-3,30$ & $-3,30$ & $-3,30$ & 0,00 & $\mathbf{5}^{\mathbf{0}}$ \\
\hline $\mathbf{2}$ & 3,30 & 0 & $-0,52$ & $-1,17$ & $-3,30$ & $-0,34$ & 2,96 & $\mathbf{4}^{\mathbf{0}}$ \\
\hline $\mathbf{3}$ & 3,30 & 0,52 & 0 & $-1,34$ & $-3,30$ & $-0,16$ & 3,14 & $\mathbf{3}^{\mathbf{0}}$ \\
\hline $\mathbf{4}$ & 3,30 & 1,17 & 1,34 & 0 & $-3,30$ & 0,50 & 3,80 & $\mathbf{2}^{\mathbf{0}}$ \\
\hline $\mathbf{5}$ & 3,30 & 3,30 & 3,30 & 3,30 & 0 & 3,30 & 6,60 & $\mathbf{1}^{\mathbf{0}}$ \\
\hline
\end{tabular}

Conforme indicam os valores da Tabela 6.24, a ordem de preferência dos entrevistados é a seguinte: placas 5, 4, 3, 2 e 1. A explicação é que o material retrorrefletivo faz com que o fundo e/ou os caracteres da placa brilhem com a incidência do feixe de luz, simulando o farol de um veículo, proporcionando maior contraste em relação ao meio ambiente escuro e, assim, melhorando a conspicuidade da placa. Quanto mais eficiente o material retrorrefletivo, mais intenso o brilho e, por consequiência, melhores são o contraste e a conspicuidade.

- AMBIENTE ESCURO COM ILUMINAÇÃO SUPERIOR E INCIDÊNCIA DE FEIXE DE LUZ SOBRE AS PLACAS (SIMULAÇÃO DE VIAS ILUMINADAS NO PERÍODO NOTURNO E VIAS NÃO ILUMINADAS DURANTE O NASCER E O POR DO SOL) 
Neste caso, todas as placas são visíveis e percebidas como placas de sinalização de trânsito, isto é, apresentam satisfatória conspicuidade.

Os resultados obtidos nos experimentos encontram-se nas Tabelas 6.25 a 6.27 .

Tabela 6.25 - Matriz de indicações para o período noturno com iluminação

\begin{tabular}{|c|c|c|c|c|c|}
\hline TIPO & $\mathbf{1}$ & $\mathbf{2}$ & $\mathbf{3}$ & $\mathbf{4}$ & $\mathbf{5}$ \\
\hline $\mathbf{1}$ & - & 0 & 1 & 0 & 0 \\
\hline $\mathbf{2}$ & 33 & - & 8 & 6 & 0 \\
\hline $\mathbf{3}$ & 32 & 25 & - & 0 & 0 \\
\hline $\mathbf{4}$ & 33 & 27 & 33 & - & 0 \\
\hline $\mathbf{5}$ & 33 & 33 & 33 & 33 & - \\
\hline
\end{tabular}

Tabela 6.26 - Proporções médias de indicações para o período noturno com iluminação

\begin{tabular}{|c|c|c|c|c|c|}
\hline TIPO & $\mathbf{1}$ & $\mathbf{2}$ & $\mathbf{3}$ & $\mathbf{4}$ & $\mathbf{5}$ \\
\hline $\mathbf{1}$ & $50 \%$ & $0 \%$ & $3 \%$ & $0 \%$ & $0 \%$ \\
\hline $\mathbf{2}$ & $100 \%$ & $50 \%$ & $24 \%$ & $18 \%$ & $0 \%$ \\
\hline $\mathbf{3}$ & $97 \%$ & $76 \%$ & $50 \%$ & $0 \%$ & $0 \%$ \\
\hline $\mathbf{4}$ & $100 \%$ & $82 \%$ & $100 \%$ & $50 \%$ & $0 \%$ \\
\hline $\mathbf{5}$ & $100 \%$ & $100 \%$ & $100 \%$ & $100 \%$ & $50 \%$ \\
\hline
\end{tabular}

Tabela 6.27 - Escores z médios derivados da matriz de proporções médias para o período noturno com iluminação

\begin{tabular}{|c|c|c|c|c|c|c|c|c|}
\hline TIPO & $\mathbf{1}$ & $\mathbf{2}$ & $\mathbf{3}$ & $\mathbf{4}$ & $\mathbf{5}$ & Média & Escala Ajustada & ORDEM \\
\hline $\mathbf{1}$ & 0 & $-3,30$ & $-1,88$ & $-3,30$ & $-3,30$ & $-2,36$ & 0,00 & $\mathbf{5}^{\mathbf{0}}$ \\
\hline $\mathbf{2}$ & 3,30 & 0 & $-0,70$ & $-0,91$ & $-3,30$ & $-0,32$ & 2,04 & $\mathbf{3}^{\mathbf{0}}$ \\
\hline $\mathbf{3}$ & 1,88 & 0,70 & 0 & $-3,30$ & $-3,30$ & $-0,80$ & 1,56 & $\mathbf{4}^{\mathbf{0}}$ \\
\hline $\mathbf{4}$ & 3,30 & 0,91 & 3,30 & 0 & $-3,30$ & 0,84 & 3,20 & $\mathbf{2}^{\mathbf{0}}$ \\
\hline $\mathbf{5}$ & 3,30 & 3,30 & 3,30 & 3,30 & 0 & 3,30 & 5,66 & $\mathbf{1}^{\mathbf{0}}$ \\
\hline
\end{tabular}

Conforme indicam os valores da Tabela 6.27, a ordem de preferência dos entrevistados é a seguinte: placas 5, 4, 2, 3 e 1. A explicação é que o material retrorrefletivo faz com que o fundo e/ou os caracteres da placa brilhem com a incidência do feixe de luz, simulando o farol de um veículo, proporcionando maior contraste em relação ao meio ambiente parcialmente escuro, e, assim, melhorando a conspicuidade da placa; quanto mais eficiente o material retrorrefletivo, mais intenso 
o brilho e, por conseqüência, melhores são o contraste e a conspicuidade. Não se tem explicação para a ordem invertida das placas 3 e 4 .

\subsubsection{AVALIAÇÃO DA LEGIBILIDADE}

\section{- AMBIENTE ILUMINADO SEM INCIDÊNCIA DE FEIXE DE LUZ SOBRE AS PLACAS (SIMULAÇÃO DO PERÍODO DIURNO)}

Neste caso, os caracteres de todas as placas são legíveis e, portanto, apresentam legibilidade satisfatória.

Os resultados obtidos nos experimentos encontram-se nas Tabelas 6.28 a 6.30 .

Tabela 6.28 - Matriz de indicações para o período diurno

\begin{tabular}{|c|c|c|c|c|c|}
\hline TIPO & $\mathbf{1}$ & $\mathbf{2}$ & $\mathbf{3}$ & $\mathbf{4}$ & $\mathbf{5}$ \\
\hline $\mathbf{1}$ & - & 21 & 29 & 32 & 19 \\
\hline $\mathbf{2}$ & 12 & - & 19 & 24 & 20 \\
\hline $\mathbf{3}$ & 4 & 14 & - & 29 & 22 \\
\hline $\mathbf{4}$ & 1 & 9 & 4 & - & 20 \\
\hline $\mathbf{5}$ & 14 & 13 & 11 & 13 & - \\
\hline
\end{tabular}

Tabela 6.29 - Proporções médias de indicações para o período diurno

\begin{tabular}{|c|c|c|c|c|c|}
\hline TIPO & $\mathbf{1}$ & $\mathbf{2}$ & $\mathbf{3}$ & $\mathbf{4}$ & $\mathbf{5}$ \\
\hline $\mathbf{1}$ & $50 \%$ & $64 \%$ & $88 \%$ & $97 \%$ & $58 \%$ \\
\hline $\mathbf{2}$ & $36 \%$ & $50 \%$ & $58 \%$ & $73 \%$ & $61 \%$ \\
\hline $\mathbf{3}$ & $12 \%$ & $42 \%$ & $50 \%$ & $88 \%$ & $67 \%$ \\
\hline $\mathbf{4}$ & $3 \%$ & $27 \%$ & $12 \%$ & $50 \%$ & $61 \%$ \\
\hline $\mathbf{5}$ & $42 \%$ & $39 \%$ & $33 \%$ & $39 \%$ & $50 \%$ \\
\hline
\end{tabular}

Tabela 6.30 - Escores $\mathrm{z}$ médios derivados da matriz de proporções médias para o período diurno

\begin{tabular}{|c|c|c|c|c|c|c|c|c|}
\hline TIPO & $\mathbf{1}$ & $\mathbf{2}$ & $\mathbf{3}$ & $\mathbf{4}$ & $\mathbf{5}$ & Média & Escala Ajustada & ORDEM \\
\hline $\mathbf{1}$ & 0 & 0,35 & 1,17 & 1,88 & 0,19 & 0,72 & 1,40 & $\mathbf{1}^{\mathbf{0}}$ \\
\hline $\mathbf{2}$ & $-0,35$ & 0 & 0,19 & 0,60 & 0,27 & 0,14 & 0,82 & $\mathbf{2}^{\mathbf{0}}$ \\
\hline $\mathbf{3}$ & $-1,17$ & $-0,19$ & 0 & 1,17 & 0,43 & 0,05 & 0,73 & $\mathbf{3}^{\mathbf{0}}$ \\
\hline $\mathbf{4}$ & $-1,88$ & $-0,60$ & $-1,17$ & 0 & 0,27 & $-0,68$ & 0,00 & $\mathbf{5}^{\mathbf{0}}$ \\
\hline $\mathbf{5}$ & $-0,19$ & $-0,27$ & $-0,43$ & $-0,27$ & 0 & $-0,23$ & 0,45 & $\mathbf{4}^{\mathbf{0}}$ \\
\hline
\end{tabular}


Conforme indicam os valores da Tabela 6.30, a ordem de preferência dos entrevistados no tocante a legibilidade é a seguinte: 1, 2, 3, 5 e 4 . A explicação é que os materiais retrorrefletivos do fundo e/ou dos caracteres possuem na sua constituição elementos (microesferas de vidro ou prismas) para fazer a retrorreflexão da luz incidente, o que torna a visualização da cor, especialmente a cor branca, mais opaca durante o período diurno. Com isso diminui o contraste entre as cores, piorando a legibilidade. Não se tem explicação para a ordem invertida das placas $4 \mathrm{e}$ 5.

- AMBIENTE ESCURO COM INCIDÊNCIA DE FEIXE DE LUZ SOBRE AS PLACAS (SIMULAÇÃO DO PERÍODO NOTURNO EM VIAS NÃO ILUMINADAS)

Neste caso, somente as placas 2, 3, 4 e 5 são legíveis com a incidência direta do feixe de luz, isto é, apresentam legibilidade satisfatória. A visão da placa 1 (que não contém material refletivo) é um vulto negro de forma retangular, sem possibilidade de identificação dos caracteres e, portanto, sem legibilidade.

Os resultados obtidos nos experimentos encontram-se nas Tabelas 6.31 a 6.33 .

Tabela 6.31 - Matriz de indicações para o período noturno

\begin{tabular}{|c|c|c|c|c|c|}
\hline TIPO & $\mathbf{1}$ & $\mathbf{2}$ & $\mathbf{3}$ & $\mathbf{4}$ & $\mathbf{5}$ \\
\hline $\mathbf{1}$ & - & 1 & 0 & 0 & 2 \\
\hline $\mathbf{2}$ & 32 & - & 25 & 19 & 11 \\
\hline $\mathbf{3}$ & 33 & 8 & - & 2 & 0 \\
\hline $\mathbf{4}$ & 33 & 14 & 31 & - & 8 \\
\hline $\mathbf{5}$ & 31 & 22 & 33 & 25 & - \\
\hline
\end{tabular}

Tabela 6.32 - Proporções médias de indicações para o período noturno

\begin{tabular}{|c|c|c|c|c|c|}
\hline TIPO & $\mathbf{1}$ & $\mathbf{2}$ & $\mathbf{3}$ & $\mathbf{4}$ & $\mathbf{5}$ \\
\hline $\mathbf{1}$ & $50 \%$ & $3 \%$ & $0 \%$ & $0 \%$ & $6 \%$ \\
\hline $\mathbf{2}$ & $97 \%$ & $50 \%$ & $76 \%$ & $58 \%$ & $33 \%$ \\
\hline $\mathbf{3}$ & $100 \%$ & $24 \%$ & $50 \%$ & $6 \%$ & $0 \%$ \\
\hline $\mathbf{4}$ & $100 \%$ & $42 \%$ & $94 \%$ & $50 \%$ & $24 \%$ \\
\hline $\mathbf{5}$ & $94 \%$ & $67 \%$ & $100 \%$ & $76 \%$ & $50 \%$ \\
\hline
\end{tabular}


Tabela 6.33 - Escores z médios derivados da matriz de proporções médias para o período noturno

\begin{tabular}{|c|c|c|c|c|c|c|c|c|}
\hline TIPO & $\mathbf{1}$ & $\mathbf{2}$ & $\mathbf{3}$ & $\mathbf{4}$ & $\mathbf{5}$ & Média & Escala Ajustada & ORDEM \\
\hline $\mathbf{1}$ & 0 & $-1,88$ & $-3,30$ & $-3,30$ & $-1,55$ & $-2,00$ & 0,00 & $\mathbf{5}^{\mathbf{0}}$ \\
\hline $\mathbf{2}$ & 1,88 & 0 & 0,70 & 0,19 & $-0,43$ & 0,47 & 2,47 & $\mathbf{3}^{\mathbf{0}}$ \\
\hline $\mathbf{3}$ & 3,30 & $-0,70$ & 0 & $-1,55$ & $-3,30$ & $-0,45$ & 1,55 & $\mathbf{4}^{\mathbf{0}}$ \\
\hline $\mathbf{4}$ & 3,30 & $-0,19$ & 1,55 & 0 & $-0,70$ & 0,79 & 2,79 & $\mathbf{2}^{\mathbf{0}}$ \\
\hline $\mathbf{5}$ & 1,55 & 0,43 & 3,30 & 0,70 & 0 & 1,20 & 3,20 & $\mathbf{1}^{\mathbf{0}}$ \\
\hline
\end{tabular}

Conforme indicam os valores da Tabela 6.33, a ordem de preferência dos entrevistados é a seguinte: 5, 4, 2, 3 e 1. A explicação é que sob a incidência do feixe de luz, simulando o farol de um veículo, o material refletivo das letras proporciona contraste com o fundo brilhante confeccionado com material refletivo (caso das placas 3, 4 e 5). No caso da placa 2, as letras é que são refletivas e o fundo não. Quanto maior a retrorrefletividade da película das letras e tarjas, maiores o contraste e a legibilidade. Esta é a explicação para a placa 2 ser melhor avaliada do que a placa 3 , pois o contraste do fundo com a letras é muito superior, facilitando assim a leitura.

- AMBIENTE ESCURO COM ILUMINAÇÃO SUPERIOR E INCIDÊNCIA DE FEIXE DE LUZ SOBRE AS PLACAS (SIMULAÇÃO DE VIAS ILUMINADAS NO PERÍODO NOTURNO E VIAS NÃO ILUMINADAS DURANTE O NASCER E O POR DO SOL)

Neste caso, os caracteres de todas as placas são legíveis e, portanto, apresentam legibilidade satisfatória.

Os resultados obtidos nos experimentos encontram-se nas Tabelas 6.34 a 6.36 . 
Tabela 6.34 - Matriz de indicações para o período noturno com iluminação

\begin{tabular}{|c|c|c|c|c|c|}
\hline TIPO & $\mathbf{1}$ & $\mathbf{2}$ & $\mathbf{3}$ & $\mathbf{4}$ & $\mathbf{5}$ \\
\hline $\mathbf{1}$ & - & 8 & 0 & 0 & 3 \\
\hline $\mathbf{2}$ & 25 & - & 23 & 19 & 8 \\
\hline $\mathbf{3}$ & 33 & 10 & - & 2 & 0 \\
\hline $\mathbf{4}$ & 33 & 14 & 31 & - & 7 \\
\hline $\mathbf{5}$ & 30 & 25 & 33 & 26 & - \\
\hline
\end{tabular}

Tabela 6.35 - Proporções médias de indicações para o período noturno com iluminação

\begin{tabular}{|c|c|c|c|c|c|}
\hline TIPO & $\mathbf{1}$ & $\mathbf{2}$ & $\mathbf{3}$ & $\mathbf{4}$ & $\mathbf{5}$ \\
\hline $\mathbf{1}$ & $50 \%$ & $24 \%$ & $0 \%$ & $0 \%$ & $9 \%$ \\
\hline $\mathbf{2}$ & $76 \%$ & $50 \%$ & $70 \%$ & $58 \%$ & $24 \%$ \\
\hline $\mathbf{3}$ & $100 \%$ & $30 \%$ & $50 \%$ & $6 \%$ & $0 \%$ \\
\hline $\mathbf{4}$ & $100 \%$ & $42 \%$ & $94 \%$ & $50 \%$ & $21 \%$ \\
\hline $\mathbf{5}$ & $91 \%$ & $76 \%$ & $100 \%$ & $79 \%$ & $50 \%$ \\
\hline
\end{tabular}

Tabela 6.36 - Escores z médios derivados da matriz de proporções médias para o período noturno com iluminação

\begin{tabular}{|c|c|c|c|c|c|c|c|c|}
\hline TIPO & $\mathbf{1}$ & $\mathbf{2}$ & $\mathbf{3}$ & $\mathbf{4}$ & $\mathbf{5}$ & Média & Escala Ajustada & ORDEM \\
\hline $\mathbf{1}$ & 0 & $-0,70$ & $-3,30$ & $-3,30$ & $-1,34$ & $-1,73$ & 0,00 & $\mathbf{5}^{\mathbf{0}}$ \\
\hline $\mathbf{2}$ & 0,70 & 0 & 0,52 & 0,19 & $-0,70$ & 0,14 & 1,87 & $\mathbf{3}^{\mathbf{0}}$ \\
\hline $\mathbf{3}$ & 3,30 & $-0,52$ & 0 & $-1,55$ & $-3,30$ & $-0,41$ & 1,32 & $\mathbf{4}^{\mathbf{0}}$ \\
\hline $\mathbf{4}$ & 3,30 & $-0,19$ & 1,55 & 0 & $-0,80$ & 0,77 & 2,50 & $\mathbf{2}^{\mathbf{0}}$ \\
\hline $\mathbf{5}$ & 1,34 & 0,70 & 3,30 & 0,80 & 0 & 1,23 & 2,96 & $\mathbf{1}^{\mathbf{0}}$ \\
\hline
\end{tabular}

Conforme indicam os valores da Tabela 6.36, a ordem de preferência dos entrevistados no tocante é a seguinte: $5,4,2,3$ e 1 . A explicação é que o material retrorrefletivo do fundo e tarjas se sobressai mesmo com iluminação externa, e que quanto maior a eficiência do material retrorrefletivo, maior a facilidade de identificação dos caracteres. A explicação para a preferência da placa tipo 2 em relação a da tipo 3 deve-se ao fato da placa tipo 3 ter material com igual retrorrefletividade no fundo e nas letras, sendo menor o contraste se comparado com a placa 2 . 


\subsection{AVALIAÇÃO DA RETRORREFLETIVIDADE (EXPERIMENTO 3)}

\section{- PLACA DE REGULAMENTAÇÃ̃ (R19 - 20 KM/H)}

Os resultados obtidos nos experimentos encontram-se nas Tabela 6.37.

Tabela 6.37 - Valores de Retrorrefletividade ( $\left.\mathrm{mcd} / \mathrm{lux} / \mathrm{m}^{2}\right)$

\begin{tabular}{|c|c|c|c|c|c|c|c|c|c|c|c|c|c|c|c|c|c|c|}
\hline \multirow[b]{2}{*}{ TIPO } & \multicolumn{6}{|c|}{ BRANCO (FUNDO) } & \multicolumn{6}{|c|}{ VERMELHO (ORLA) } & \multicolumn{6}{|c|}{ PRETO (CARACTERES) } \\
\hline & 1 & 2 & 3 & 4 & 5 & M & 1 & 2 & 3 & 4 & 5 & $\mathrm{M}$ & 1 & 2 & 3 & 4 & 5 & M \\
\hline 1 & 1 & 1 & 0 & 0 & 0 & $\mathbf{0}$ & 0 & 0 & 0 & 1 & 0 & $\mathbf{0}$ & - & - & - & - & - & - \\
\hline 2 & 0 & 0 & 1 & 0 & 0 & $\mathbf{0}$ & 55 & 57 & 60 & 59 & 59 & 58 & 36 & 37 & 44 & 37 & 37 & 38 \\
\hline 3 & 132 & 143 & 150 & 139 & 131 & 139 & 36 & 34 & 38 & 36 & 31 & 35 & - & - & - & - & - & - \\
\hline 4 & 836 & 679 & 754 & 733 & 810 & 762 & 215 & 241 & 230 & 161 & 259 & 221 & - & - & - & - & - & - \\
\hline 5 & 999 & 957 & 935 & 981 & 965 & 967 & 328 & 291 & 299 & 330 & 315 & 313 & - & - & - & - & - & - \\
\hline
\end{tabular}

Com relação aos valores apresentados na Tabela 6.37, cabem as seguintes observações:

- A placa 1 não possui elementos retrorrefletivos e, portanto, não atende os requisitos para ser empregada em vias não iluminadas.

- A placa tipo 2 não possui o fundo retrorrefletivo e, portanto, não atende os requisitos para ser empregada em vias não iluminadas. Adicionalmente, nesta placa são empregadas letras pretas refletivas que não atendem o especificado na norma NBR 14.644 (os caracteres de cor preta devem ser de material não retrorrefletivo - tipo IV).

- As películas refletivas de cor branca tipo IA empregadas na placa 3 apresentam um índice médio de retrorrefletividade igual a 139, portanto 2,0 vezes maior que 70 - valor mínimo especificado pela NBR 14.644. As películas refletivas de cor branca tipo III empregadas na placa 4 apresentam um índice médio de retrorrefletividade igual a 762, portanto 2,1 vezes maior que 360 - valor mínimo especificado pela NBR 14.644. As películas refletivas de cor branca tipo X empregadas na placa 5 apresentam um índice médio de retrorrefletividade igual a 967, portanto 2,3 vezes maior que 425 - valor mínimo especificado pela NBR 14.644. O valor da retrorrefletividade da película tipo X (967) mostrou-se 1,3 
vezes maior do que a película tipo III (762) e 7,0 vezes maior do que a tipo IA (139); a do tipo III (762) mostrou-se 5,5 vezes maior do que a do tipo IA (139).

- As películas refletivas de cor vermelha tipo IA empregadas nas placas 2 e 3 apresentam um índice médio de retrorrefletividade igual a 47, portanto 3,4 vezes maior que 14 - valor mínimo especificado pela NBR 14.644. As películas refletivas de cor vermelha tipo III empregadas na placa 4 apresentam um índice médio de retrorrefletividade igual a 221, portanto 3,4 vezes maior que 65 - valor mínimo especificado pela NBR 14.644. As películas refletivas de cor vermelha tipo $\mathrm{X}$ empregadas na placa 5 apresentam um índice médio de retrorrefletividade igual a 313, portanto 3,0 vezes maior que 106 - valor mínimo especificado pela NBR 14.644. O valor da retrorrefletividade da película tipo X (313) mostrou-se 1,4 vezes maior do que a película tipo III (221) e 6,7 vezes maior do que a tipo IA (47); a do tipo III (221) mostrou-se 4,7 vezes maior do que a do tipo IA (47).

\section{- PLACA DE INDICAÇÃO DE LOCALIDADE (FÓRUM)}

Os resultados obtidos nos experimentos encontram-se nas Tabela 6.38.

Tabela 6.38 - Valores de Retrorrefletividade ( $\left.\mathrm{mcd} / \mathrm{lux} / \mathrm{m}^{2}\right)$

\begin{tabular}{|c|c|c|c|c|c|c|c|c|c|c|c|c|}
\multicolumn{1}{|c|}{ TIPO } & 1 & 2 & 3 & 4 & 5 & M & 1 & 2 & 3 & 4 & 5 & M \\
\hline $\mathbf{1}$ & 0 & 1 & 0 & 0 & 1 & $\mathbf{0}$ & 0 & 0 & 0 & 1 & 0 & $\mathbf{0}$ \\
\hline $\mathbf{2}$ & 0 & 0 & 1 & 0 & 1 & $\mathbf{0}$ & 137 & 140 & 138 & 133 & 140 & $\mathbf{1 3 8}$ \\
\hline $\mathbf{3}$ & 22 & 22 & 22 & 19 & 19 & $\mathbf{2 1}$ & 135 & 137 & 135 & 134 & 141 & $\mathbf{1 3 6}$ \\
\hline $\mathbf{4}$ & 28 & 27 & 27 & 28 & 26 & $\mathbf{2 7}$ & 583 & 530 & 545 & 561 & 632 & $\mathbf{5 7 0}$ \\
\hline $\mathbf{5}$ & 117 & 107 & 112 & 107 & 115 & $\mathbf{1 1 2}$ & 879 & 880 & 952 & 994 & 979 & $\mathbf{9 3 7}$ \\
\hline
\end{tabular}

Com relação aos valores apresentados na Tabela 6.37, cabem as seguintes observações:

- A placa tipo 1 não possui elementos retrorrefletivos e, portanto, não cumpre os requisitos para ser empregada nas vias não iluminadas.

- A placa tipo 2 não possui o fundo retrorrefletivo e, portanto, também não cumpre os requisitos para ser empregada em vias não iluminadas. 
- As películas refletivas de cor azul tipo IA empregadas nas placas 3 e 4 apresentam um índice médio de retrorrefletividade igual a 24 , portanto 6,0 vezes maior que 4 - valor mínimo especificado pela NBR 14.644. As películas refletivas de cor azul tipo $\mathrm{X}$ empregadas na placa 5 apresentam um índice médio de retrorrefletividade igual a 112 , portanto 4,3 vezes maior que 26 - valor mínimo especificado pela NBR 14.644. O valor da retrorrefletividade da película tipo X (112) mostrou-se 4,7 vezes maior do que a película tipo IA (24).

- As películas refletivas de cor branca tipo IA empregadas nas placas 2 e 3 apresentam um índice médio de retrorrefletividade igual a 137, portanto 2,0 vezes maior que 70 - valor mínimo especificado pela NBR 14.644. As películas refletivas de cor branca tipo III empregadas na placa 4 apresentam um índice médio de retrorrefletividade igual a 570, portanto 1,6 vezes maior que 360 - valor mínimo especificado pela NBR 14.644. As películas refletivas de cor branca tipo $\mathrm{X}$ empregadas na placa 5 apresentam um índice médio de retrorrefletividade igual a 937, portanto 2,2 vezes maior que 425 - valor mínimo especificado pela NBR 14.644. O valor da retrorrefletividade da película tipo X (937) mostrou-se 1,6 vezes maior do que a película tipo III (570) e 6,8 vezes maior do que a tipo IA (137); a do tipo III (570) mostrou-se 4,2 vezes maior do que a do tipo IA (137). 


\section{CONCLUSÕES}

\subsection{SOBRE A PLACA DE REGULAMENTAÇÃO}

Uma síntese dos resultados nos experimentos realizados com a placa de regulamentação $(20 \mathrm{~km} / \mathrm{h})$ é apresentada na Tabela 7.1.

Tabela 7.1 - Síntese dos resultados para a placa de regulamentação

\begin{tabular}{|c|c|c|c|c|c|c|}
\hline & Placa & Tipo 1 & Tipo 2 & Tipo 3 & Tipo 4 & Tipo 5 \\
\hline & Material da placa & $\begin{array}{l}\text { Fundo semi- } \\
\text { brilho e tarja } \\
\text { e letras não } \\
\text { refletivas }\end{array}$ & $\begin{array}{l}\text { Fundo semi- } \\
\text { brilho e tarja } \\
\quad \text { e letras } \\
\text { refletivas IA }\end{array}$ & $\begin{array}{c}\text { Fundo } \\
\text { refletivo IA, } \\
\text { tarja refletiva } \\
\text { IA e letras } \\
\text { não refletivas } \\
\text { IV }\end{array}$ & $\begin{array}{c}\text { Fundo } \\
\text { refletivo III, } \\
\text { tarja refletiva } \\
\text { III e letras } \\
\text { não refletivas } \\
\text { IV }\end{array}$ & $\begin{array}{c}\text { Fundo } \\
\text { refletivo X, } \\
\text { tarja refletiva } \\
\text { X e letras não } \\
\text { refletivas IV }\end{array}$ \\
\hline $\begin{array}{c}\text { Condição } \\
\text { de } \\
\text { operação }\end{array}$ & $\begin{array}{l}\text { Avaliação da } \\
\text { retrorrefletividade }\end{array}$ & $\begin{array}{c}\text { Péssimo } \\
\text { (inexistente) }\end{array}$ & $\begin{array}{c}\text { Péssimo } \\
\text { (inexistente } \\
\text { no fundo) }\end{array}$ & Regular & Bom & Ótimo \\
\hline \multirow{2}{*}{$\begin{array}{c}\text { Durante o } \\
\text { dia }\end{array}$} & Conspicuidade & $1^{\mathrm{O}}$ & $2^{\circ}$ & $3^{\circ}$ & $4^{\circ}$ & $5^{\circ}$ \\
\hline & Legibilidade & $1^{\mathrm{o}}$ & $2^{\circ}$ & $3^{\circ}$ & $5^{\circ}$ & $4^{0}$ \\
\hline \multirow{2}{*}{$\begin{array}{c}\text { Via não } \\
\text { iluminada } \\
\text { à noite }\end{array}$} & Conspicuidade & Insatisfatória & Insatisfatória & $3^{\circ}$ & $2^{0}$ & $1^{\mathrm{O}}$ \\
\hline & Legibilidade & Insatisfatória & $4^{\circ}$ & $3^{\circ}$ & $2^{\mathrm{o}}$ & $1^{\mathrm{o}}$ \\
\hline \multirow{2}{*}{$\begin{array}{c}\text { Via } \\
\text { iluminada } \\
\text { à noite }\end{array}$} & Conspicuidade & $5^{\circ}$ & $4^{0}$ & $3^{\circ}$ & $2^{0}$ & $1^{\mathrm{O}}$ \\
\hline & Legibilidade & Insatisfatória & Insatisfatória & $3^{o}$ & $2^{\mathrm{o}}$ & $1^{\mathrm{o}}$ \\
\hline
\end{tabular}

Na Figura 7.1 são mostrados os gráficos dos resultados obtidos. 

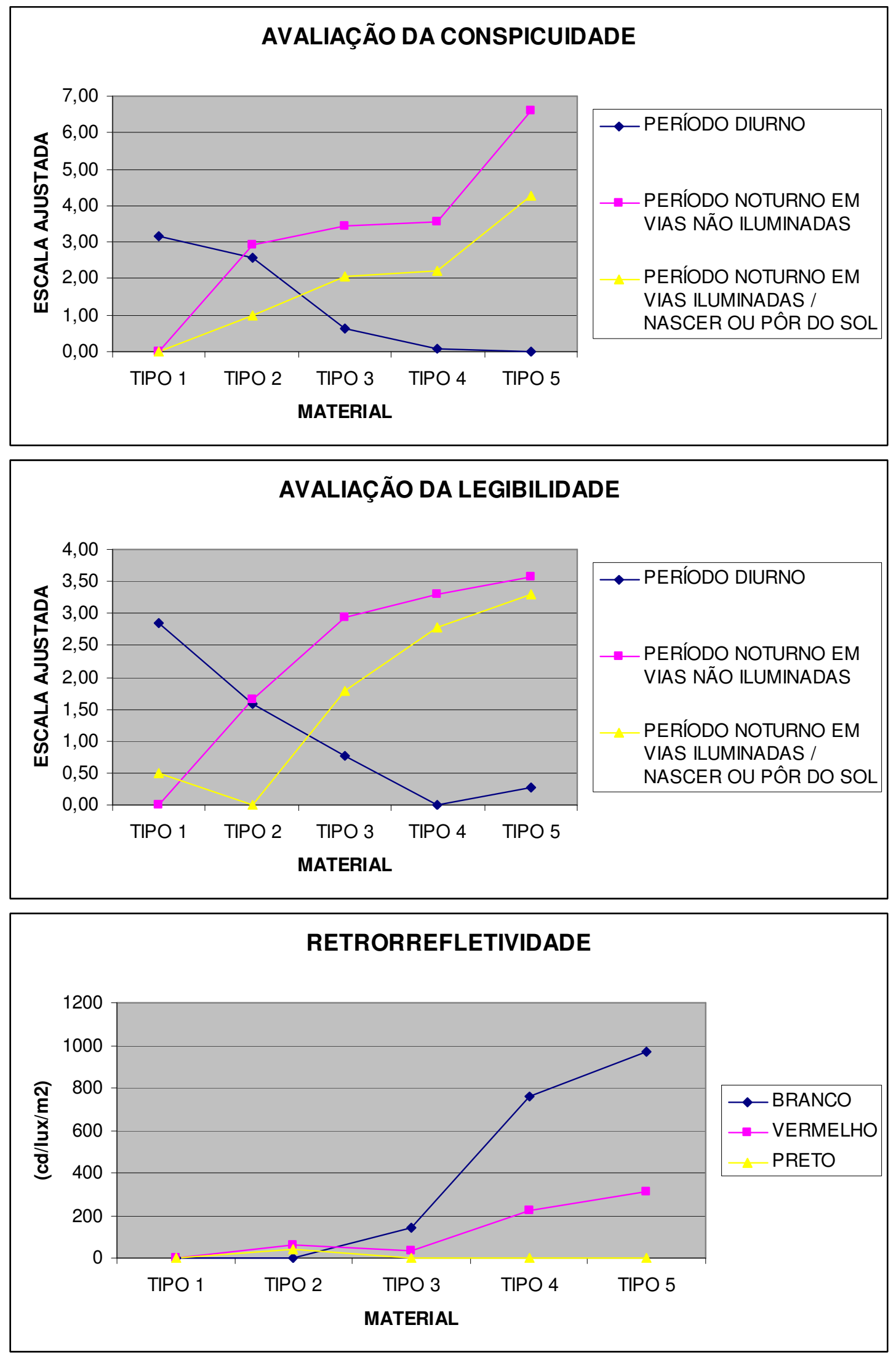

Figura 7.1 - Gráficos dos resultados obtidos para a placa de regulamentação 
No que concerne a placa de regulamentação $(20 \mathrm{~km} / \mathrm{h})$, os seguintes principais fatos podem ser depreendidos das informações apresentadas:

- No período diurno todas as placas apresentam desempenho satisfatório. No que se refere ao quesito conspicuidade, a ordem de preferência é a seguinte: placas 1, 2, 3, 4 e 5. No que diz respeito ao quesito legibilidade, a ordem de preferência é a seguinte: placas $1,2,3,5$ e 4 .

- No período noturno, tanto nas vias não iluminadas como nas iluminadas as placas 1 e 2 não apresentam desempenho satisfatório. A ordem de preferência sob a ótica dos dois quesitos (conspicuidade e legibilidade), desconsiderando as placas 1 e 2, é a seguinte: placas 5, 4 e 3.

Como as placas de regulamentação (e advertência) devem apresentar adequada conspicuidade e legibilidade tanto durante o dia como à noite, não é recomendado o emprego das placas dos tipos 1 e 2, mas apenas as placas dos tipos 3 , 4 e 5. Tecnicamente, considerando ser a condição noturna mais crítica, a ordem de preferência na utilização das placas, seja a via iluminada ou não, é a seguinte; placas 5,4 e 3 . 


\subsection{SOBRE A PLACA DE INDICAÇÃO DE LOCALIDADE}

Uma síntese dos resultados nos experimentos realizados com a placa de indicação de localidade (palavra Fórum) é apresentada na Tabela 7.2.

Tabela 7.2 - Síntese dos resultados para a placa de indicação de localidade

\begin{tabular}{|c|c|c|c|c|c|c|}
\hline & Placa & Tipo 1 & Tipo 2 & Tipo 3 & Tipo 4 & Tipo 5 \\
\hline & Material da placa & $\begin{array}{l}\text { Fundo semi- } \\
\text { brilho e tarja } \\
\text { e letras não } \\
\text { refletivas }\end{array}$ & $\begin{array}{l}\text { Fundo semi- } \\
\text { brilho e tarja } \\
\quad \text { e letras } \\
\text { refletivas IA }\end{array}$ & $\begin{array}{l}\text { Fundo } \\
\text { refletivo IA, } \\
\text { tarja e letras } \\
\text { refletivas IA }\end{array}$ & $\begin{array}{l}\text { Fundo } \\
\text { refletivo IA, } \\
\text { tarja e letras } \\
\text { refletivas III }\end{array}$ & $\begin{array}{l}\text { Fundo } \\
\text { refletivo X, } \\
\text { tarja e letras } \\
\text { refletivas X }\end{array}$ \\
\hline $\begin{array}{c}\text { Condição } \\
\text { de } \\
\text { operação }\end{array}$ & $\begin{array}{l}\text { Avaliação da } \\
\text { retrorrefletividade }\end{array}$ & $\begin{array}{c}\text { Péssimo } \\
\text { (inexistente) }\end{array}$ & $\begin{array}{c}\text { Péssimo } \\
\text { (inexistente } \\
\text { no fundo) }\end{array}$ & Regular & Bom & Ótimo \\
\hline \multirow{2}{*}{$\begin{array}{c}\text { Durante o } \\
\text { dia }\end{array}$} & Conspicuidade & $1^{\mathrm{o}}$ & $3^{\circ}$ & $2^{0}$ & $5^{\circ}$ & $4^{0}$ \\
\hline & Legibilidade & $1^{\mathrm{o}}$ & $2^{\circ}$ & $3^{\circ}$ & $5^{\circ}$ & $4^{\circ}$ \\
\hline \multirow{2}{*}{$\begin{array}{c}\text { Via não } \\
\text { iluminada } \\
\text { à noite }\end{array}$} & Conspicuidade & Insatisfatória & Insatisfatória & $3^{\circ}$ & $2^{\circ}$ & $1^{\mathrm{o}}$ \\
\hline & Legibilidade & Insatisfatória & $3^{\circ}$ & $4^{o}$ & $2^{\mathrm{o}}$ & $1^{\mathrm{o}}$ \\
\hline \multirow{2}{*}{$\begin{array}{c}\text { Via } \\
\text { iluminada } \\
\text { à noite }\end{array}$} & Conspicuidade & $5^{\circ}$ & $3^{0}$ & $4^{\circ}$ & $2^{\circ}$ & $1^{\mathrm{o}}$ \\
\hline & Legibilidade & $5^{\circ}$ & $3^{o}$ & $4^{\circ}$ & $2^{o}$ & $1^{\mathrm{o}}$ \\
\hline
\end{tabular}

Na Figura 7.2 são mostrados os gráficos dos resultados obtidos. 

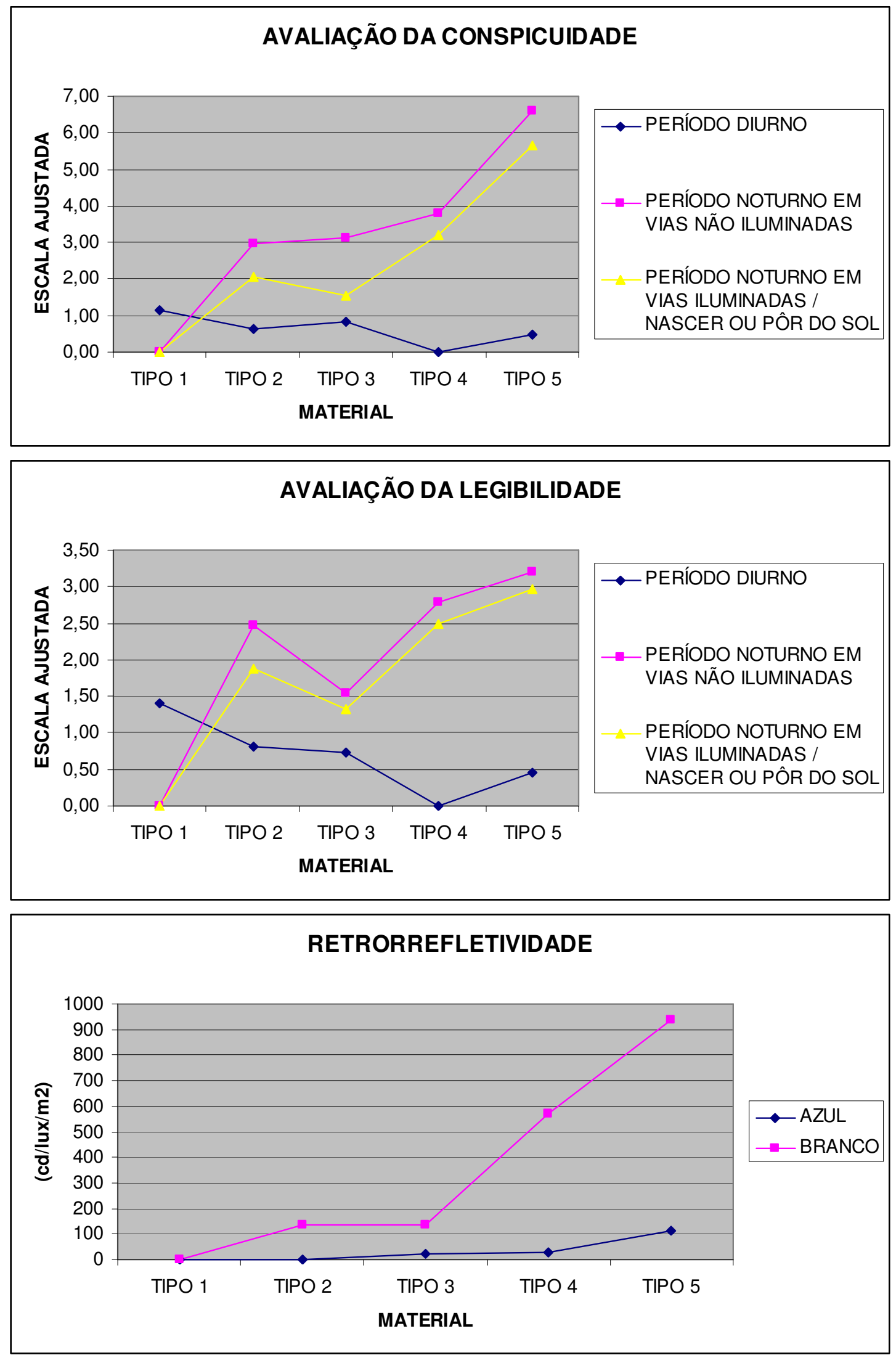

Figura 7.2 - Gráficos dos resultados obtidos para a placa de indicação de localidade. 
No que concerne a placa de indicação (palavra Fórum), os seguintes principais fatos podem ser depreendidos das informações apresentadas:

- No período diurno todas as placas apresentam desempenho satisfatório. No que se refere ao quesito conspicuidade, a ordem de preferência é a seguinte: placas 1, 3, 2, 5 e 4 . No que diz respeito ao quesito legibilidade, a ordem de preferência é a seguinte: placas $1,2,3,5$ e 4 .

- No período noturno, nas vias não iluminadas a placa 1 não apresenta desempenho satisfatório. A ordem de preferência sob a ótica do quesito legibilidade, desconsiderando a placa 1 é a seguinte: placas 5, 4, 2 e 3. No que diz respeito ao quesito conspicuidade, desconsiderando as placas 1 e 2, a ordem de preferência é a seguinte: 5,4 e 3 .

- No período noturno, nas vias iluminadas todas as placas apresentam desempenho satisfatório. A ordem de preferência sob a ótica dos dois quesitos (conspicuidade e legibilidade) é a seguinte: placas 5, 4, 2, 3 e 1.

Como as placas indicativas devem apresentar adequada conspicuidade e legibilidade tanto durante o dia como à noite, nas vias não iluminadas não é recomendado o emprego das placas do tipo 1 e 2 . Apesar da placa do tipo 2 possuir legibilidade ela não oferece conspicuidade satisfatória, pois não reflete a cor de fundo da placa, o que também pode deixar o motorista indeciso. Tecnicamente, considerando ser a condição noturna mais crítica, a ordem de preferência na utilização das placas é a seguinte; placas 5, 4 e 3. No caso das vias iluminadas, todos os tipos de placas indicativas podem ser empregados. 


\subsection{OBSERVAÇÕES GERAIS}

Os experimentos foram realizados com os sujeitos em posição estática, não havendo experimentos dinâmicos que simulassem a velocidade dos veículos ao se aproximarem dos sinais verticais.

Os tamanhos das amostras utilizadas na elaboração dos experimentos sobre a conspicuidade e legibilidade não apresentam representatividade estatística em nível de significância adequado. Dessa forma, os resultados obtidos devem ser vistos apenas como sinalizadores de tendências.

Sendo o custo das placas um fator importante na decisão do tipo de placa a ser utilizada na Figura 7.3 é mostrado um gráfico comparativo com o custo médio dos tipos de placas analisados.

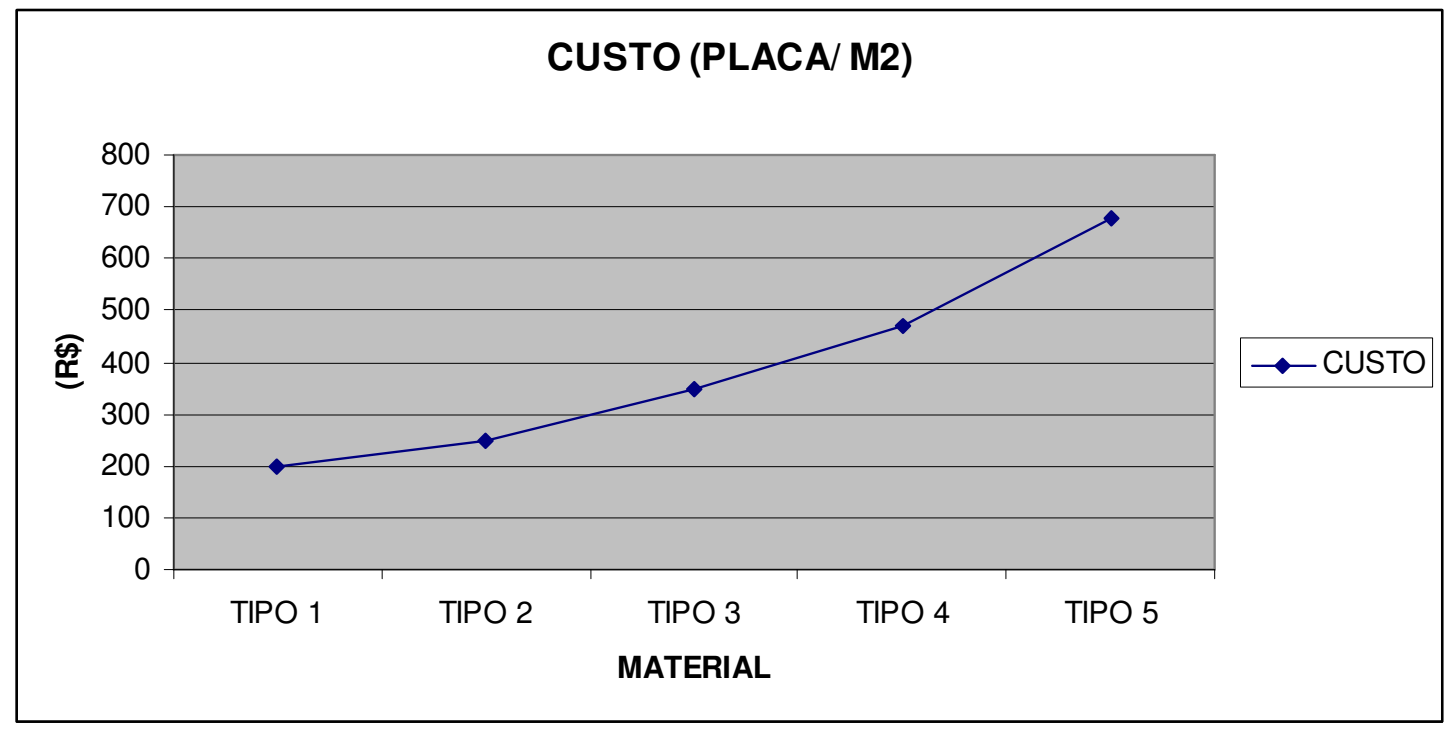

Figura 7.3 - Gráfico com o custo das placas.

Pode-se verificar uma diferença significativa entre os custos dos materiais, chegando a aproximadamente 3,5 vezes entre os tipos 1 e 5. Porém, como verificado nos gráficos comparativos do experimento 1 e 2 , as placas do tipo 5 chegam a ser aproximandamente 7 vezes superiores em performance do que as placas tipo $1 . \mathrm{Na}$ escolha, deve-se levar em consideração além do desempenho técnico e do custo outros fatores, como: volume diário médio (VDM), características geométricas da via, velocidade, número de faixas, complexidade do local, etc. 
Com base nos resultados obtidos e na bibliografia estudada, podem ser feitas as seguintes recomendações de uso dos tipos de materiais das placas:

- Vias iluminadas (cenário normalmente encontrado nas cidades): para as vias principais deve-se utilizar no mínimo a película refletiva tipo I (Grau Técnico), tendo como ideal as películas tipo III (Alta Intensidade Prismático) ou tipo X (Grau Diamante ou Omniview). Para vias de pouco movimento pode-se utilizar somente a película refletiva tipo I (Grau Técnico).

- Vias não iluminadas (cenário normalmente encontrado nas rodovias): deve-se utilizar no mínimo a película refletiva tipo I (Grau Técnico), tendo como ideal as películas refletivas tipo III (Alta Intensidade Prismático) ou tipo X (Grau Diamante ou Omniview). Para as rodovias com duas faixas ou mais e elevado VDM, deve-se utilizar no mínimo a película refletiva tipo III.

- Placas aéreas (instaladas em pórticos, semipórticos ou bandeiras): por estarem em local que recebe pouca incidência do farol dos veículos, deve-se utilizar no mínimo a película refletiva tipo I (Grau Técnico) de fundo e a película refletiva tipo III (Alta Intensidade Prismática) para as letras e tarjas. Para as cidades ou rodovias, com vias de duas faixas ou mais e elevado VDM, deve-se utilizar a película refletiva tipo III de fundo e a película refletiva tipo X (Grau Diamante ou Omniview) para as letras e tarjas.

- Pontos críticos (cidades ou rodovias): são locais em que é registrado um alto índice de acidentes. Para estes locais devem ser utilizados os melhores materiais disponíveis no mercado, visando solucionar de forma efetiva o problema. Para tanto, além de um projeto especial para o local, deve ser utilizado as películas refletivas tipo X (Grau Diamante ou Omniview) nas placas de sinalização. Um bom exemplo da eficiência do uso de materiais refletivos de alta performance (tipo X - Grau Diamante ou Omniview) nestes locais foi verificado na cidade de Caçapava, no ano de 2003. Os pontos críticos mapeados pelo Departamento de Transporte da cidade receberam sinalização com película de alta performance e no período de dois meses seguintes a implantação não registraram nenhum acidente. 


\section{REFERÊNCIAS BIBLIOGRAFICAS}

ABNT - Associação Brasileira de Normas Técnicas, NBR 14644 - Sinalização Vertical Viária - Películas - Requisitos.

ABNT - Associação Brasileira de Normas Técnicas, NBR 15426 - Sinalização Vertical Viária - Métodos de ensaio padrão para medição de películas retrorrefletivas utilizando um retrorrefletômetro portátil.

CARLSON, P. J.; HAWKINGS, JR. H. G. (2003) Minimum Retroreflectivity Levels of Overhead Guide Signs and Street-Name Signs, Report No. FHWA/RD-03-082, Washington, DC.

CNT (2007) Confederação Nacional do Transporte. Pesquisa Rodoviária. Relatório Gerencial. Brasília, DF.

CÓDIGO DE TRÂNSITO BRASILEIRO - Lei no 9503, de setembro de 1997 atualizado com a Lei no 9602 de 21 de janeiro de 1998. Ed. 2 EDIPRO. São Paulo - SP.

COLE \& JENKINS (1982) Conspicuity of traffic control devices. Australian Road Research, 12 (04) p. 223-238.

DA SILVA, J. A.; ROZESTRATEN, R. (2000) Psicofísica e Percepção: Manual Prático. Material apostilado utilizado na disciplina de Psicologia Experimental III: Psicofísica e Percepção. FFCLRP-USP, Ribeirão Preto - SP.

DEPARTAMENTO DE ESTRADAS DE RODAGEM DO ESTADO DE SÃO PAULO (2006) Manual de Sinalização Rodoviária - Projeto, vol. 1.

DEPARTAMENTO DE ESTRADAS DE RODAGEM DO ESTADO DE SÃO PAULO (2006) Manual de Sinalização Rodoviária - Confecção dos sinais, vol. 2.

DEPARTAMENTO DE ESTRADAS DE RODAGEM DO ESTADO DE SÃO PAULO (2006) Manual de Sinalização Rodoviária - Obras, serviços de conservação e emergência, vol. 3 .

FERRAZ, A. C. P.; FORTES, F. Q.; SIMÕES, F. A. (1999) Engenharia de Tráfego Urbano - Fundamentos Práticos. São Carlos, EESC. 
FERRAZ, A. C. P.; PIERRE; M. A.; FORTES, F. Q. (1997) Innovaciones en lá Señalización Viária en São Carlos - Brasil. VIII Congresso Chileno De Ingenieria De Transporte. Santiago, Chile.

FERRAZ, A. C. P.; RAIA JR. A. A.; BEZERRA, B. S. - Segurança no Trânsito. Editora São Francisco. Ribeirão Preto, 2008.

FHWA (2003) Federal Highway Administration. Maintaining Traffic Sign Retroreflectivity. Washington, D.C.

FONTANA, A. M. (2005) Estudo psicofísico sobre conspicuidade, estética e harmonia ambiental de sinais de trânsito. 142p. Tese (Doutorado) - Escola de Engenharia de São Carlos, Universidade de São Paulo.

FONTANA, A. M. (2001) Proposta de alterações em alguns sinais de trânsito para melhorar o impacto visual - Avaliação utilizando método psicofísico. 105p. Dissertação (Mestrado) - Escola de Engenharia de São Carlos, Universidade de São Paulo.

FUNDAÇÃO ROYAL AUTOMOBILE CLUB (2004) Pesquisa de acidentes de trânsito na Austrália. http://carsale.uol.com.br/noticias/ed101not8031.shtml acessado em 16 de julho de 2007.

GRSP - Global Road Safety Partnership

http://www.grsproadsafety.org - acessado em 12 de abril de 2006.

IPEA (2003) Impactos sociais e econômicos dos acidentes de trânsito nas aglomerações urbanas. Síntese da pesquisa, Brasília.

IPEA (2006) Impactos sociais e econômicos dos acidentes de trânsito nas rodovias brasileiras. Relatório executivo, Brasília.

IRTAD - International Road Traffic and Accident Database. http://www.irtad.net

KAWAMOTO, E. (1987) Um novo enfoque do processo da escolha em transporte com tratamento baseado na psicofísica multidimensional. 126p. São Carlos. Tese (Doutorado). Escola de Engenharia de São Carlos. Universidade de São Paulo.

MACE, D.J., P.M. GARVEY, R.F. HECKARD (1994) Relative Visibility of Increased Legend Size vs.Brighter Materials for Traffic Signs, Report No. FHWA-RD-94-035, FHWA, Washington,DC. 
MACE, D.J., R.B. KING, G.W. DAUBER (1985) Sign Luminance Requirements for Various Background Complexities, Report No. FHWA/RD-85/056, FHWA, Washington, DC.

MISE, A. K. (2000) Avaliação das inovações introduzidas na sinalização viária da cidade de São Carlos. São Carlos. 47p. Relatório de Pesquisa da FAPESP (Iniciação Científica) - Escola de Engenharia de São Carlos, Universidade de São Paulo.

MORAES, R. D. (2002) Estudo do impacto visual de alguns sinais horizontais de trânsito - avaliação utilizando métodos da psicofísica. 122p. Dissertação (Mestrado) - Escola de Engenharia de São Carlos, Universidade de São Paulo.

MORALES, J. (1987) "Retroreflective Requirements for Traffic Signs - A Stop Sign Case Study," Public Roads, FHWA, Washington, DC.

MOREIRA, H.; MENEGON R. (2003) Sinalização Horizontal.

MORI, M.; ABDEL-HALIN, M. H. (1981) Road sign recongnition and nonrecognition. Accidents Analysis and Prevention. N. 13, p. 105-115.

OMS (2004) Organização Mundial da Saúde. Relatório Mundial sobre a prevenção das mortes e lesões causadas por acidentes de trânsito.

RESOLUÇÃO 160/04 do CONTRAN - Anexo II do CTB.

RESOLUÇÃO 180/05 do CONTRAN - Manual Brasileiro de Sinalização de Trânsito. Sinalização Vertical de Regulamentação, vol. 1.

RESOLUÇÃO 236/07 do CONTRAN - Manual Brasileiro de Sinalização de Trânsito. Sinalização Horizontal, vol. 4.

RESOLUÇÃO 243/07 do CONTRAN - Manual Brasileiro de Sinalização de Trânsito. Sinalização Vertical de Advertência, vol. 2.

SANTOS, R. A. (1994) Proposta para o exame teórico de habilitação de condutores. 174p. São Paulo. Tese (Doutorado) Instituto de Psicologia. Universidade de São Paulo.

SIVAK, M., P.L. OLSON (1985) "Optimal and Minimal Luminance Characteristics for Retroreflective Highway Signs," Transportation Research Record 1027, TRB, NRC, Washington, DC. 
TNO (2000) Minimum required night-time luminance of retroreflective traffic signs. TNO Report TM-00-C029. Netherlands Organisation for Applied Scientific Research.

WHO - World Health Organization. World report on road traffic injury prevention. Geneva, 2004. 


\section{ANEXOS}

\section{ANEXO 1}

\section{EXPERIMENTO № $\mathbf{0}$}

\section{Avaliação da Conspicuidade e Legibilidade das Placas de Regulamentação}

\begin{tabular}{|c|c|c|c|c|}
\hline \multicolumn{5}{|l|}{ NOME: } \\
\hline \multicolumn{5}{|l|}{ Idade: } \\
\hline Sexo: & ( ) feminino & ( ) masculin & & \\
\hline $\begin{array}{l}\text { Grau de } \\
\text { Instrução: }\end{array}$ & $\begin{array}{c}\text { ( ) } \\
\text { pós-graduação }\end{array}$ & $\begin{array}{c}\text { ( ) } \\
\text { graduação }\end{array}$ & $\begin{array}{c}(\quad) \\
\text { ensino médio }\end{array}$ & $\begin{array}{l}\text { ( ) ensino } \\
\text { fundamental }\end{array}$ \\
\hline Motorista: & ( ) sim & ( ) não & & \\
\hline
\end{tabular}

Esta é uma pesquisa para verificar qual placa tem maior impacto visual (chama mais a atenção) e qual tem melhor legibilidade (é mais fácil de entender os símbolos e letras).

Será mostrado para você um conjunto de sinais, os quais você deverá comparar e escolher de acordo com a sua preferência.

Para que sua escolha seja computada, ela funcionará da seguinte maneira:

Com relação ao impacto visual:

1 - o sinal com maior impacto visual

0 - o sinal com menor impacto visual

Com relação à legibilidade:

1 - o sinal com melhor legibilidade

0 - o sinal com pior legibilidade 
Estes valores deverão ser marcados nas tabelas correspondentes aos sinais analisados.

Para cada conjunto de estímulos (sinais) é apresentada uma tabela que será preenchida à medida que estes forem mostrados.

Os seus dados pessoais não serão divulgados.

Obrigado pela sua contribuição.

Estímulos: Período Diuno (luz acesa) / Noturno (luz apagada) / Noturno com iluminação sobre a placa

Legenda : $\quad$ D - Período Diurno

$\mathrm{N}$ - Período Noturno

NI - Período Noturno com iluminação sobre a placa

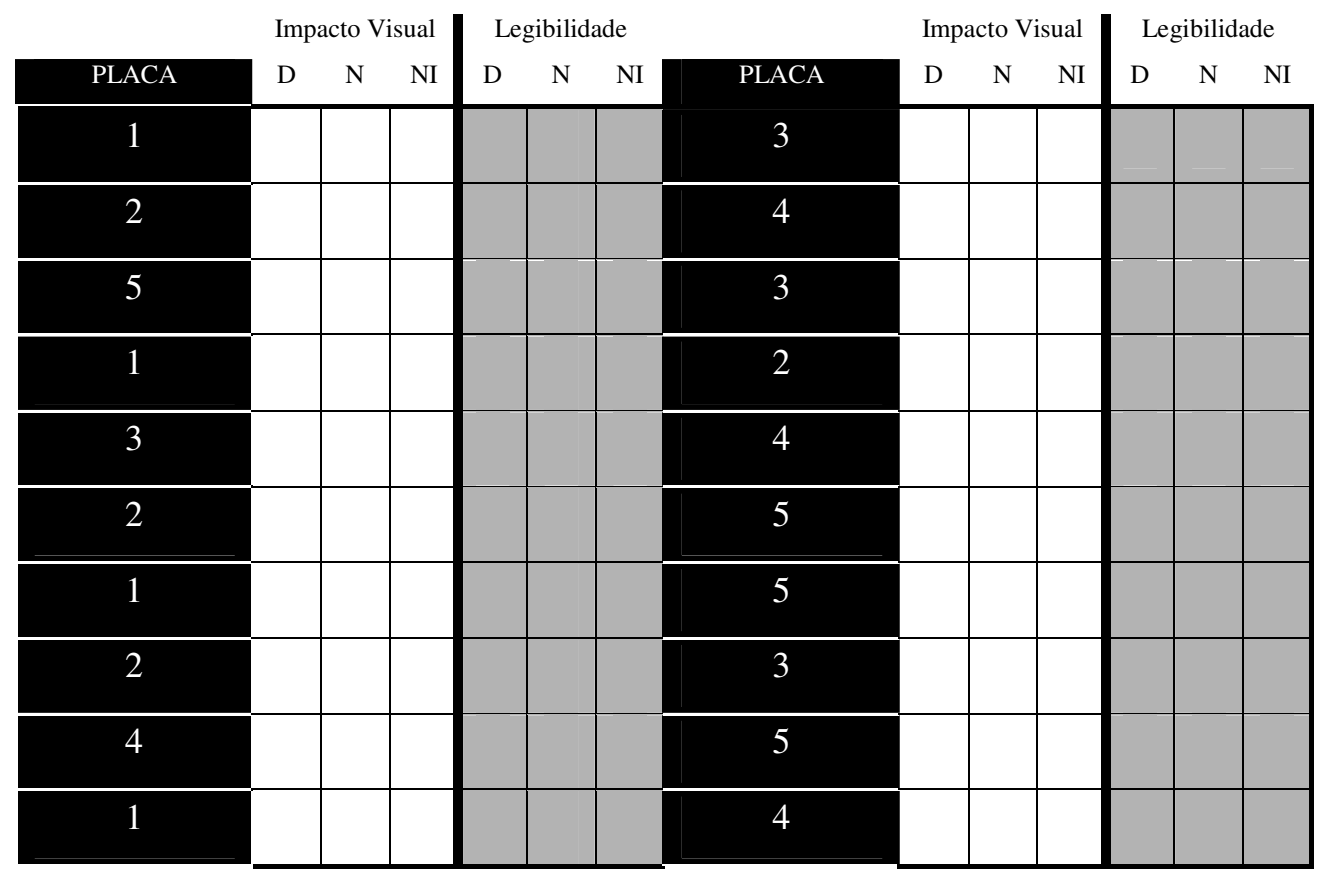




\section{ANEXO 2}

\section{EXPERIMENTO № $\mathbf{0}$}

\section{Avaliação da Conspicuidade e Legibilidade das Placas de Indicação de}

\section{Localidade}

\begin{tabular}{|c|c|c|c|c|}
\hline \multicolumn{5}{|l|}{ NOME: } \\
\hline \multicolumn{5}{|l|}{ Idade: } \\
\hline Sexo: & ( ) feminino & ( ) masculin & & \\
\hline $\begin{array}{l}\text { Grau de } \\
\text { Instrução: }\end{array}$ & $\begin{array}{c}\text { ( ) } \\
\text { pós-graduação }\end{array}$ & $\begin{array}{c}\text { ( ) } \\
\text { graduação }\end{array}$ & $\begin{array}{c}(\quad) \\
\text { ensino médio }\end{array}$ & $\begin{array}{l}\text { ( ) ensino } \\
\text { fundamental }\end{array}$ \\
\hline Motorista: & ( ) sim & ( ) não & & \\
\hline
\end{tabular}

Esta é uma pesquisa para verificar qual placa tem maior impacto visual (chama mais a atenção) e qual tem melhor legibilidade (é mais fácil de entender os símbolos e letras).

Será mostrado para você um conjunto de sinais, os quais você deverá comparar e escolher de acordo com a sua preferência.

Para que sua escolha seja computada, ela funcionará da seguinte maneira:

Com relação ao impacto visual:

1 - o sinal com maior impacto visual

0 - o sinal com menor impacto visual

Com relação à legibilidade:

1 - o sinal com melhor legibilidade

0 - o sinal com pior legibilidade 
Estes valores deverão ser marcados nas tabelas correspondentes aos sinais analisados.

Para cada conjunto de estímulos (sinais) é apresentada uma tabela que será preenchida à medida que estes forem mostrados.

Os seus dados pessoais não serão divulgados.

Obrigado pela sua contribuição.

Estímulos: Período Diuno (luz acesa) / Noturno (luz apagada) / Noturno com iluminação sobre a placa

Legenda: D - Período Diurno

$\mathrm{N}$ - Período Noturno

NI - Período Noturno com iluminação sobre a placa

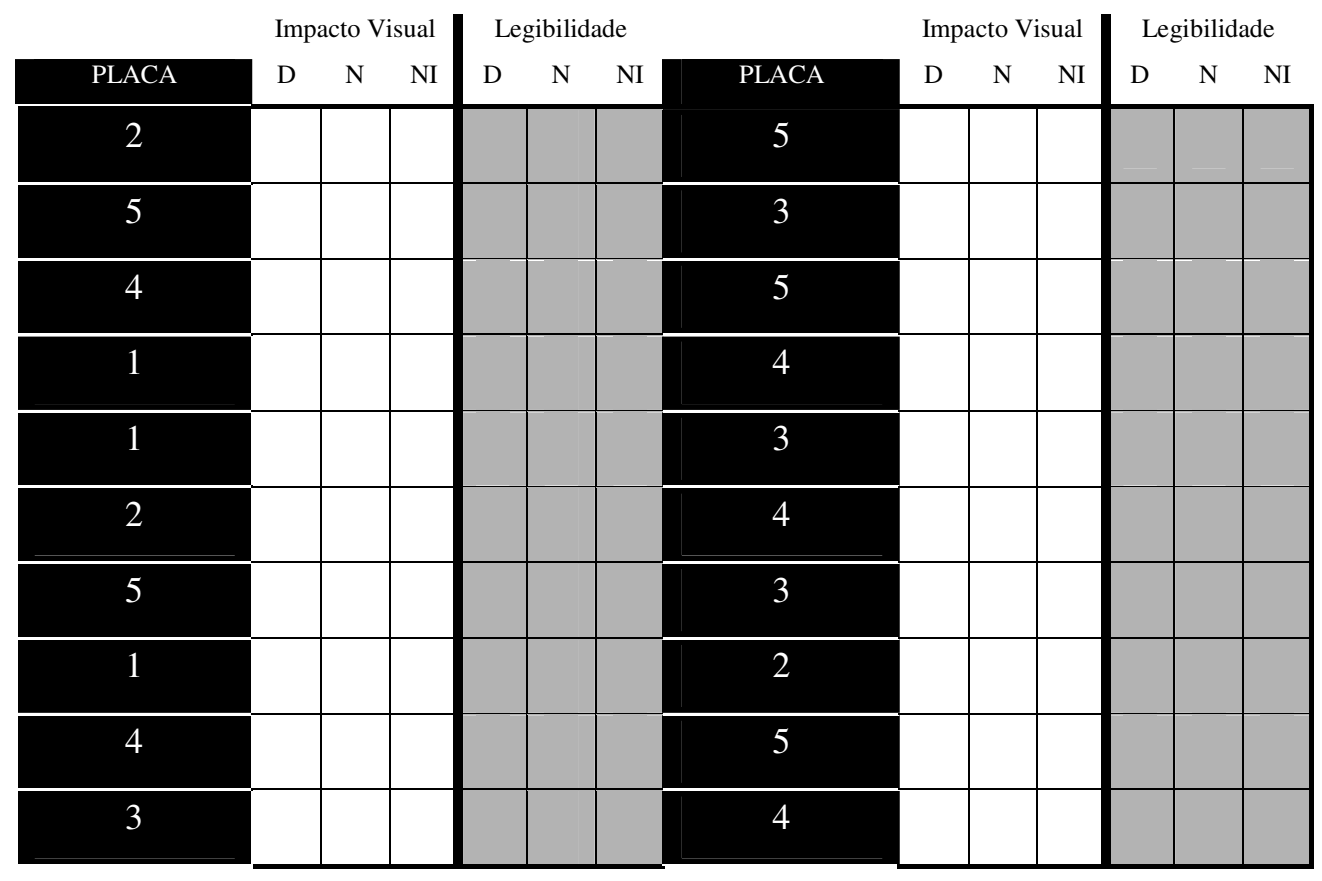




\section{ANEXO 3 \\ EXPERIMENTO № $\mathbf{3}$}

\section{Medida da Retrorrefletividade das Placas de Regulamentação e Indicativa de Localidade}

Todas as placas de regulamentação e indicativa de localidade utilizadas nos experimentos 1 e 2 foram submetidas a medições de retrorrefletividade.

Para realização deste experimento foram seguidas as diretrizes da ABNT NBR 15426 (Sinalização vertical viária - Avaliação da retrorrefletividade utilizando retrorrefletômetro portátil).

Placas de regulamentação (R19 - 20 km/h)

\begin{tabular}{|c|c|c|c|c|c|c|c|c|c|c|c|c|c|c|c|c|c|c|c|}
\hline \multirow[b]{2}{*}{ PLACA } & \multicolumn{6}{|c|}{ BRANCO (FUNDO) } & \multicolumn{6}{|c|}{ VERMELHO (ORLA) } & \multicolumn{7}{|c|}{ PRETO (CARACTERES) } \\
\hline & 1 & 2 & 3 & 4 & 5 & M & 1 & 2 & 3 & 4 & 5 & M & 1 & 2 & & & 4 & 5 & M \\
\hline 1 & & & & & & & & & & & & & . & - & & & - & - & - \\
\hline 2 & & & & & & & & & & & & & & & & & & & \\
\hline 3 & & & & & & & & & & & & & & 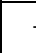 & & & - & - & - \\
\hline 4 & & & & & & & & & & & & & 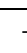 & 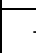 & & & - & - & - \\
\hline 5 & & & & & & & & & & & & & ( & & & & - & - & - \\
\hline
\end{tabular}

Placas de indicação de localidade (Palavra Fórum)

\begin{tabular}{|c|c|c|c|c|c|c|c|c|c|c|c|c|c|}
\multicolumn{7}{c|}{ AZUL (FUNDO) } \\
\multicolumn{1}{|c|}{ PLACA } & 1 & 2 & 3 & 4 & 5 & $\mathrm{M}$ & 1 & \multicolumn{1}{c|}{ BRANCO (LEGENDA) } \\
\hline 1 & & & & & & & & & & & & \\
\hline 2 & & & & & & & & & & & & \\
\hline 3 & & & & & & & & & & & & \\
\hline 4 & & & & & & & & & & & & \\
\hline 5 & & & & & & & & & & & & \\
\hline
\end{tabular}


